Historic, Archive Document

Do not assume content reflects current scientific knowledge, policies, or practices. 



\section{HOW TO ORDER BY MAIL}

Please use the Order Sheet enclosed with this Catalogue. Write your name and complete address plainly.

\section{ORDER FARLY}

Orders are booked in rotation as received. If a variety ordered is sold out we will substitute another variety of equal or higher value or return the amount to you. Please indicate by "yes" or "no" on order sheet in proper space, whether we may make substitution. Our stock of some varieties is limited and the first orders will get them.

\section{TERMS}

Remittance must accompany all orders as prices are based on cash with order. All bulbs ordered from this catalog sent prepaid to all points in United States and Canada. No charge for packing. Transportation extra to foreign countries.

\section{CANADIAN AGERCY}

All customers in Canada must send their orders to :

LYMAN W. COUSINS, 472 Tecumseh Ave.,

London, Ontario, Canada.

Add $25 \%$ to prices in this catalogue to cover customs duty. Import permits not necessary as the bulbs will be sent post paid from London, Ontario.

\section{TRADE DISCOUNTS}

Special lists will be sent to commercial growers, florists and nurserymen when application is made on printed stationery or business card enclosed.

\section{GUARANTET}

We guarantee all stock to be true to name and to be vigorous flowering size. We cannot guarantee results as the condition under which they are planted is a matter beyond our control. However, full cultural directions will be included with every shipment.

\section{TINIF OF SHIPMENT}

We begin to malke shipments about March 1st or as soon thereafter as the weather will permit.

\section{OUR IOCATION}

Our location is just east of Canandaigua on the Main Highway from Buffalo through Canandaigua to Geneva, Auburn, Syracuse and New York city. Thousands of tourists stop to view our plantings.

The Latch String hangs clear out into the middle of the road, and it will be our pleasure to make your personal acquaintance and show you what is now growing in an old Indian Garden.

\section{BANK REFERENCE}

If you should care to do so we invite you to refer to: The Canandaigua National Bank, or Ontario County Trust Co., both of Canandaigua, N. Y.

\section{OFFICERS OF THE COMPANY}

President, Wm. H. Purple

Treasurer, Fred R. Purple

Secretary, E. A. Purple Make all Checks and Money Orders payable to-

BILL'S GLAD FARIS, INC.

GLADIOLUS BILL, Mgr.

Canandaigua, New York 


\section{Complete Descriptive and Illustrated}
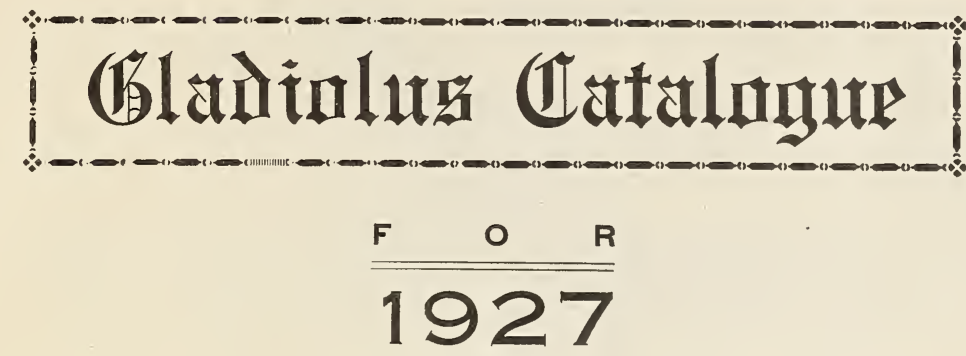

4

$$
\begin{array}{llllllll}
C & O & N & T & E & N & T & S \\
\hline
\end{array}
$$

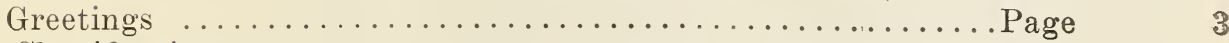

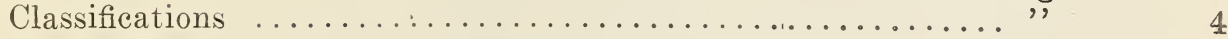

Chat with Beginners ......................, 7 to 8

General List ............................, 9 to 16

Connoisseur Section ......................., 17 to 31

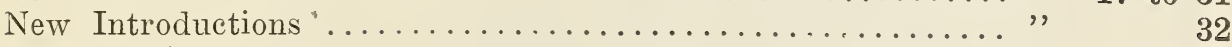

General List ..........................., 33 to 39

Special Discounts and Offers ..................., 40 to 41

How Cum "Gladiolus Bill" ...................." " $4 . \ldots \ldots$

Landscape Varieties ........................" 44

Books and Accessories ......................., 45

Garden Furniture ........................., 46 to 47

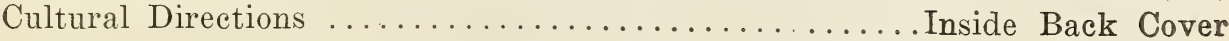

\section{PRYMIUM COUPON FOR FARIY ORDRRS.}

Early orders relieve the rush later on, enabling us to give you better service. Find below a schedule of the Premium bulbs, our selection, we will send you for orders received in February and March. Send this coupon with your order.
Amount of Your Order

\section{Premium for Eebruary}

$\dot{p} 2.00$

3.00

5. 00

10.00

20.00

50.00
\$. 10

.20

.35

.75

1.50

3.50

\section{Premium for March}

$\$ .05$ .10

.75

2.00

SPECHL YOTKCE.

The following changes since going to press.

ILLEY $\nabla$. BCWCE-All sold out.

BET'Y JOY-Iarge size sold out. Can furnish 3/4" at half price. DC GANNE DEIIHT-Yot more than one to a customer. 


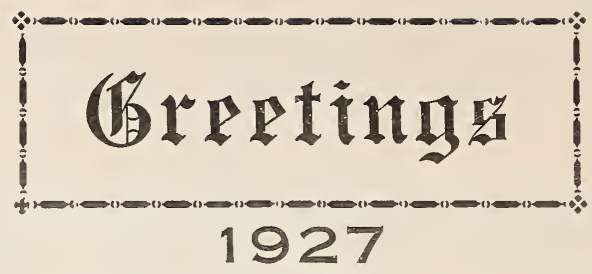

I hope you will read this page through, as I have something to say that wili interest you.

Right "off the bat" I want to thank those of you who have ordered bulbs from us so generously in 1926. Your orders more than equaled the total in cash value for the three previous years combined. Considering the reduced prices for 1926 you ordered three times as many bulbs as in 1925. The most pleasing part of it is that a large percentage of orders in 1926 were from those who had formerly purchased our bulbs. Evidently our bulbs are giving satisfaction.

For 1927 we are prepared to again take care of your increased orders. You will note there has been another material reduction in prices. We harvested a fine crop of bulbs from twenty-eight acres as against eighteen acres the previous year.

We have doubled the capacity of our storehouse (see cut on Page 48), and have installed machines for grading and cleaning the bulbs. This has increased the rapidity of handling as the bulbs came in from the fields so that they have passed through the drying rooms in $100 \%$ better condition than any other year.

I want to warn you, however, that many varieties are still in limited supply and the early orders will get them. This is especially true of those listed on the pink pages.

Just a word about those pink pages. We have two classes of customers. One class are desirous of having just a few Glads in their gardens and are entirely justified in wanting good reliable varieties at a moderate price. Last year perhaps you opened our catalog and about the first thing you saw near the head of the list was Allen V. Bunce priced at $\$ 1.50$ each. You said "Robber" and put it aside, overlooking the fact that some good varieties were priced at $\$ .05$ each. Now we don't enjoy being called such names, so we have listed for your convenience all the moderate priced ones on the white pages.

The other class of customers are the Glad Fans. You already have all the better known varieties and want something new and different. You cannot wait until the price comes down and everybody has them. The prices will come down in time and we are reducing them each year, but if we offered them too low you would buy all we have and we would never be able to propagate a large stock. So for you we have listed the extra fine rare varieties on the pink pages. Quality and rarity considered, I am sure you will find them priced reasonably.

The descriptions of "BILL'S ORIGINATIONS" are as accurate as I am able to make them. In most cases the colors are described to conform to Ridgway's Standard Color Chart. I want to be honest with you and tell you that I have never yet seen a Glad that I thought was perfect in every way. Chas. Gersdorff has become the recognized authority on the scoring of Glads, but he has never yet scored one $100 \%$. He has rated many of BILL'S ORIGINATIONS above $90 \%$ and he considers an $80 \%$ Glad in the Superlative Class.

I have told you the good points of each variety but have made no effort to tell you of the defects. If the defects are sufficient to make one undesirable, I simply do not list it at all.

A place is provided on our order sheet for you to answer "No" if you do not want us to make substitutions. We do not substitute as long as we have what you order, but after a variety is exhausted we put in a similar one of equal or greater value unless you say "No". The substitute will be correctly labeled.

You will find a number of special offers in this catalog. You will note each offer makes you a saving in price. Please don't ask us to make changes in these offers. It makes extra work in entering and packing your order.

You will note on Page 40 a scale of discounts you can use in making your own collections. Please don't apply the discounts to the special offers as we have already done so in making them up.

In April and May we will get the largest rush of orders and every one in a hurry. We can serve you better if we get a goodly portion of your orders in January, February and March. If you will just leave it to me, I will see that you get a nice present with urders over $\$ 2.00$ sent in March, a better one with February orders and still better with January orders. You will get an acknowledgment of January, February and 


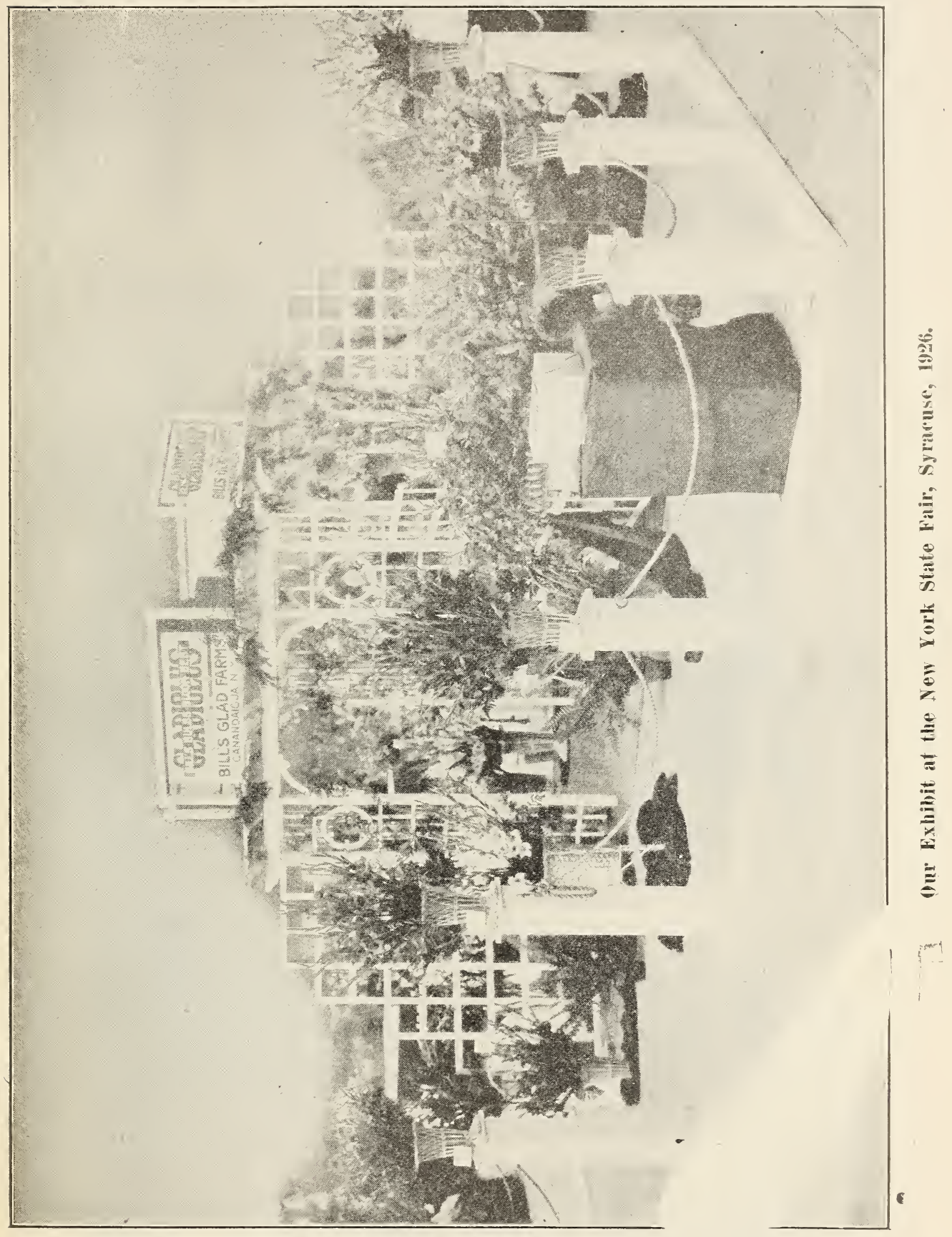


March orders promptly, but in April and May we may be too rushed to do so. Shipping will begin as early in March as the weather permits.

Will you please give us the names of your friends who have gardens. We do not buy lists of names, but if you will put them on the back of your oid ar sheet it will be a pleasure to slip something extra in with your order just to show our appreciation.

On Page 46 you will find a few items of Garden Furniture. This is manufactured in Canandaigua for us and we can guarantee it as to quality and workmanship. On Page 45 we list some of the best garden books available. Also a few accessories on Page 45.

I solicit your continued good will and patronage.

Yours most cordially,

GLADIOLUS BIL.

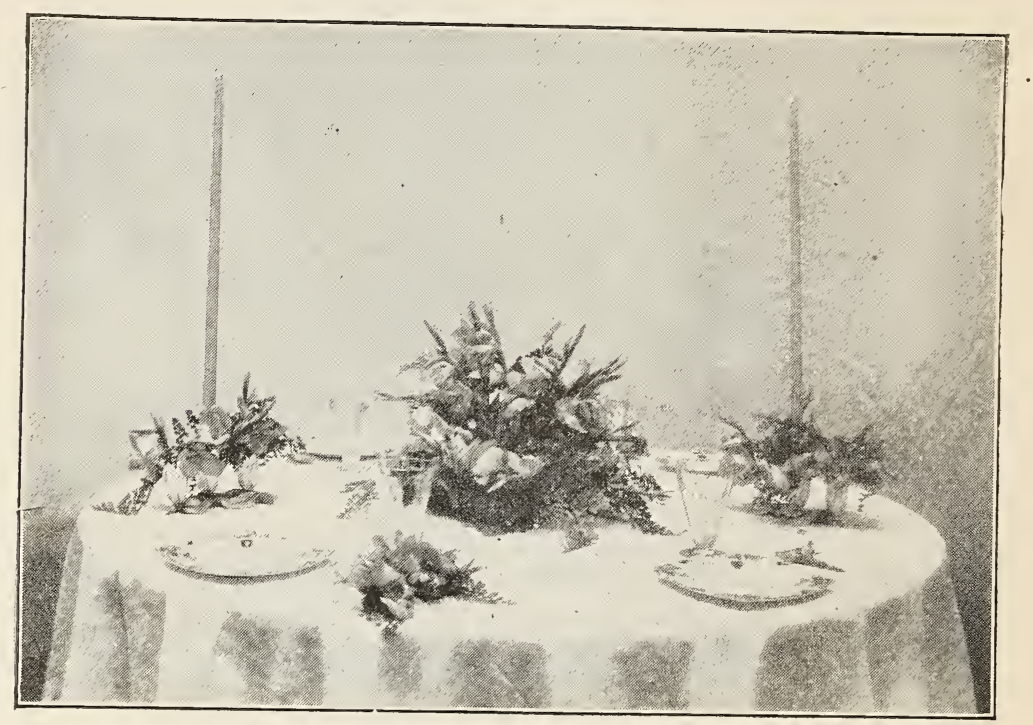

FIRST PRIZE-TABLE DECORATION.

At American Gladiolus Society Exhibit in Rochester, 1926.

(The variety used was Theda).

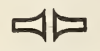

CLASSIFICATION OF GLADS.

The American Gladiolus Society has recognized and classified three distinct types of Gladiolus.

The Grandifloris or exhibition type with large flowers, sturdy growth, and many flowers open at a time facing one direction.

The Primulinus type with hooded flowers, of medium size, spaced well apart on graceful wiry stems.

The (P. G.) Primulinus Grandiflerus type combining the size and dignity of the Grandiflorus, with the grace and beauty of the Primulinus. This is the type destined to become most popular with those who know Glads.

The Society also recognizes certain variations of these three types which make them best adapted for commercial cut flower purposes as well as those with characteristics making them most valuable for landscape decoration.

In our descriptions you will find frequent reference to these types and our recommendation for the uses to which they are best adapied. 
THE EXHIBITS WINNING THESE CUPS WERE MADE UP ENTIRELY OF BILL'S ORIGINATIONS
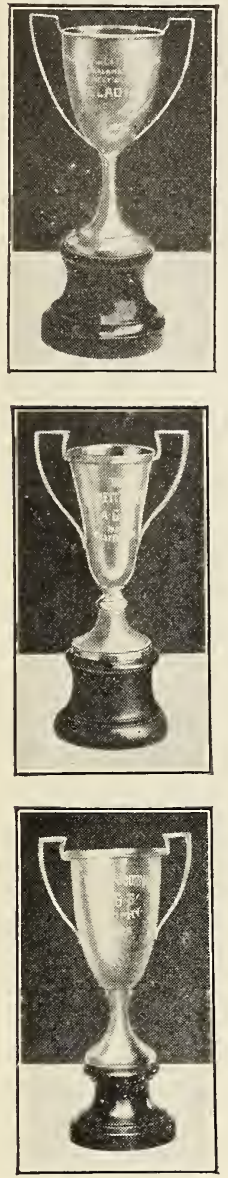

Times-Journal Loving Cup. Won for most artistic general display, Rochester, $\mathrm{N}$. Y., 1925.
President's Cup, won for the finest display, at New York City, 1924.
Winning one cup may have been an

Accident
Winning the second cup could have been $a$

\section{Coincidence}

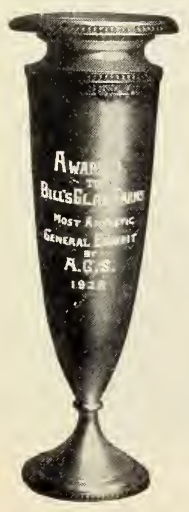

On winning the third cup, it becomes a Habit

Silver Cup. Won for most artistic general display, at Rochester, N. Y., 1926.

Winning four years in succession

$?$

\section{There's a Reason!}


BIII'S GIAD FARMS, Inc.

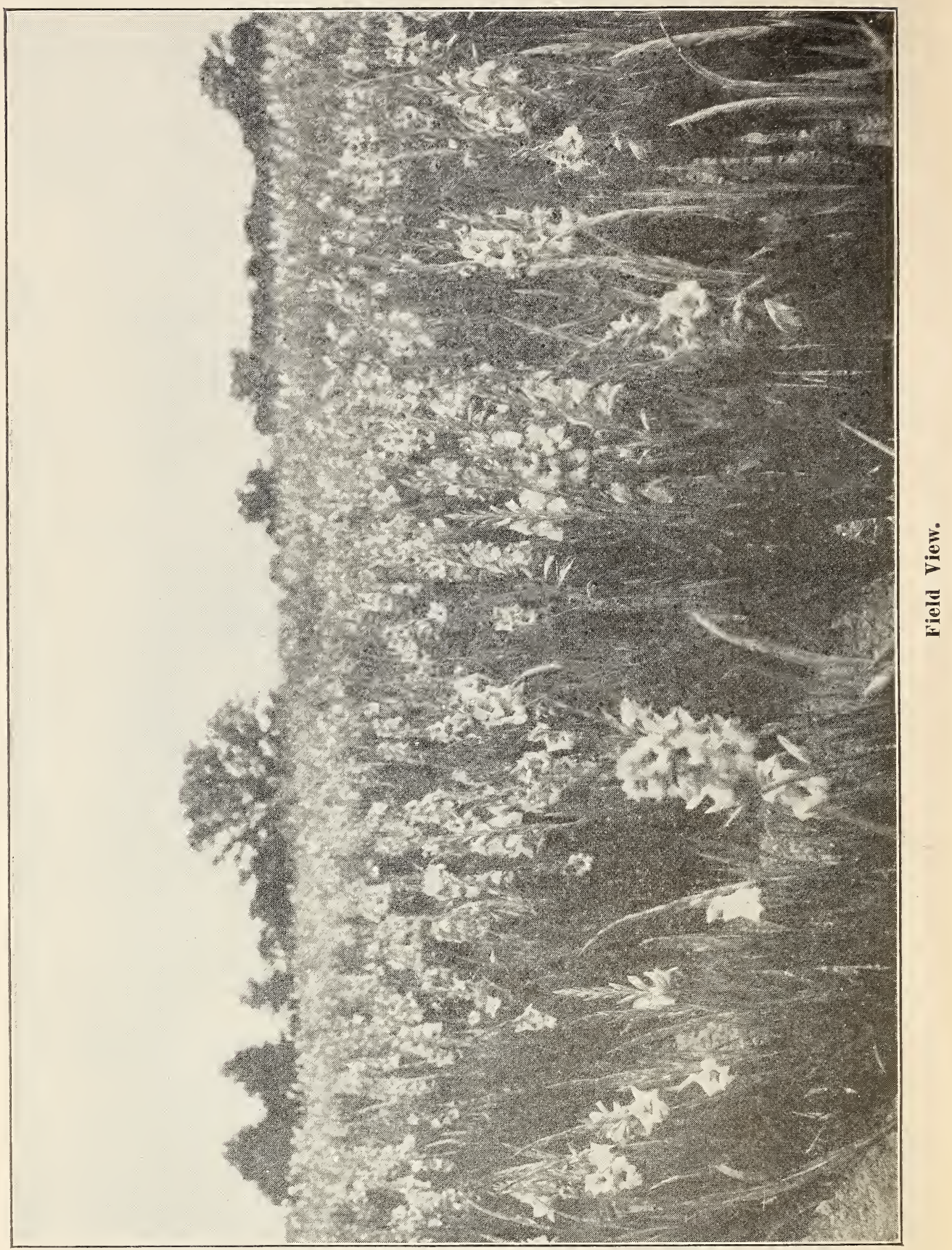




\section{A LITTLE CHAT WITH THE BEGINNER.}

Probably you know something of the beauty of the Gladiolus, and I am giving this little chat for the benefit of those who are just breaking into the game and whose practical knowledge is more or less meager.

Most of you already know what I shall have to say and may be able to say it better than I can.

\section{What does a Gladiolus look like?}

This is answered by just telling you to look at the pictures in this catalog.

\section{Does it grow from a seed?}

Sure thing, but you never buy seeds. Very few try to grow them from seeds because they do not come true to color. You buy bulbs, that will give you flowers the first summer.

\section{When do you buy them?}

You may place your order at any time and the bulbs are sent to you early in the spring. You plant them any time in the spring after the weather is settled. Watch your trees and when they start to put out new leaves it is time to plant your Glads.

\section{Where do you plant them?}

I once delivered a package of bulbs to a little lady who was in the habit of planting her potatoes, beans and such according to the old time almanac. Her remark was, "Shall I plant them in the moon?" For a minute I did not grasp her meaning, but when I "came up for air" replied, "No, just plant them in the earth." To answer the question seriously, I will tell you to plant them in the garden. By this I mean don't dig out a little square or long narrow space in the lawn and just stick them in. Don't plant them along the side of a building. They want light, air and sunshine from all directions to do their best. If you want them to do their worst just plant them near a maple or eim tree. Perhaps a little shade from the tree would not hurt them, but beware of the tree roots. Those tree roots are taking all the plant food from the soil twice as far as the spread of the branches. Your Glads would simply starve.

\section{How do you plant them?}

First of all plant them right side up. If you cannot tell which is the top, remove the husk from one bulb. It doe's not hurt them to remove the husk but don't let anyone tell you they will do better with the husk off. It is only a waste of time to do it. Now with the husk off see those circular rings on the bulbs. Just above each ring is an eye. The eye is where the top growth starts and the bulbs must be vianted with the eyes up.

You may plant them in rows or in solid masses. The easy way is to make a trench about five inches deep and place the bulbs on the bottom of the trench four inches apart. Then fill the trench level full with good soil. Put your rows far enough apart to allow for cultivation. If you want to walk between the rows have them three feet apart.

\section{Do they need rich soil?}

Yes and no. Good fertile soil will produce the finest blooms. If it is too rich with fresh manure it will burn them. Apply the manure the previous fall or use only a light top dressing after planting. Use Vigoro or sheep manure any time. Don't spade up a piece of old lawn or grass for your Glads. The top layer with the grass sod is filled with grubs, cut worms and wire worms. They are liable to attack your bulbs and plants. Better carry the sod away to a compost heap and put in new suil to replace it. Ask your druggist for a small piece of blue litmus paper. Bury this in your bed, then go and look at it in half an hour. If it shows signs of turning red sprinkle some lime on the surface and work it in before planting.

\section{What good are weeds?}

Weeds are a blessing to your garden, if you don't let them grow. If it were not for the weeds we would not cultivate our gardens enough. They just make us do it? Your plants have to grow by taking up. water from the soil with the plant foods in solution. If you don't culivate, a crust forms on the surface. The crust evaporates moisture from the soil faster than a loose surface would and then your plants go hungry and thirsty. The roots of those plants also have to be supplied with air, which can not reach them through the hard crust.

Do they need drainage?

Put a sponge in a pail of water and watch the air bubbles rise to the surface. 
When the bubbles stop you know the sponge is full of water and all the air is gone out of it. Then take the sponge out and let it drain. After a while your sponge is still wet but all the openings are filled with air again. Now remember that plant roots need air, and try to figure out how they are going to get it if water stands around your plants. You have the same condition as the sponge in the pail of water. If there is not natural drainage to your soil you should provide it.

Should they be watered?

Bet your life they should. But listen, the good Lord can do it better than you can. Save your watering until you know they need it badly then do a good job. When you have finished dig in to see if it has wet down six inches. If not, keep at it until it has. Don't sprinkle a little every evening. Better not water at all than do that. A little sprinkle only induces the roots to push up toward the surface and next day the hot sun kills them. Water deep, induce the roots to grow down, stir the surface next day to dry the top and let air in. Then let alone for a week or so.

May $I$ cut them for house decoration?

"Sure as shootin"" you may! Your plants will grow from 6 to 9 leaves before the buds and blooms appear. When the first one or two blooms are open on a stalk cut the stem out between the fifth and sixth leaves counting from the bottom. Cut the flower stem as long as possible but for the "loveomike" leave at least four good uninjured leaves on the plant. These are the bulb factory to make your new bulb. Put the cut spikes in water. A vase 8 to 10 inches deep nearly full of water. Give fresh water every day and cut one-half inch off the bottom of the stem and remove the wilted flowers. Oh! Lady, Lady, don't use the scissors for cutting. Get a sharp knife. There is a reason but I haven't room to tell it here. When the very top flowers bloom, cut the stems off short and put in a low bowl. This will be about 10 days after you first cut them in the garden. winter?

Do I leave the bulbs in the ground over

For goodness sakes no! At least not unless you want to buy new ones next year. If you buy all the bulbs you have room for this year, you will not need to buy more for several years. So don't let them freeze in the ground. Watch those trees again and when the leaves drop off it is time to dig your bulbs. Cut the tops off close to the bulbs as soon as you dig them. Put where they will dry for 2 or 3 weeks.

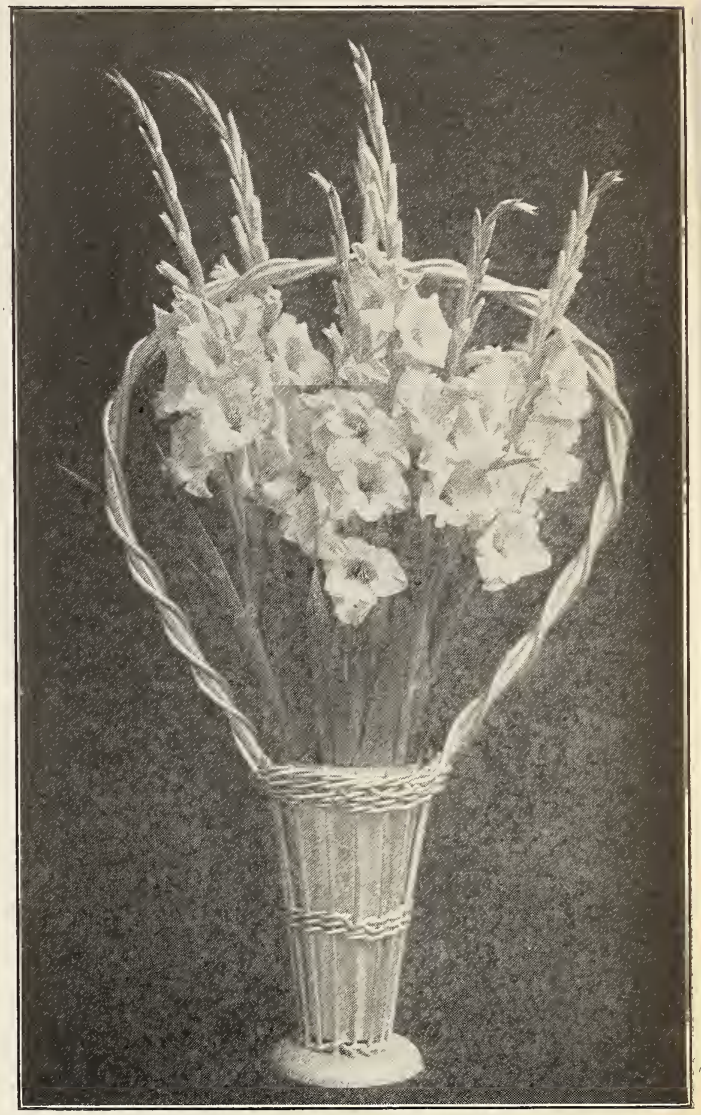

PATRICIA

(Descripton on page 28)

Then see how easy the old bulb you planted and the roots will come off the new bulbs. Throw the old bulbs away as they are worthless. Put the new bulbs where they will not freeze but not too hot and dry. If you have a frost proof fruit and potato cellar that is the best place. Look the bulbs over about Groundhog day, and if mouldy or roots starting, they are too damp. Give them ventilation. If the top sprouts are starting they are too warm. Put in a cooler place. Then look at them again early in March. You will have the new catalog by this time and if space permits I know you will want to order some more of "Bill's Bulbs".

Here's hoping you did not fall asleep reading this, but if you did I wish you luck when you wake up.

"GLAD. BILL." 


\section{(beneral Ifint}

In addition to our own productions we have included in the list the best and most popular moderate priced varieties now on the market. In nearly every instance we show the name of the originator in parenthesis following the name of the variety. Varieties that are strictly of the primulinus type with soft tone and wiry graceful stems, are indicated by the word (Prim.)

ADRIATIC-(Kunderd) Deep smoky wine blue, with blue and red throat. Extraordinary and beautiful. Try it! .............. Each 15e; 3 for 40c; Doz. \$1.50

AIRY FAIRIES-(Bill's Origination) Just that! Airy Fairies! There are two of them. A cream one and a pink cre. Exceedingly graceful and dainty Primulinus hybrids. Especially adapted for landscape planting. Gersdorff rating $S S$....... $\ldots \ldots \ldots \ldots \ldots \ldots \ldots \ldots \ldots \ldots \ldots \ldots \ldots \ldots \ldots \ldots \ldots$ Cream Each 10c; 3 for 25c; Doz. $\$ 1.00$ $\ldots \ldots \ldots \ldots \ldots \ldots \ldots \ldots \ldots \ldots \ldots \ldots \ldots \ldots$ Each 10c; 3 for 2oc; Doz. \$1.00

ALBI0N-(Kunderd) (Prim.) Delicate soft salmon rose pink. Just the thing for table and house decoration; also a wonderful variety for landscape work as it will always stand erect if properly planted. Medium size bulbs for mass planting $\$ 2.00$ per $100 \ldots \ldots \ldots$......Each 5e; 3 for 15e; Doz. 50c; per 100, $\$ 3.00$

ALICE TIPLADY-(Kunderd) (Prim.) One of the best varieties yet developed in the Primulinus. Soft orange saffron shade. Extra fine! Medium size bulbs for landscape planting $\$ 3.50$ per $100 \ldots \ldots \ldots \ldots \ldots \ldots$. Each 10c; 3 for 25c; Doz. $\$ 1.00$

ALLEN V. BUNCE-(Bill's Origination) See Page 18.

ALMA MATER-(Bill's Origination) See Page 18.

ALTAIR-(Kunderd) (Prim.) Extra tall, finest salmon saffron. An entirely new shade and very beautiful. Early! ................. Each 10c; 3 for 25c; Doz. \$1.00

AMERICA-Very light lavender pink. Usually referred to as an orchid shade. The most popular variety in existence ......Each 5̌c; 3 for 15e; Doz, 50c; per 100, \$3.00

ANAMOSA-(Kunderd) (Prim.) Very large, extra tall, finest orange salmon with many

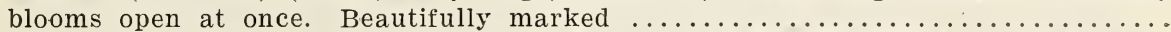
$\ldots \ldots \ldots \ldots \ldots \ldots \ldots \ldots \ldots \ldots \ldots \ldots$ Each 10e; 3 for 250 ; Doz. $\$ 1.00$; per 100, $\$ 5.00$

ANG0LA-(Kunderd) (Prim.) A fine tall very early salmon pink. Fine for house decoration ....................Each óc; 3 for 15e; Doz. 50c; per 100, $\$ 3.00$

ARABY-(Bill's Origination) See' page 32.

ARBITRATION-(Bill's Origination) Salmon pink semi-primulinus with large florets well opened. Extra strong vigorous grower ....Each 20c; 3 ior 50c; Doz, \$2.00

ARIEL_(Bill's Origination) Ariel-“"The Fa:ry Sprite" is one of those airy graceful Primulinus hybrids most effectiveiy used for table decorations and fancy baskets. A good strong grower with creamy white flowers. In spite of the rather tall growth it stands up well and makes a thick row of foliage and blooms. We recommend it strongly for landscape plantings and offer medium size bulbs at $\$ 6.00$ per $100 \ldots \ldots \ldots \ldots \ldots \ldots \ldots \ldots$ Each 20e; 3 for 50e; Doz. $\$ 2.00$; per 100, $\$ 10.00$

ARISTOTLE-(Bill's Origination) (Prim.) Very tall, straight, vigorous. Light

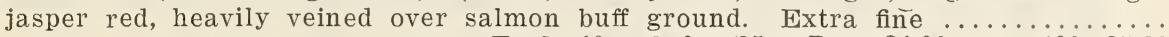
$\ldots \ldots \ldots \ldots \ldots \ldots \ldots \ldots \ldots \ldots \ldots$ Each 10c; $\mathbf{3}$ for 25e; Doz. $\$ 1.00$; per 100, $\$ 5.00$

BARON HULOT-Not very large', but that violet blue color at moderate price. Order a dozen or more ..........................Each 10c; 3 for 20气 ; Doz. \$1.00 
BILL'S GLAD FARIIS, Inc.
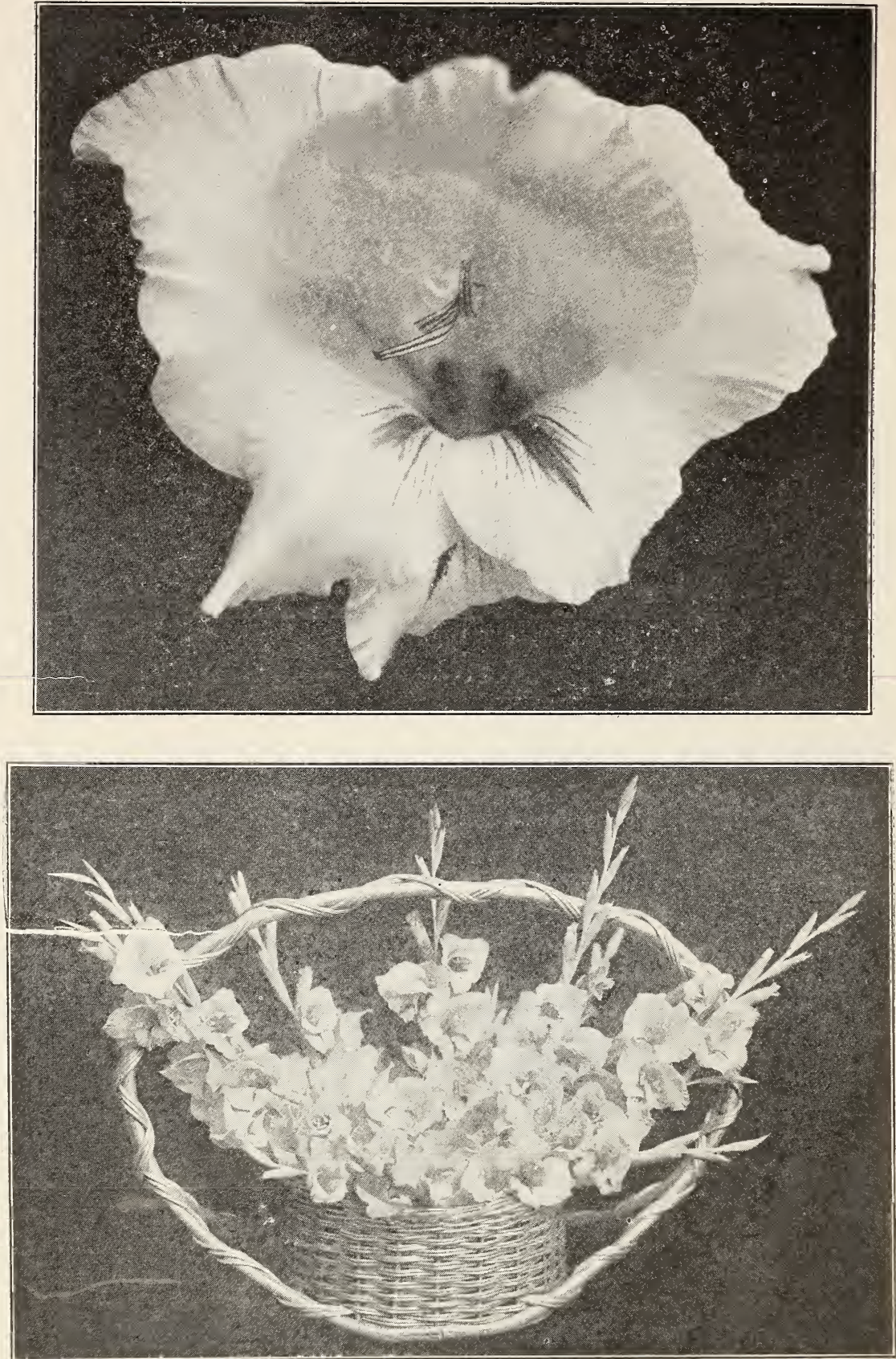

CAMEO

CAME0-(Bill's Origination) One of the finest Primulinus hybrids yet produced. The soft dainty shades seen in an expensive Cameo. Upper petals LaFrance pink over cream ground with deeper shade on back of petals. The lower petals are Martius yellow shaded off to cream white at tips with a delicate but distinct feather of spinel red. Very tall, straight, early, hooded and winged and slightly ruffled. Rated $94 \%$ by Gersdorff ........Each 20c; 3 for 50c; Doz. $\$ 2.00 ;$ per 100, $\$ 10.00$ 
BEATRICE-(Bill's Origination) Se' Page 18.

BETTY BLYCE-(Bill's Origination) See Page 18.

BETTY JOY_(Bill's Origination) See Page 19.

BLUE ISLE-(Kunderd) After trying many lilac blues, we kept this one as being the beist. It gives just the touch of color you want in your garden in mid-summer.... $\ldots \ldots \ldots \ldots \ldots \ldots \ldots \ldots \ldots \ldots \ldots . . \ldots a c h 25 c ; 3$ for $65 \mathrm{c} ; \mathrm{Doz}_{0} \$ 2.50 ;$ per $100,1 \$ 10.00$

BOUYCIYG BET-(Bill's Origination) See Page 32.

BREAK 0'DAY - (Bill's Origination) See Page 20.

BROADELBIN-(Bill's Origination) See Page 32.

BUDDY-(Bill's Origination) (Prim.) LaFrance pink, flaked geranium pink. Throat of martius yellow with lines of Pomegranate purple. Tall and earrly ........... $\ldots . \ldots \ldots \ldots \ldots \ldots \ldots \ldots \ldots \ldots \ldots . . . \ldots a c h 15 c ; 3$ for $40 \mathrm{c} ;$ Doz. $\$ 1.50 ;$ per $100, \$ 7.50$

CANANDAIGUA RED-(Bill's Origination) See Page 21.

CAPTAIN JINKS-(Bill's Origination) Geranium pink with pinard yellow throat blotches and line of spectrum red on lower petals. Extra strong grower and early bloomer ..................................... 20c; 3 for 50c; Doz. $\$ 2.00$

CARMINE KID-(Bill's Origination) Medium size flowers of beautiful rich carmine with creamy stippling in the throat. Several flowers open at a time. Very prolific and should be planted in quantities for landscape effect. Medium size bulbs for landscape work at $\$ 2.00$ per $100 \ldots \ldots \ldots \ldots \ldots$. Each 5c; 3 for 15c; Doz. 50c

CHAMELEON-(Bill's Origination) See Page 21.

CHICADEE-(Bill's Origination) Very dainty and airy. An extra early variety of merit. Eosine pink with light yellow blotches on lower petals. Slightly hooded and winged with side petals reflexed. Gersdorff rates this $90.7 \ldots \ldots \ldots \ldots \ldots$

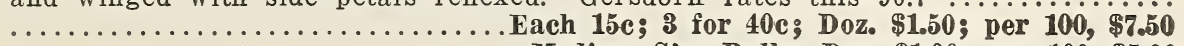

Medium Size Bulbs, Doz. $\$ 1.00$; per 100, $\$ 5.00$

CHIEFTAIN-(Bill's Origination) See Page 32.

CLEOPATRA-(Bill's Origination) See Page 22.

CLI0-(Bill's Origination) An oddity worth while for those wanting something different. A big clown. Very large, wide open, light rose with a funny face .......

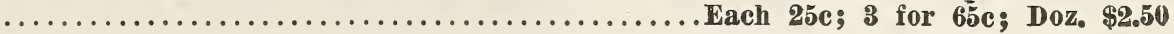

CLYDESDALE-(Bill's Origination) (New 1927) This is one of the wine red varieties, tall grower, slender stem, with large graceful blooms. In the throat of the flowers there is a distinct stippling of cream ........... Each 25c; 3 for 65c; Doz. \$2.50

COLLEEN-(Bill's Origination) A fine delicate, light airy type of flower. Light.rose shaded to nearly white, deep in throat. The lower petals have strong central lines of dahlia carmine drawn across a zone of very light yellow. Quite early ....

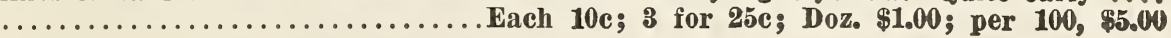

COPPERHEAD-(Bill's Origination) (Prim.) Tall, straight, slender stalks of medium size flowers, hooded, winged and frilled. Distinct copper tint, being an entirely new shade. The general color is coral red shaded to Antimony yellow in the throat with heavy feather of brownish red ........ Each 10c; 3 for 25 c; Doz. $\$ 1.00$

"Dear Bill:- You can tell the cock-eyed Universe that you know your stuff when it comes to gladdening the glad world with glad Glads.

"I had bully good luck with your stock this season. Particularly was this true of Cleopatra and Opalescent. But I consider your 'Gift Box Collections' the very best bargain I struck this year. Every bulb in the box was an ace and I'm going to put in an order for some more of them for next year."

W. S. (Oregon.) 
CREATORE-(Bill's Origination) See Page 23.

CROWN OF GOLD-(Bill's Origination) See Page 23.

DANTE-(Bill's Origination) (Prim.) Entirely new in appearance and texture. The general tone is light mallow purple. This color laid over a cream ground in thick veins, giving the effect of delicate crepe tissue. A moderate size Prim, rather tall grower and usually branched. We strongly recommend this as being a very desirable variety for large mass plantings in landscape designs

Each 15c; 3 for 40c; Doz. $\$ 1.50$; per 100, $\$ 7.50$ Medium size bulbs, $\$ 1.00$; per $100, \$ 5.00$

DARDANELLA-(Bill's Origination) See Page 24.

DEBUTANTE-(Bill's Origination) Se' Page 23.

DEWDR0P - (Bill's Origination) Early Primulinus Hybrid of Marguerite yellow with striking throat lines of amaranth purple. Many flowers open at a time. Only partly hooded. Very strong and prolific. Excellent for landscape plantings ......

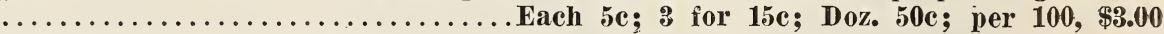

DIXIE MAID-(Bill's Origination) Pale Hermosa pink flaked Begonia rose. Small Picric yellow throat blotch. Very dainty and beautiful. Early! ...............

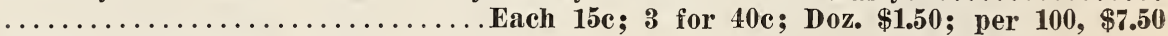

DU GANNE DELIGHT-(Bill's Origination) See Page 24.

EARLY LADDIE-(Bill's Origination) See' Page 24.

EARLY LASSIE-(Bill's Origination) See Page 24.

EARLY ONE-(Bill's Origination) (New 1925) One of the earliest to flower and valuable as an early market variety. Subdued Begonia rose, amber yellow throat stippled with Aster purple. Flowers wide open with reflexed petals. ...........

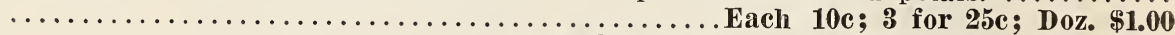

Medium size bulbs, Doz. 75c; per 100, $\$ 3.00$

ECH0-(Bill's Origination) See Page 32.

ELAINE-(Bill's Origination) See description with Lancelot on Page 25.

ELEGANT BEAUTY-(Kunderd) (Prim.) Large ruffled salmon blooms. Excellent for cutting ...................Each 10c; 3 for 25c; Doz. $\$ 1.00$; per 100, $\$ 5.00$

ELFIN-(Bill's Origination) (Prim.) General tone is saffron pink, melting away to Maize yellow in the throat with delicate feather of Nopal red. A dinner table decoration of Elfin at the A. G. S. Show in Rochester in 1923 constituted one of the most effective displays at the show and caused most favorable comment ....

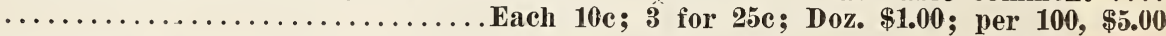

ETENDARD-A French variety of great beauty. Large cream flowers with velvety dark red blotch in center, giving the appearance of huge butterflies .............

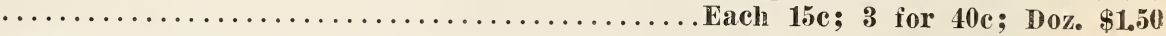

EVANGELINE-(Bill's Origination) See Page 25.

EVELYN KIRTLAND-(Austin) Very tall, straight and graceful shell pink, shading to rosy pink at the edges. Fine $! \ldots \ldots \ldots \ldots \ldots \ldots$ Each 10c; 3 for 25c; Doz. $\$ 1.00$

FASTIDIOUS-(Bill's Origination) See Page 25.

FLEETWOOD-(Bill's Origination) See Page 32.

FLORAL TRIBUTE-(Bill's Origination) (New 1925) One of the varieties which won the Harry L. Davis Cup at Rochester in 1923. A large cream yellow Primulinus. Very strong grower with tall straight spikes. Most attractive in large fancy baskets .....................Each 25c; 3 for 65c; Doz. $\$ 2.50$; per 100, $\$ 12.00$ 


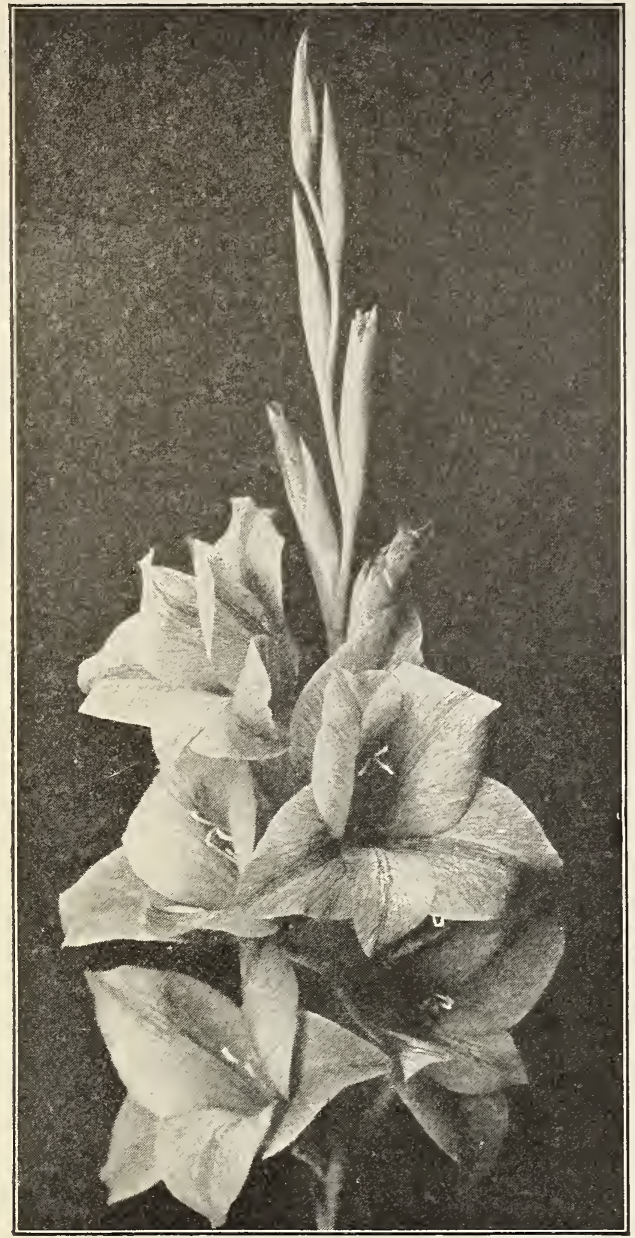

FRECKLES

FRECKLES - (Bill's Origination) (Prim.) Reminds one of the proverbial freckle faced boy and just as full of pep. The color is practically an orange salmon with a paisley effect. Large open flowers and a sure bloomer. Always stands erect. Always good regardless of weather conditions. One of the best for large landscape plantings. Me'dium size bulbs, $\$ 2.00$ per $100 \ldots \ldots \ldots \ldots$ Each 5c; 3 for 15c; Doz. 50c; per $100, \$ 3.00$

FLORENTIYA - (Bill's Origination) Tall and strong with many extra large flowers open at once. Soft pink with maroon silver throat. Extra fine! Rated $96 \%$ by Gersdorff $\ldots \ldots \ldots \ldots \ldots \ldots \ldots \ldots$. ..Each 25c; 3 for 65c; Doz. $\$ 2.50$ FORT SUHTER-(Bill's Origination) See Page' 32.

GALAXY - (Bill's Origination) See Page 25.

GEORGLANNA-(Bill's Origination) Extra good late bloomer. Light Eosine pink with delicate throat spinel red. Large flowers of

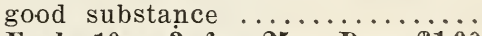
Each 10c; 3 for 25c; Doz. $\$ 1.00$ GLADDIE BOY - (Bill's Origination) See Page 26.

GLORIA-(Bill's Origination) Extra tall, strong and straight. Rose doree shaded to Geranium pink in the throat. A light yellow zone on the lower petals. Extra fine for florist trade ..Each 10c; 3 for $25 c$; Doz. $\$ 1.00$; per $100, \$ 5.00$. Medium size bulbs, Doz. 75c; per $100, \$ 3.50$

GOLD DROP-(Kunderd) (Ruffled Prim.) Extra large pure yellow with beautiful red line on lower petals. Ruffled and grand ................................... 10c; 3 for 25c; Doz. $\$ 1.00$

GOLDEY MAID-(Bill's Origination) See Page 25.

GREGOR YEYDEL-(Bill's Origination) (Prim.) A new shade in Gladiolus. Almost a pure self color of Rhodamine purple lightly flaked Aster purple. A distinct style is given by the petals being nearly always arranged in reverse form instead of the standard arrangement .... Each 20c; 3 for 50c; Doz. $\$ 2.00$; per $100, \$ 10.00$

HALCYON-(Bill's Origination) See Page 25.

HARVEST MOON-(Bill's Origination) See Page 25.

HERADA-(Austin) A glistening clear lavender, known as Mauve shade. This has become a favorite. The best of the Austin Originations. No collection complete

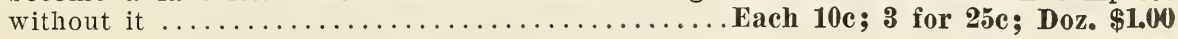

HILDA-(Bill's Origination) (New 1926) A big husky Geranium pink with light throat ....................................... 25c; 3 for 65c; Doz. \$2.50 
HIS MAJESTY-(Bill's Origination) (Prim.) I almost named this "His Satanic Majesty," as that is what the color suggests. Very rich, deep velvet scarlet ..... ................................................. 10c; 3 for 25c; Doz. $\$ 1.00$

HOPEWELL WHITE-(Bill's Origination) See Page 25.

HUMDINGER-(Bill's Origination) See Page 25.

IRENE-(Bill's Origination) Large open flowers of Begonia rose with beautiful large velvety blotches of deep carmine. Striking flower. Rated $91 \%$ by Gersdorff .... ................................................... 15c; 3 for 40c; Doz. $\$ 1.50$

JACOBA VAN BEYREN-(Heemskerk) A recent importation of merit. Extraordinary violet self color, well placed on tall spike. A winner at the A. G. S. Show in $1925 \ldots \ldots \ldots \ldots \ldots \ldots \ldots \ldots \ldots \ldots \ldots \ldots \ldots \ldots$ Each 50c; 3 for $\$ 1.25 ;$ Doz. $\$ 5.00$

JASPER-(Bill's Origination) A sturdy, strong grower with large well placed flowers of Jasper red with waved petals. Very heavy distinct feather of velvety Amaranth purple spread over beautiful light zones of clear yellow. Early, prolific. Rated $93 \%$ Exhibition by Gersdorff .................Each 20c; 3 for 50c; Doz. $\$ 2.00$

JENNY LIND-(Hoeg) Shrimp pink deepening to Geranium pink at tips of petals. Ruffled and petals reflexed at tips. Compact spike makes it one of the best for floral work $. . \ldots \ldots \ldots \ldots \ldots \ldots \ldots \ldots \ldots \ldots . . . \ldots a c h$ 25c; 3 for 65c; Doz. $\$ 2.50$

KING MIDAS-(Bill's Origination) See Page 25.

LANCELOT-(Bill's Origination) See Page 25.

LA ROSE-(Bill's Origination) See Page 27.

LITTLE BILL_(Bill's Origination) "Little, but Oh! My!" Just the daintiest little Prim you ever saw. Perfect open type, slender stem with soft creamy florets. Wonderful for use in a rose bud vase. Each 10c; 3 for 25c; Doz. $\$ 1.00$; per 100, $\$ 5.00$

LOS ANGELES-(Houdyshel) A new LaFrance Pink produced on the Pacific Coast. It is of the Primulinus Grandiflorus type, strong growth and rated 93 to 96. Excellent for cut flowers and extra fine for landscape decoration. Lateral branches are produced so freely that several cuttings may be made from one spike. Known as the "Cut and come again" Glad ............. Each 50c; 3 for \$1.25; Doz. \$5.00

LOVERA-(Bill's Origination) Beautiful soft Shrimp pink with Picric yellow throat. Dainty carmine lines on lower petals. Each 10c; 3 for 25 ; Doz. $\$ 1.00 ;$ per 100, $\$ 5.00$

MANDALAY_(Bill's Origination) See Page 27.

MARCELLA-(Bill's Origination) See Page 27.

MARY PICKFORD-(Kunderd) Wonderful creamy white with handsome heavy spikes showing many flowers open at once. Admired by everyone and received special award of merit ...............Each 15c; 3 for $40 \mathrm{c}$; Doz. $\$ 1.50$; per $100, \$ 7.50$

MATADOR-(Bill's Origination) See Page 27.

MATTHEW CRAWFORD-(Kunderd) Creamy pink, very massive and showy .....

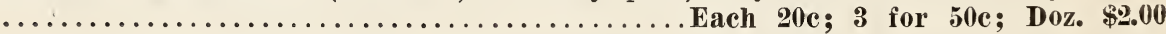

MAUD MULLER - (Bill's Origination) (New 1926) An orange and yellow Prim that everyone stopped to admire in our fields. Medium height and even growth ......

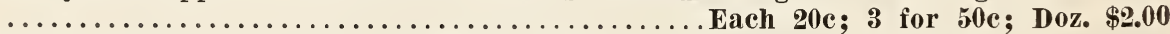

MILADY - (Bill's Origination) (Ruffled) Extra tall, strong ruffled variety of creamy white. Naples yellow throat with heavy Amaranth purple feather. Very strong, prolific grower and usually branched. Rated $98 \%$ as a commercial variety by Gersdorff...$\ldots \ldots \ldots \ldots \ldots \ldots \ldots$. Each $25 \mathrm{c}$; 3 for 65c; Doz. $\$ 2.50$; per 100, $\$ 12.00$ Medium size bulbs, Doz. $\$ 1.50$; per $100, \$ \$ .00$ 


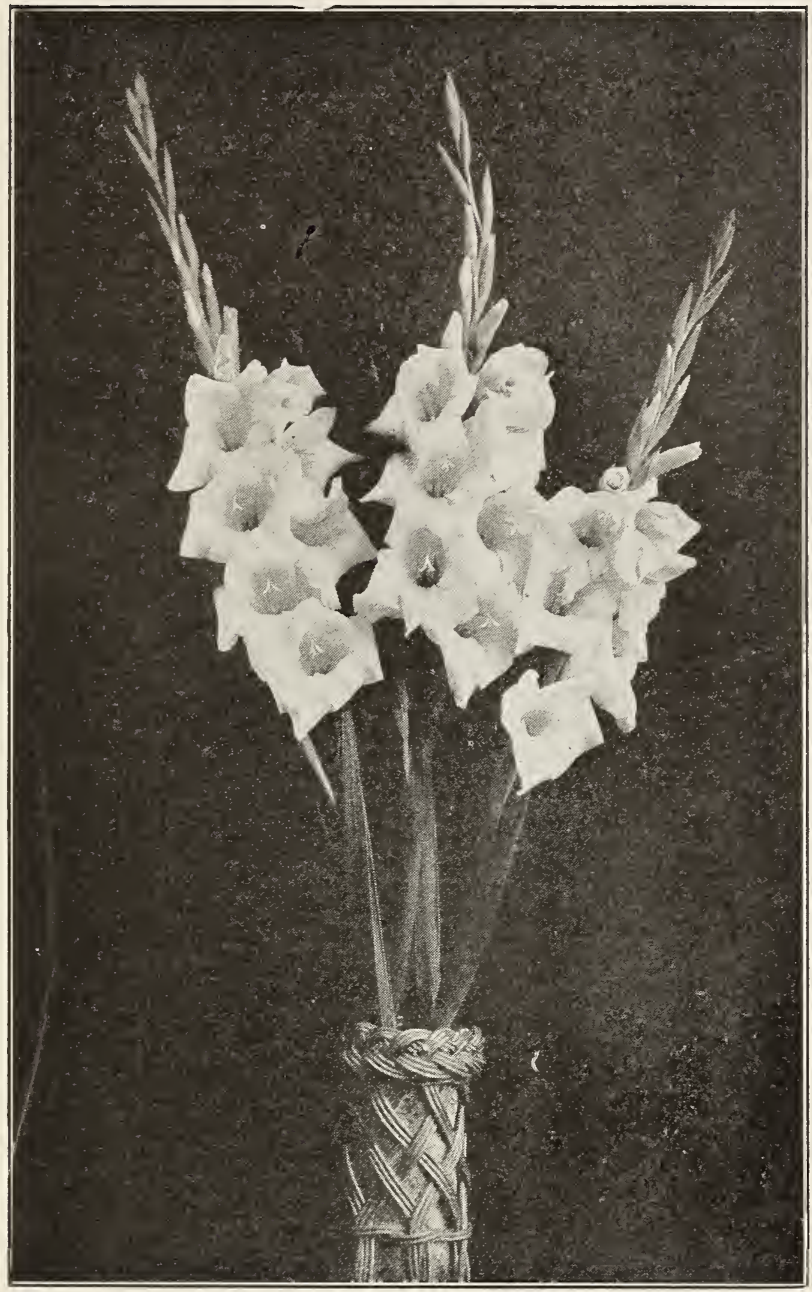

\section{LUCETTE}

LUCETTE-(Bill's Origination) As sten growing in the fields it appears to be absolutely pure white but backs of petals carry a trace of Phlox pink which imparts an alluring orchid sheen to the flowers. Lower petals have a dainty subdued feather of wonderfully soft Phlox pink. As a commercial white, it is ideal in color, and form. Also well adapted for mass planting in landscape work. Extra good as a forcing white ............Each 15c; 3 for $40 \mathrm{c}$; Doz. $\$ 1.50$; per $100, \$ 6.00$

Medium size bulbs, Doz. $\$ 1.00$; per $100, \$ 4.00$

“All of your originations including Break O' Day that we bought last Spring did fine. Lucette was splendid.

"Milady deserves more attention or rather publicity than sne is getting. She took well in all our exhibits and in our show garden." K. R. CLENDENING, Iowa.

"Had some wonderful spikes of JASPER but the finest thing of all was FASTIDIOUS." DR. F. E. BENNETT, St. Thomas, Ont., Canada. 
MAHOWET-(Bill's Origination) (New 1926) A novelty of bright Peach red, heavily flaked with bordeaux at the tips. Large loose spike and attractive. The kind

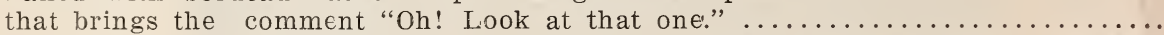
Each 25c; 3 for 65c; Doz. $\$ 2.50$

MONA LIZA-(Kunderd) (Ruffled) Magnificent pale soft pink. Many open at a time. Should be in every collection ................ Each 20c; 3 for 50c; Doz. $\$ 2.00$

MYROY_-(Bill's Origination) See Page 27.

NACO0ILE-(Bill's Origination) See Page 27.

NIGHT BIRD-(Bill's Origination) See Page 27.

1910 RoSE-(Kunderd) Pure rose shade with white central lines on lower petals. An extra fine variety for florists. Very popular in Chicago and other Western markets. Medium size bulbs for landscape plantings, $\$ 3.50$ per $1.00 \ldots \ldots \ldots$

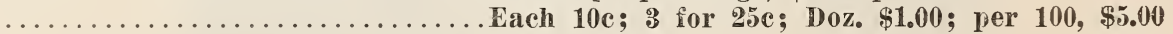

1925 ROSE-(Bill's Origination) See Page 27.

NOKOMIS-(Bill's Origination) (Ruffled) Colors are suggestive of the American Indian race. Hence the name Nokomis. Flame' scarlet flaked mahogany at tips. Lemon yellow medial lines. Strong, large ruffled flowers and an entirely new combination. Rated $92 \%$ by Gersdorff. Prize winner for best orange at A. G. S.

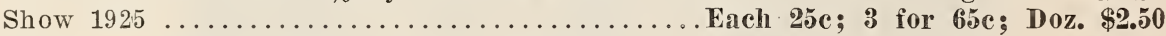

NORWALK-(Bill's Origination) See Page 27.

OBERLIY_-(Bill's Origination) (New 1925) Very large Geranium pink with throat stippled Pomegranate purple. Large cream zone. Petals extra heavy and substantial. Rated 87.8 by Gersdorff .............. Each 20c; 3 for 50c; Doz. $\$ 2.00$

OH! BOY !-(Bill's Origination) See Page 27.

OLYMPIAD_(Bill's Origination) See Page 27.

OPALESCEYT-(Bill's Origination) See Page 28.

ORIFLANE-(Bill's Origination) (New 1925) Large brilliant Orange pink. One of

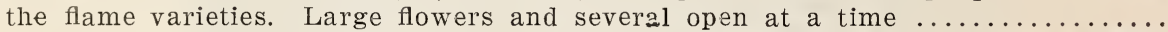

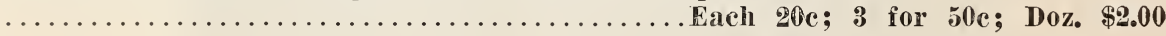

PARADER-(Bill's Origination) Very soft Begonia rose flake'd scarlet red. Heavy scarlet throat blotch bordered with zone of Pinard yellow. Strong straight spikes with several flowers open at a time. We have excellent reports from those who purchased it last season ..........Each 20c; 3 for 50c; Doz. $\$ 2.00 ;$ per 100, $\$ 10.00$

PATRICIA-(Bill's Origination) See Page 28.

PICCADILLY-(Bill's Origination) See Page 30.

PINEHURST-(Bill's Origination) (Ne'w 1925) Sulphur yellow with pale greenish yellow throat. Very tall, strong grower with 18 or 20 buds on a stalk. Usually opens 6 to 8 flowers at a time. Good size blooms well placed facing regularly. Commercial rating $89.3 \ldots . .$. Each $25 \mathrm{c}$; $\$$ for $65 \mathrm{c}$; Doz. $\$ 2.50$; per 100, $\$ 12.00$

PINK PRIDE-(Bill's Origination) See Page 28.

PIPPIN-(Bill's Origination) Soft plush Eosine pink flowers of large size on tall straight stems. Neat feather and stippling of Eugenia Red on cream throat. Strong grower and a wonderful flower. One of the best and most prolific. Excellent for market cut flowers ........ Each 25c; 3 for 65c; Doz. $\$ 2.50 ;$ per 100, $\$ 12.00$ Medium size bulbs, Doz. $\$ 1.50$; per $100, \$ 8.00$

Sonnenberg won first prize at the Iowa Gladiolus Society Show of 1926 for the best single spike of any variety selling for $\$ 10.00$ or more Exhibited by Merl E. Nellis. 


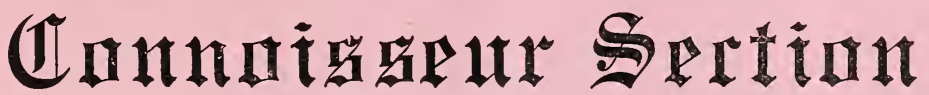

\section{BILL'S ORIGINATIONS}

As Good As the Best and Better Than Hany

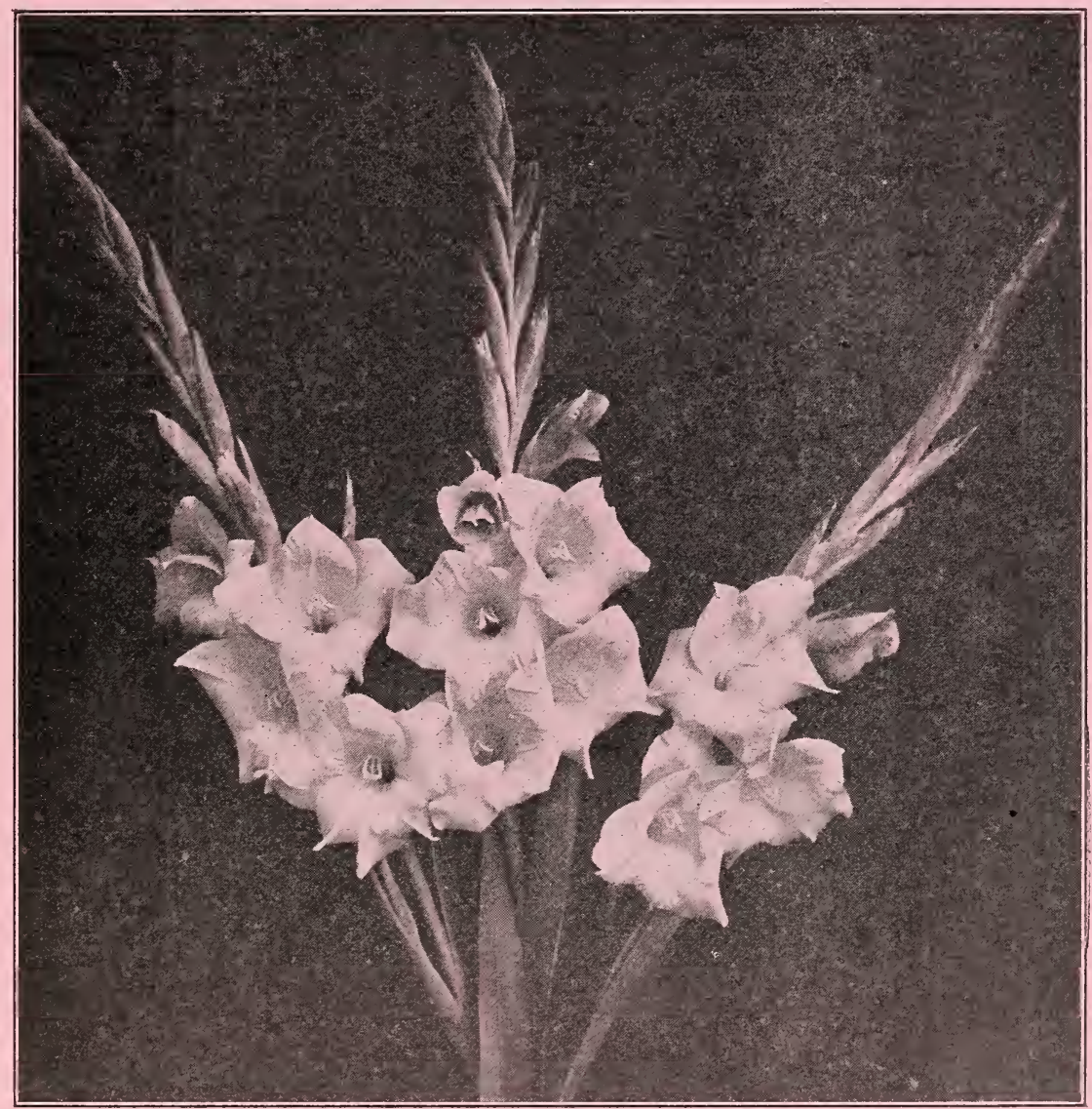

SUMMER DREAM

On these pink pages we are listing the newer rare varieties. These are the ones the Glad Fans are looking for. Each one has some outstanding character which makes it worthy of a place in the connoisseur's garden. All are "BILL'S ORIGINATIONS" of exceptional merit. Mr. Charles Gersdorff has classified and rated many of them. Just remember that when he rates a Glad 80 or better he considers it belongs in the highest class of Super Glads. These are the varietie's we used most extensively in our exhibits which won the four silver cups on page 4. The 1927 introductions are listed on page 32 . 
ALMA MATER - (Bill's Origination) So named because it embodies the colors of the originator's Alma Mater (The University of Tennessee). Beautiful large cream flowers with strong orange chrome throat. An unusual orange and white combination. Vigorous grower, large flowers and several open at once .....

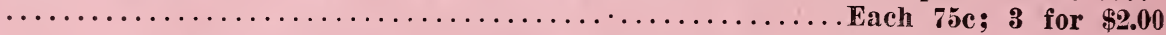

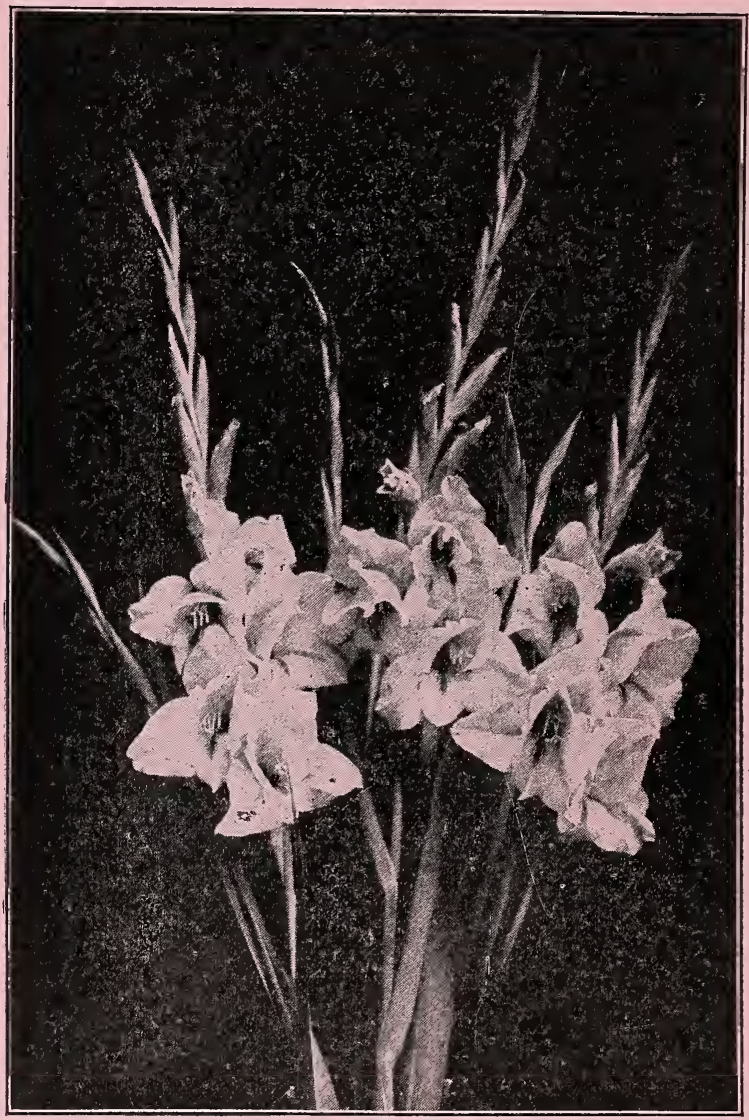

ALLEN V. BUNCE

ALLEN V. BUNCE-(Bill's Origination) Livid orange yellow with clear central lines of deep claret. Large well expanded winged flowers gracefully placed on wiry stalks. This variety was the sensation of the exhibit at the Rochester Exposition in 1922. Destined to become immensely popular as soon as there is stock available $\ldots \ldots \ldots \ldots \ldots \ldots \ldots \ldots \ldots \ldots \ldots \ldots \ldots$. Each $\$ 1.00 ; 3$ for $\$ 2.50 ;$ Doz. $\$ 10.00$

BEATRICE-(Bill's Origination) (Prim.) Something entirely new! Appearance and texture of soft crepe paper. Tall, graceful stalks with well opened slightly hooded and frilled blossoms. BEATRICE is eosine pink laid over cream ground. This color is veined over the cream in such a way that the surface has a

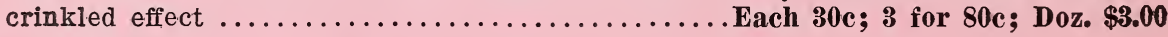

BETTY BUNCE-(Bill's Origination) Pale lilac flaked phlox purple. Creamy throat with delicate lines of true purple. Tall and straight with large flowers of excellent substance. Rated $95 \%$ by Gersdorff $\ldots . \ldots \ldots \ldots$. Each 75c; 3 for $\$ 2.00 ;$ Doz. $\$ 7.50$ 


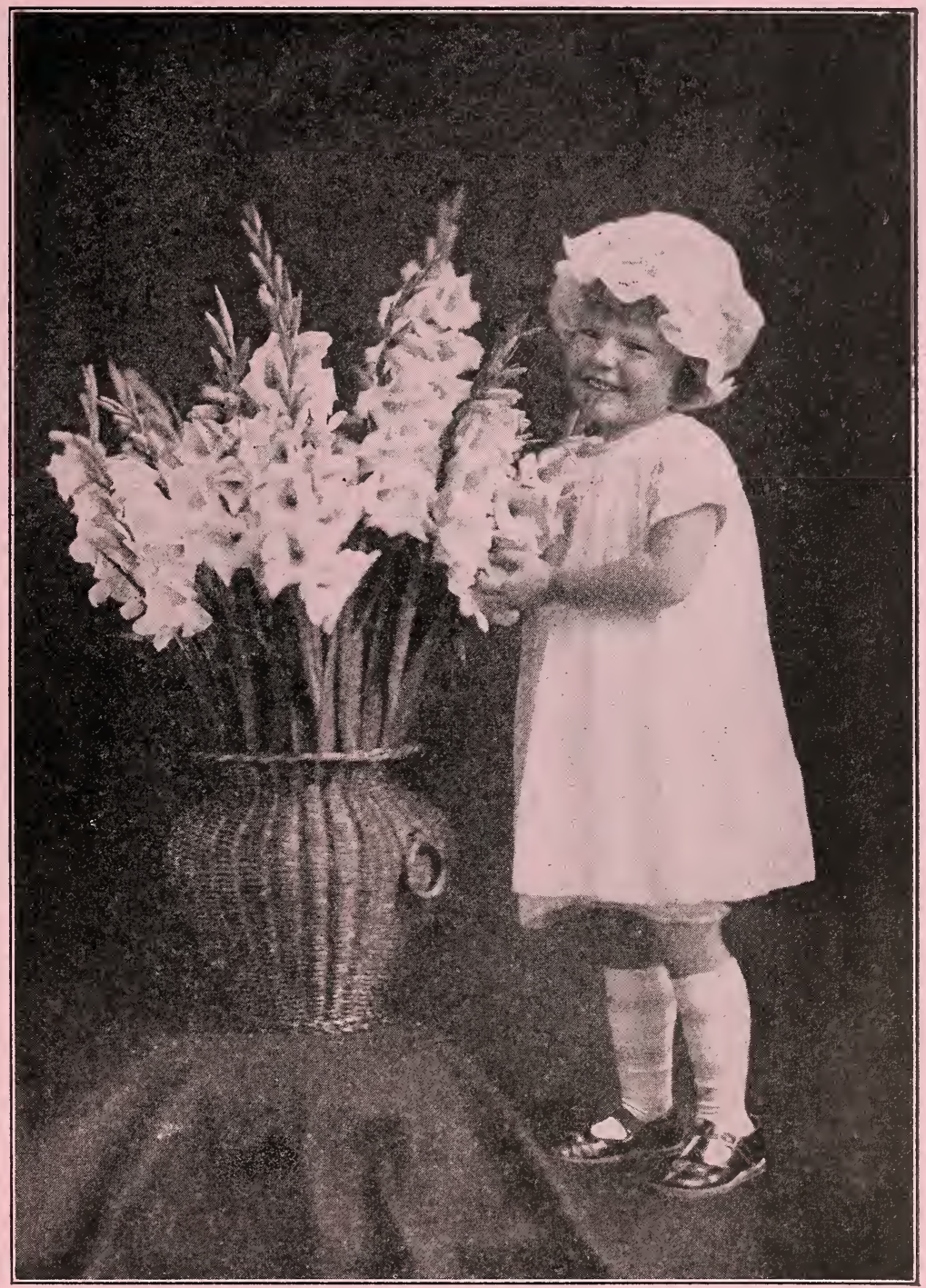

\section{BETTY JOJ}

BETTY JOY-(Bill's Origination) Named for the flower of our household, now five years old. Won honorable mention at Rochester A. G. S. Show as a commercial cut flower variety. Soft creamy white flushed LaFrance pink. Strong grower, long flower spikes with 6 to 10 perfect flowers opening at a time. Rated $97 \%$ as a commercial flower by Gersdorff $\ldots \ldots \ldots \ldots .$. Each $\$ 1.00 ; 3$ for $\$ 2.50 ;$ Doz. $\$ 10.90$ 


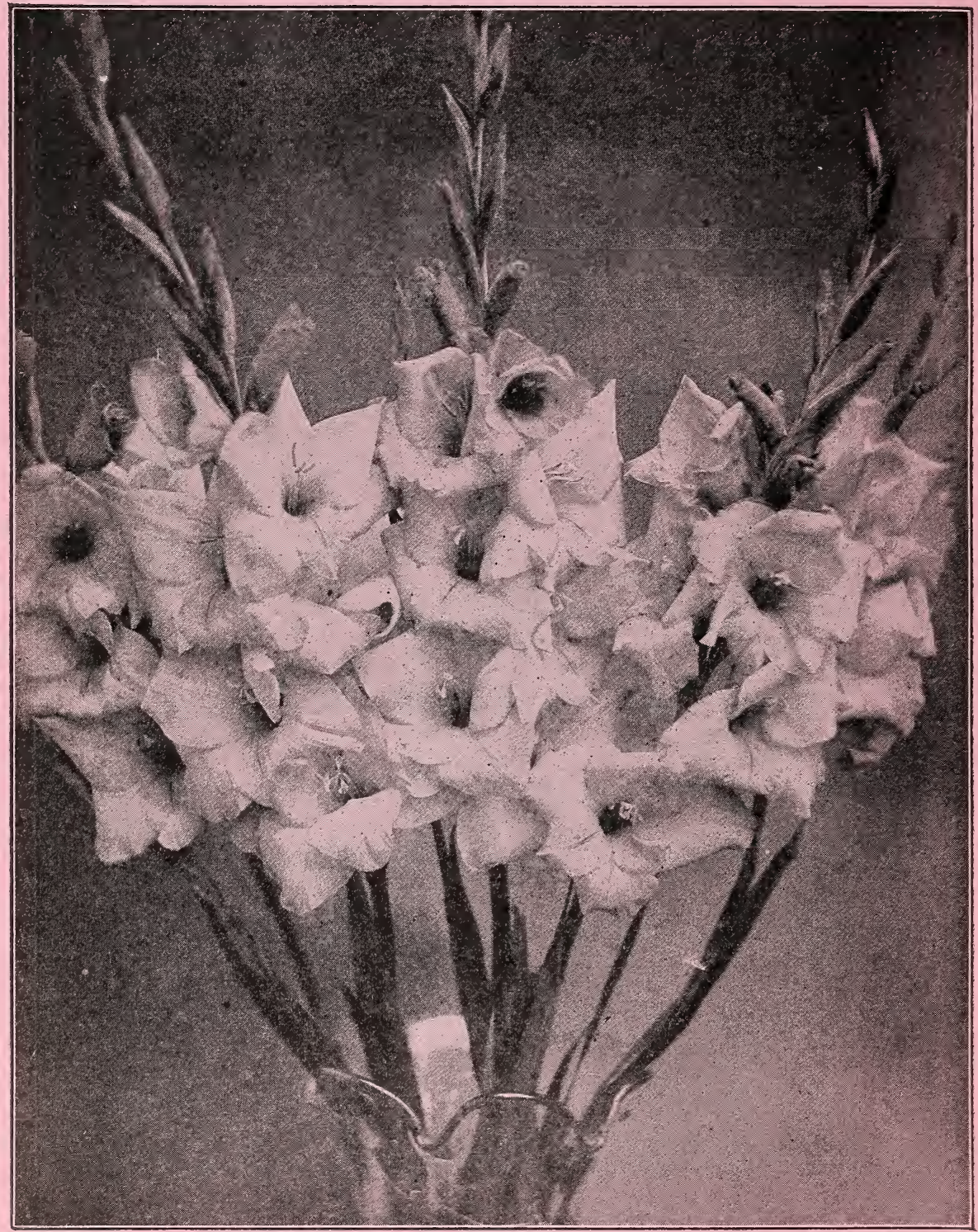

BREAK O' DAY

BREAK 0'DAY - (Bill's Origination) The above cut will give some idea of the size and beauty of this variety. It is really one of the very finest Glads we have ever seen. Massive spikes with several flowers opening at a time. Blooming extra early, it's soft LaFrance pink flowers will always be marketable at high prices. The pink is flushed over a cream ground and the shade is deeper at tips of petals. There is a zone of martius yellow on lower petals with delicate central lines of Brazil red. The most striking extra early variety ever produced ............... Large Bulbs $\ldots \ldots \ldots \ldots \ldots \ldots \ldots \ldots \ldots \ldots$. Each $\$ 4.00$; 3 for $\$ 10.00 ;$ Doz. $\$ 40.00$ Medium Size $\ldots \ldots \ldots \ldots \ldots \ldots \ldots \ldots \ldots \ldots \ldots$ Each $\${ }^{2} .00 ; 3$ for $\$ 7.50 ;$ Doz. $\$ 30.00$ Small Size ...................Each $\$ 2.00 ; 3$ for $\$ 5.00 ;$ Doz. $\$ 20.00$ Cormels $\ldots \ldots \ldots \ldots \ldots \ldots \ldots \ldots \ldots \ldots \ldots$ Each $25 \mathrm{c} ;$ Doz. $\$ 2.00$; per $100 \$ 15.00$ 


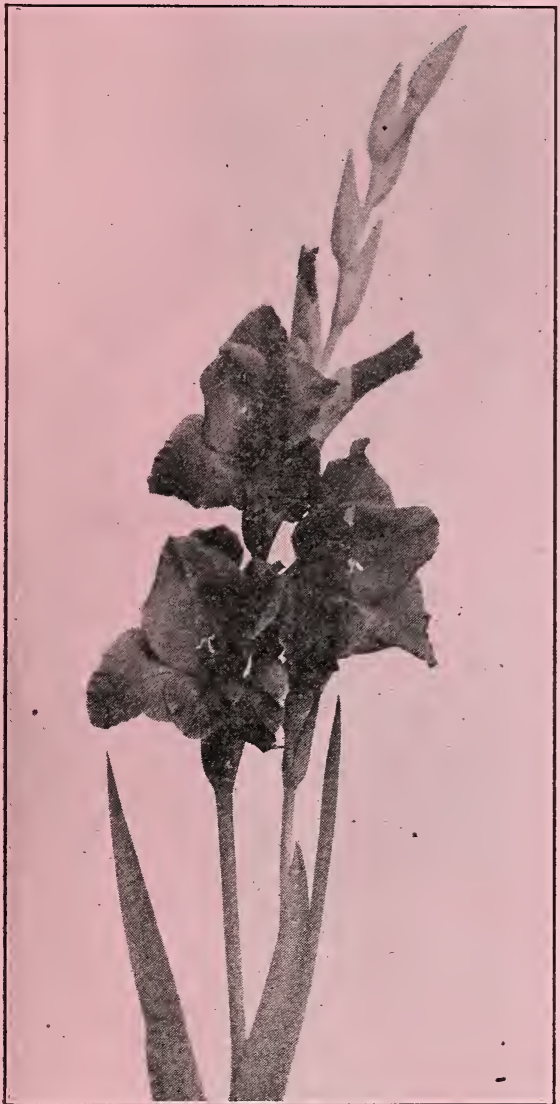

CHAMELEON

(Description Below)

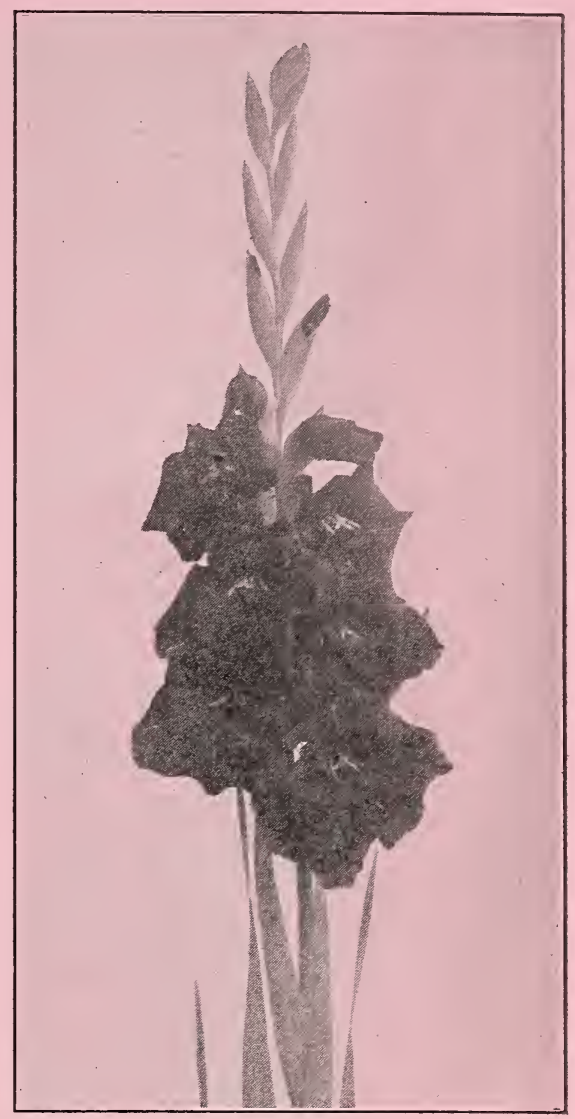

NOBILIS

(Description on Page 27)

CHAMELEON-(Bill's Origination) The little chameleon is noted for its changing color. This variety resembles the chameleon in that the color changes at each slight turn in the sunlight. Reminds one also of a delicate changeable silk with soft melting shades of lilac, purple, violet and orange which blend together perfectly. Slightly ruffled petals, good substance and excellent grower. An unusual exhibition variety. See illustration above ....... Each 40c; 3 for $\$ 1.00$; Doz. $\$ 4_{0} 00$

CANANDAIGCA RED-(Bill's Origination) Winner of 1st Prize for the best new seedling at the A. G. S. Show, 1921, at St. Thomas, Ont. A solid self color of red shade slightly lighter than true carmine. Among the thousands exhibited at St. Thomas, Ontario, there were none of this same shade. Strong grower, large massive spike;s, wond:rful indiviaual flowers. A stunning acquisition to the red class. Rated $97 \%$ by Gersdorff $\ldots \ldots \ldots \ldots$. Each $\$ 3.00$; 3 for $\$ 7.50$; Doz. $\$ 30.00$

"Lucette bloomed for all she was worth. She sure cuts loose when she starts. Sold most all spikes at wholesale at a time when the ash barrel was getting a big per cent of the cut. I think every one of those Lucette bulblets made about two bulbs. Friend wife favors Opalescent and I Therla because she is so early and Lucette because she blooms so strong and is so prolific." CLIFFORD L. JESSUP, Ind. 


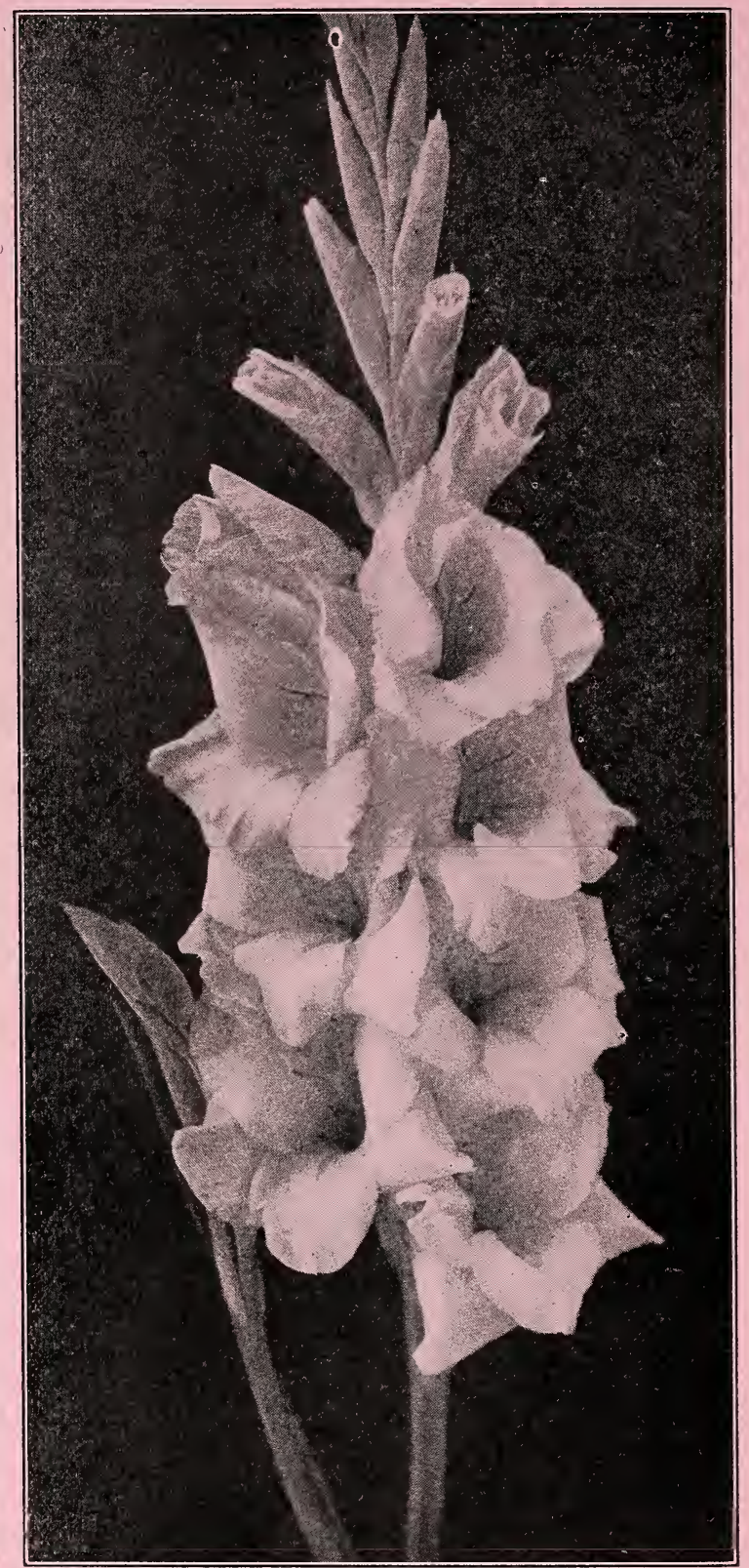

CLEOPATRA

CLEOPATRA-(Bill's Origination) (Ruffled) Very deep yellow. Large massive spikes. Heavy substance. Created a sensation at the Rochester Exposition. Rated $98 \%$ as an exhibition variety by Gersdorff. Late flowering ..............

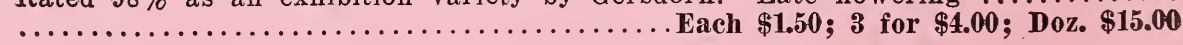




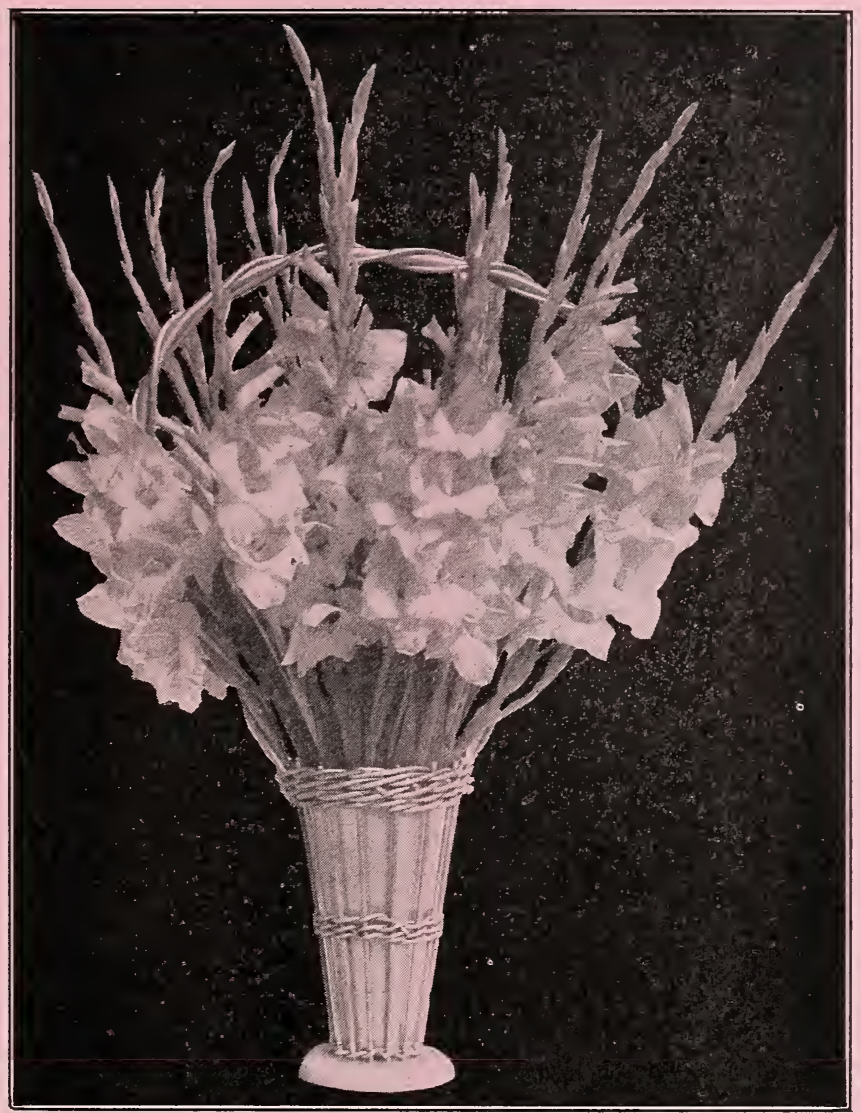

\section{DEBUTA NTE}

DEBUTANTE-(Bill's Origination) (New 1926) Extra large geranium pink, pure self color, with light throat feather of Tyrian rose. Flowers well placed in double rows, with 6 to 8 open at once. Excellent keeper, Each 75c; 3 for $\$ 2.00$; Doz. $\$ 7.50$

CREATORE-(Bill's Origination) The world famous musician and band leader, Guiseppe Creatore, chose this one as his ideal among Glads. With his permission we have named it CREATORE. With ordinary field cultivation the first flowers frequently measure 7" across. Robust, imposing and wonderfully thick substantial petals make it an extraordinary acquisition. Produces tall strong spikes with 16 to 18 buds about mid-season. It is a clear self color, Rose dore'e with a throat line of carmine red. One of the sensations at the A. G. S. Trial Grounds. Stock is very limited and we are offering only blooming size bulbs this season, 1 inch

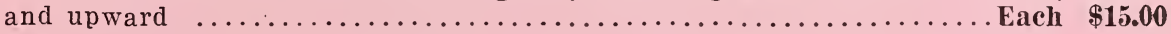

CROWN OF GOLD-(Bill's Originaticn) Pure straw yellow, tall, large flowers placed in a single row. Frequently 10 to 12 flowers open at once. One spike on exhibition at the A. G. S. Show in Rochester, 1925, made a hit with those who know Glads. Only flowering bulbs, 1 inch and up, for sale this season ..Each $\$ 5.00 ; 3$ for $\$ 12.50$

Don't overlook Opalescent on Page 38. You will miss something good if you do not include it in your selection. 


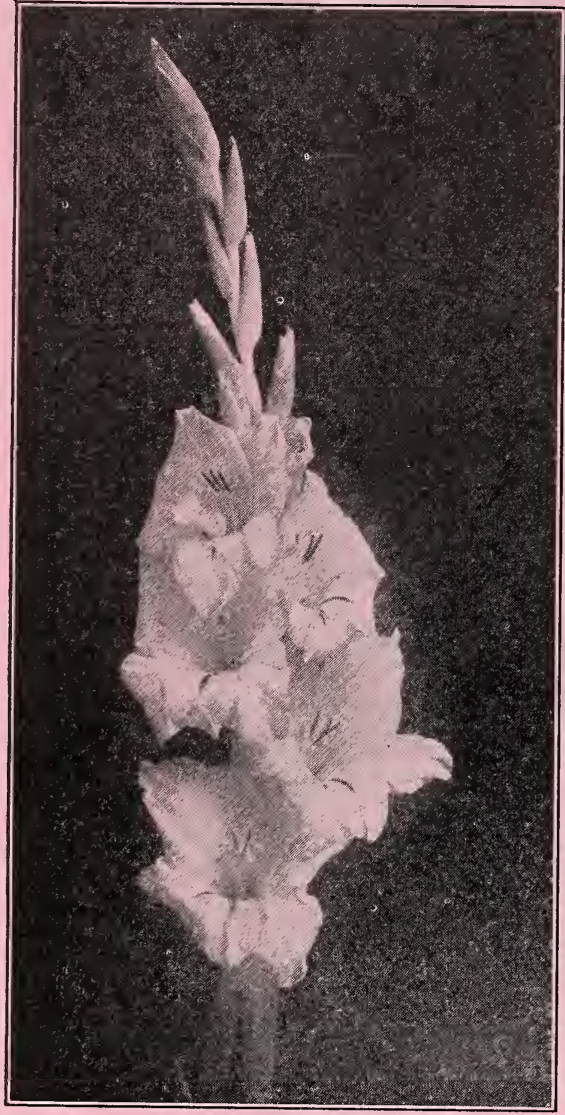

DU GA N NE DELIGHT (Description Below)

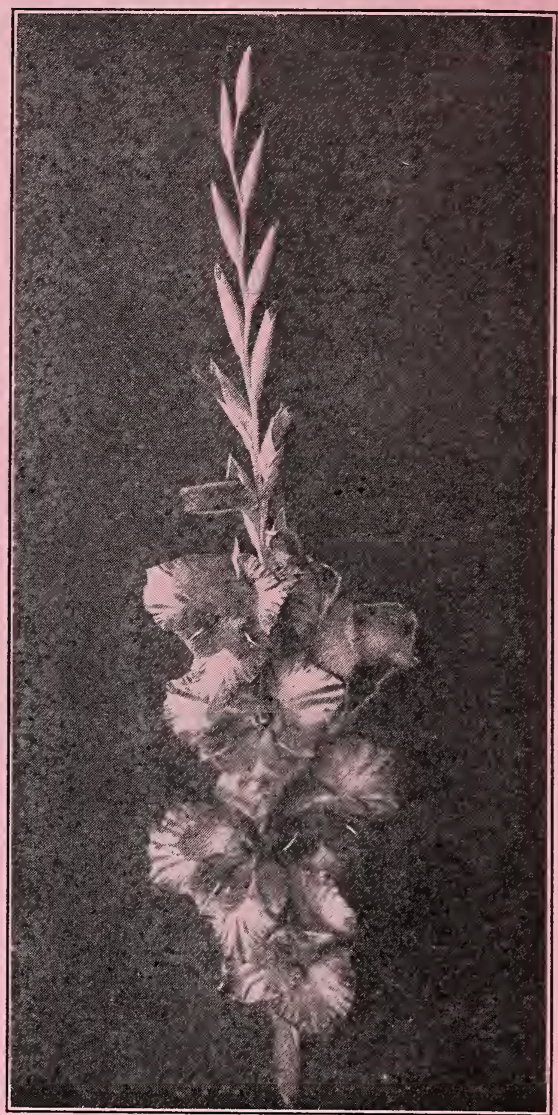

POPULA RITI

- (Description on Page 29)

DU GANNE DELIGHT-(Bill's Origination) (New 1926) Extra large ruffled variety. Cream flushed cameo pink shading to rose pink at edges of the petals. Strong central lines of Amaranth purpie. Sturdy strong plants with long flower heads and several massive b!noms open at a time. Thick petals and fine keeper ........ $\ldots \ldots \ldots \ldots \ldots \ldots \ldots \ldots \ldots \ldots \ldots \ldots \ldots \ldots \ldots$ Each $40 \mathrm{c}$; 3 for $\$ 1.00 ;$ Doz. $\$ 4.00$

DARDANELLA - (Bill's Origination) (NE' 1925) This is entirely different from anything else in our list. Flowers are Congo pink flaked deep hellebore red at the tips. Strong feather of jasper red on straw yellow throat. Tall and straight with $\delta$ to 10 open flowirs placed in double row. Best of the ashen varieties ......

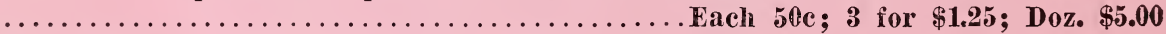

EARLY LADDIE--(Bill's Origination) One of the early ones. Soft geranium pink shaded to barium yellow in the throat. Central lines of carmine on the lower petals. Good size, wide open and Extra Early ......Each 30c; 3 for 80c; Doz. $\$ 3.00$

EARLY LASSIE-(Bill's Origination) (Prim.) Ivory white with a faint flush of lilac on upper petals. Lower petals primrose yellow, much smaller and reflexed with central lines. Strong grower and often branched. Very early. Rated 90.5 by Gersdorfi $\ldots \ldots \ldots \ldots \ldots \ldots \ldots \ldots \ldots \ldots \ldots \ldots \ldots$ Each $30 \mathrm{c} ; 3$ for $80 \mathrm{c} ;$ Doz. $\$ 3.00$ 
EVANGELINE-(Bill's Origination) Large, well expanded flowers of spinel pink with distinct carmine feather on straw yellow throat. A combination of new shades. Rated 85.7 by Gersdorff .............................. 50c ; 3 for $\$ 1.25 ;$ Doz. $\$ 5.00$

FASTIDIOUS-(Bill's Origination) Very large open flowers of delicate shell pink, shaded to ivory white at the throat. Very airy and graceful. One of the finest new glads. Attracted much atiention at the A. G. S. Exhibits in Rochester and New York city. A rather late bloomer. Rated $92 \%$ by Gersdorff ...............

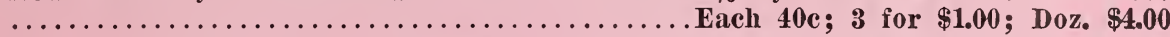

GALAXY - (Bill's Origination) (Ruffled) Large ruffled cream flowers flushed with pale lavender violet. The throat is Naples yellow with distinct feather of Amaranth purple. Extra strong, ruffled, well open and petals reflexed at the tips

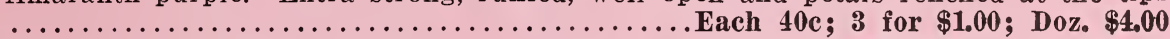

GOLDEN MAID-(Bill's Origination) (New 1925) Beautiful ruffled large Marguerite yellow shaded to primrose yellow in the throat. Usually 4 or 5 wide open flowers with distinct central line of Amaranth purple on lower petals. Extremely vigorous grower, broad toliage and strong flower spikes. Rated 88.8 by Gersdorff .......

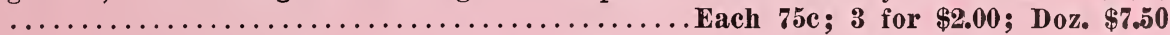

GYPSY BUTTERFLY - (Bill's Origination) (New 1925) Vivid deep spectrum red with large throat blotch and feather. The blotch resembles a beautiful large butterfly in the center of each flower. Well opened flowers, long spikes, slight frill and

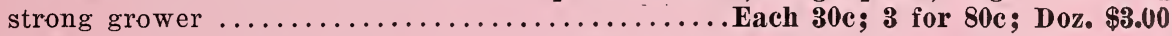

HALCYON-(Bill's Origination) A very strong grower, always straight, and throwing flower spikes with 18 to 24 buds. Unusual in the length of the flower head and it opens 6 to 8 large flowers at a time. Regular arrangement of flowers on the stem, spacing perfect. A beautiful soft rose pink, shading deeper toward the petal tips. Ideal exhibition and florist type. Rated 93 by Gersdorff $\ldots \ldots \ldots \ldots \ldots \ldots \ldots$

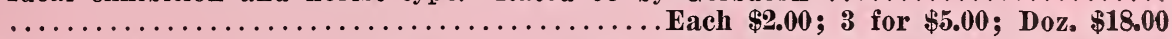

HARVEST MOON-(Bill's Origination) Marguerite yellow shaded deeper at the center, which carries a faint line of Chinese violet. Strong vigorous growth with 16 or more buds. Flowers placed in a double row, facing properly and of good size. Excellent substance, good keeper, opening 8 or more flowers at once. Rated 88.7 by Gersdorff $\ldots \ldots \ldots \ldots \ldots \ldots \ldots \ldots$ Each $75 \mathrm{c} ; 3$ for $\$ 2.00 ;$ Doz. $\$ 7.50$

HOPEWELL WHITE-(Bill's Origination) Another pure white, with vigorous, strong growth, well formed spike, good large flowers. We believe this will prove an excellent forcing white, as it never shows any flaking of color. Gersdorff has rated it at 90.6 as a commercial white, putting it in the class of Super Glads .........

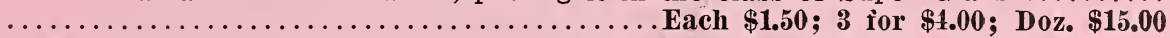

HUMDINGER-(Bill's Origination) Extra large heavy massive blooms of begonia rose flaked with scarlet. Beautiful throat markings of scarlet red. Flowers well expanded and 5 to 7 inches across. Heavy petals of great substance. Rated $92 \%$ by Gersdorff ............................ Each 75c; 3 for $\$ 2.00 ;$ Doz. $\$ 7.50$

KING MIDAS-(Bill's Origination) (Prim.) Not exactly the color vf the gold hoarded by King Midas, but a pure picric yellow with a very faint line of Garnet brown in the center. The largest we have ever seen of the primulinus form. Not a commercial variety, but an odd and attractive novelty for the fans. Rated 89 by Gersdorff $\ldots \ldots \ldots \ldots \ldots \ldots \ldots \ldots \ldots \ldots \ldots \ldots$. Each 75c: 3 for $\$ 2.00 ;$ Doz. $\$ 7.50$

LANCELOT and ELAINE-(Bill's Origination) In Tennyson's "Idylls of the King" two characte:s are portrayed. LANCELOT, the lordly knight, and ELAINE, the lily maid of Astalot. LANCELOT, a tall robust livid pink, stands forth to dispute all claims to garden chivalry; wonderfully strong and beautiful. ELAINE, the Fair and Lovable, a beautiful lily white with faint lilac at the throat. Both produce wonderfully strong full spikes of blooms and make a superb combination. ELAINE was awarded First Class Certificate by the American Gladiolus Society in 1924. See illustration on page 42 LANCEL0T, Each 75c; 3 for $\$ 2.00$; Doz. \$7.50 ELAINE, Each 50c; 3 for $\$ 1.25 ;$ Doz. $\$ 5.00$

Look up Lucette on Page 15. A Dozen or one hundred Lucette should be included tor a fine white variety. 


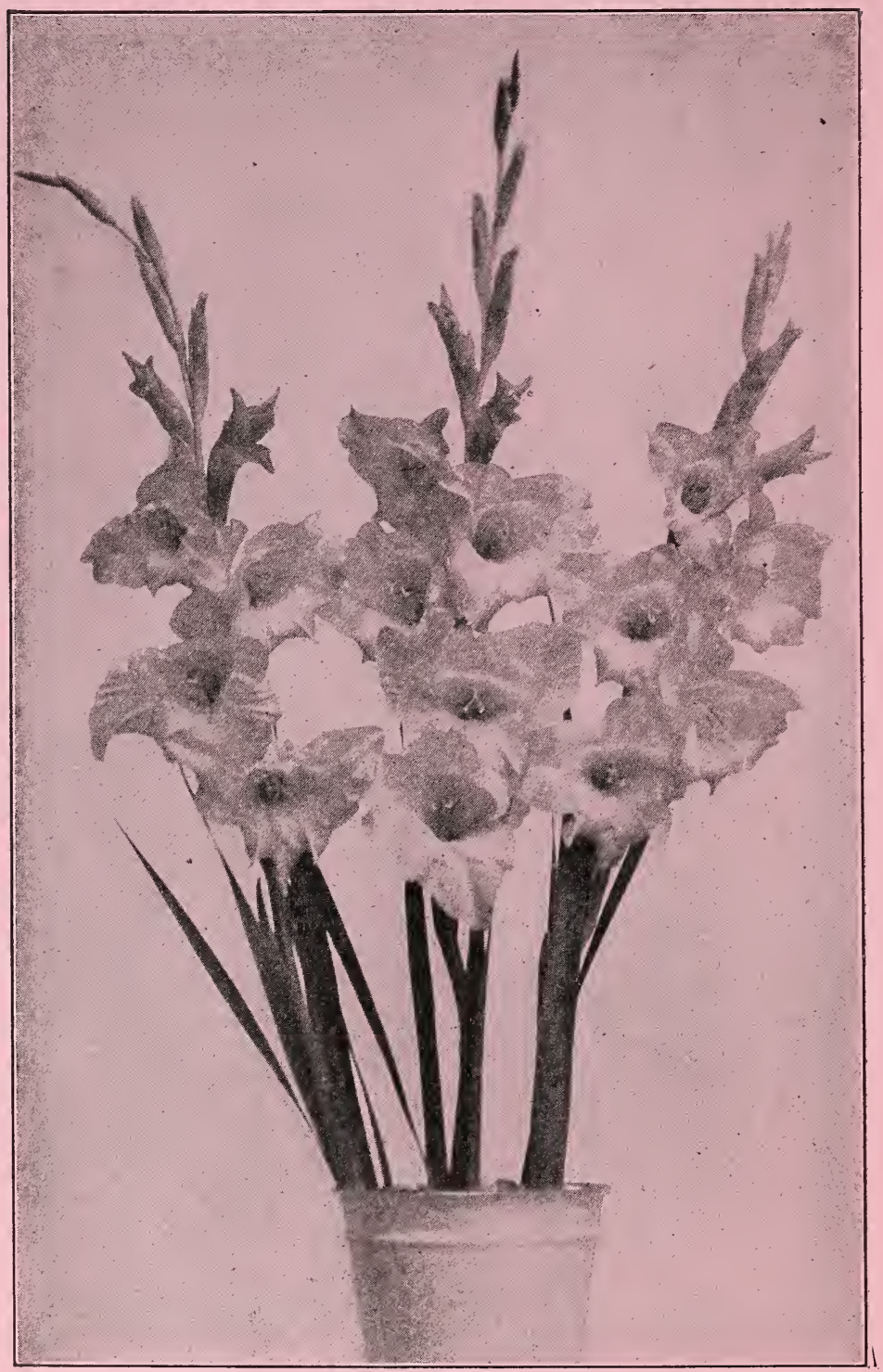

GLA DDIE BOY

GLADDIE BOY - (Bill's Origination) This variety was one of the outstanding new productions at the New England Gladiolus Society Exhibition at Boston in 1924. The Massachusetts Horticultural Society voted a Special Award of Merit. At the American Gladiolus Exhibit in New York city, GLADDIE BOY was again in evidence, winning the class of the "Most Beautiful Basket of Glads", as well as the class for the "Most Artistic Table Decoration". It is the Primulinus Grandiflorus type retaining the delicate characteristic coloring. Flowers are well expanded with only a slight hooded effect. Mature bulbs throw spikes with 18 to 20 buds, and opening 6 to 8 perfect flowers at a time. The color is very distinctive, the general effect being a Grenadine pink gradually blending with straw yellow deep in the center. The petals are most gracefully frilled ....Each $\$ \mathbf{1 . 0 0 ;} 3$ for $\$ 10.00$ 
LA ROSE-(Bill's Origination) (New 1925) A pure self color of deep Tyrian Rose with extremely velvety surface. Heavy petals, good foliage, excellent form, wide open flowers. A new variety that is sure to please the most exacting fancier. Gersdorff puts this in the Super Glad Class, rating it 90 for exhibition and 88.9 as a commercial variety. An unusually good keeper when cut ...Each $\$ 1.50$; 3 for $\$ 4.00$

MANDALAY - (Bill's Origination) (New 1926) An Oriental combination of colors. Rose doree flaked with Indian lake at the tips. Extremely vigorous tall spikes with 6 or more large flowers open at once ........ Each 35c; 3 for 90c; Doz. \$3.50

MARCELLA-(Bill's Origination) (New 1925) Soft rose with creamy throat and maroon penciling. Large flowers well placed and several open. Received favorable comment at the Boston Show, 1924. Rated $90 \%$ as a commercial variety by Gersdorff..$\ldots \ldots \ldots \ldots \ldots \ldots \ldots \ldots \ldots \ldots \ldots \ldots$ Each 30c; 3 for 80c; Doz. $\$ 3.00$

MATAD0R-(Bill's Origination) (New 1926) A tall strong husky grower that appealed strongly to our visitors the past summer. A deep Hermosa pink with rosy flush and distinct feather. Unopened buds have a soft flush of strawberry pink. Rather late bloomer. Petals waved and stem usually gracefully curved. Gersdorff

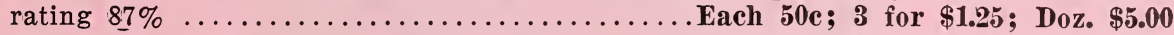

MYRON-(Bill's Origination) Named after a young Ohio farmer who is a go-getter. He always admired our red ones. This is a rich velvet spectrum red, shaded to Begonia rose at tips of petals. Large open blooms. Well placed, on strong stalk

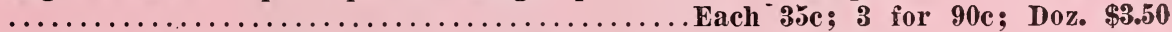

NACO0MEE-(Bill's Origination) The name given this variety is an Indian name meaning "Handful of Flowers". One spike is surely a handful or even a whole bouquet. The general tone is lavender with various shades and tints. Rated by Gersdorff 82.7 Exhibition $\ldots . . \ldots \ldots \ldots \ldots \ldots \ldots \ldots$ Each $50 \mathrm{c} ; 3$ for $\$ 1.25 ;$ Doz. $\$ 5.00$

NIGHT BIRD-(Bill's Origination) (New 1926) Winner of 1st prize A. G. S. Show in 19.25 for best maroon variety. Extra large, very dark, with soft velvet surface. Heavy petals and a good keeper ............. Each 50c; 3 for $\$ 1.25 ;$ Doz. $\$ 5.00$

1925 ROSE-(Bill's Origination) (New 1926) Rose red flaking over deep rose pink. Attractive creamy white dash on lower petals. A deeper shade and more attractive than 1910 Rose. Massive flower heads with $\&$ to 5 large round blooms open at once. Gersłorff rates it 89.8 Exhibition ...... . Each $40 \mathrm{c} ; 3$ for $\$ 1.00 ;$ Doz. $\$ 4.00$

NOBILIS-(Bill's Origination) One of those velvet deep reds. It does not fade in wet weather, as most others of this type do. Ridgeway's Color Chart calls it Amaranth purple. Many massive frilled flowers open at a time. See illustration on page

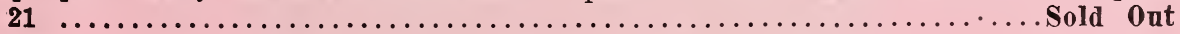

NORWALK-(Bill's Origination) Named after the charming little City of Norwalk, Ohio, where it first came into bloom. Large open flowers well placed on a strong straight stem. Deep scarlet with large yellow throat. Petals are pointed, slightly waved and a faint tinge of blue on the borders. Extremely vigorous with many large flowers open at a time. Rated $97 \%$ by Gersdorff as a commercial variety

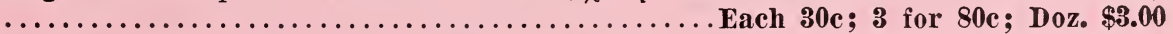

OH BOY : - (Bill's Origination) When you see this variety you will fully realize the significance of the name. Your exclamation of delight will prolong the "Oh!" and follow with a sharp explosive "Boy". A brilliant red, self color without markings. Flowers 7" or more across and petals extremely thick. Sometimes with 4 or 5 of these mammoth flowers at a time it gives the impression that the limit has been reached. Even with this mass of flowers the stalk is strong enough to hold it erect. Flowers are wide open and the petals are broad rather than narrow and pointed. Only blooming size, $1^{\prime \prime}$ and up, for sale this year ...........Each $\$ 15.00$

OLYMPIAD-(Bill's Origination) (New 1925) The most vivid orange scarlet yet produced. The flowers appear to be literally on fire. Very large blooms sometimes measuring $5^{\prime \prime}$ across. Irregular arrangement of petals give it a distinctiveness all its own ........................ Each 50c; 3 for $\$ 1.25 ;$ Doz. $\$ 5.00$

"I have no favorite which I regard more highly than Break O'Day and I want as many as my moderate space will permit." FRANK I. JONES, Oregon. 


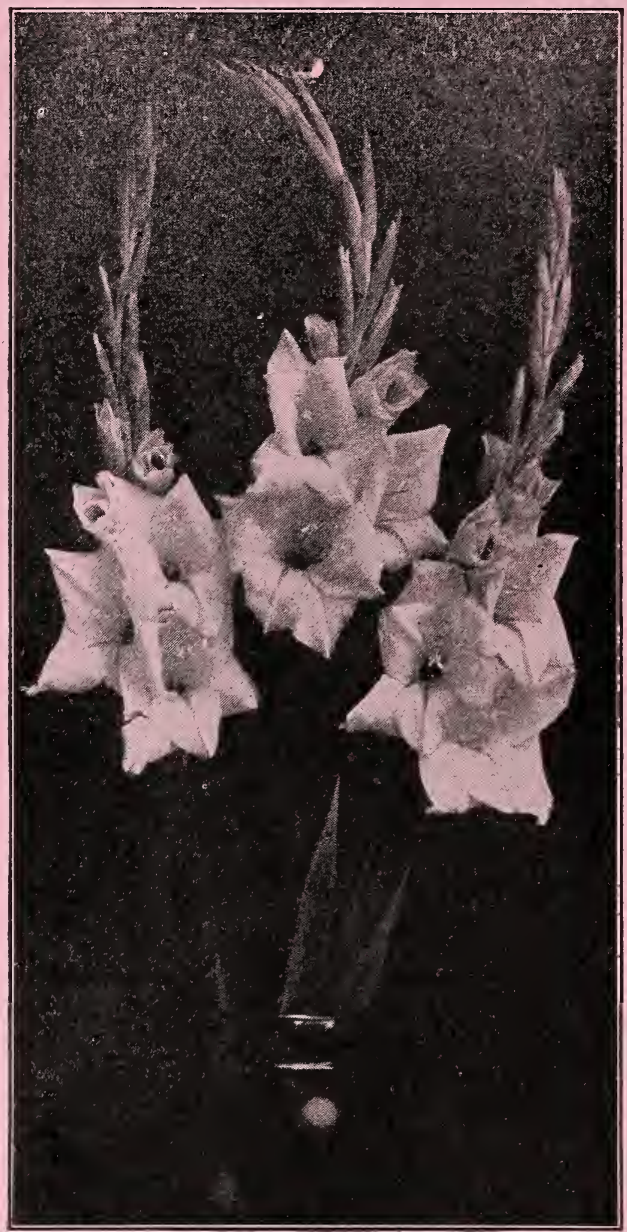

OPALESCENT

OPALESCENT-(Bill's Origination) Wonderful spikes of very large pale rose lavender. A pure self color with soft lilac throat lines. A vigorous grower with excellent foliage and strong straight bloom stalks. Flowers well placed with broad petals of good substance. As sparkling and pure as the water of the Adirondack Mountain stream for which it was named. One of the best in our list for cutting and shipping. Gives excellent results as a variety for greenhouse forcing. Rated $97 \%$ as a commercial flower by Gersdorff. OPALESCENT received Special Award of Merit by the American Gladiolus Society in $1924 \ldots \ldots \ldots \ldots$. . .

Each 35c; 3 for 90c; Doz. $\$ 3.50$

PATRICIA-(Bill's Origination) (New 1925) LaFrance pink shaded to hermosa pink at tips. Strong Tyrian rose feather on creamy throat. Tall with 18 buds and 6 $o p \in n$ at once. Fine for florist. See illustration on page 8 . Rates 88.4 commercial . .............................Each 40c; 3 for $\$ 1.00 ;$ Doz. $\$ 4.00$

PINK PRIDE--(Bill's Origination) (New 1925) This produces a very large loose flower head with 6 to 8 massive flowers open at once Good vigorous grower. Rosolane pink, flushed and flaked with Tyrian pink. An Extra Fine New Glad. Rates 91.1 Exhibition ............................. 75c: 3 for $\$ 2.00$; Doz. $\$ 7.50$ 
POPULARITY-(Bill's Origination) (New 1925) Very strong, vigorous grower of flame pink heavily flaked and striped bright red. The two inferior petals rich velvet red with light central dashes. Large size, several open at once and popular with our visitors. See illustration on page 24 ..Each $30 \mathrm{c} ; 3$ for $80 \mathrm{c} ; \mathrm{Doz} . \$ 3.00$

PRDI PICOTEE-(Bill's Origination) A very unusual primulinus hybrid with picotee edge of yellow bordering all petals. Center of petals is brilliant red. A distinct

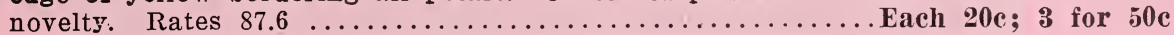

PRIORITY-(Bill's Origination) T'all, straight and strong. Large open flowers. Color is Venetian pink, shaded darker toward the tips. Faint central lines and feather of deep rose pink. Wonderful large, airy delicate variety of almost self color. Rated $98 \%$ by Gersdorff, both as an exhibition and a commercial flower. A sure Winner. Has given excelient results for greenhouse forcing .............

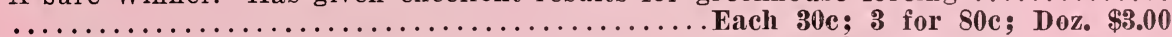

PROMETHEUS-(Bill's Origination) (New 1925) As Prometheus brought fire for the Greeks, so this new Glad brings fire to your garden. Most brilliant scarlet laid over peach red. Heavy feather of carmine in bold relief against a white zone. Very strong growth with 20 or more buds and 6 to 8 large flowers open at once. Exhibition rating $91.9 \ldots \ldots \ldots \ldots \ldots \ldots \ldots$ Each 30c; 3 for 80c; Doz. \$3.00

QUAKER MAID-(Bill's Origination) Soft lavender pink with delicate feathery throat markings. Tall and strong with many flowers open at a time. Fine for florist cut-flower trade. Late flowering. Rated $85 \%$ by Gersdorff ..............

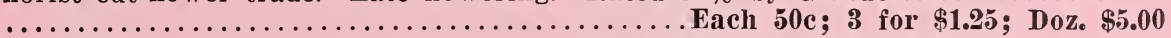

RED JACKET-(Bill's Origination) Large flaming scarlet flowers, borne on tall straight stalks. An excellent keeper with slightly ruffled petals. Named for the celebrated Chief of the Seneca Indians who founded the village of Canandaigua where this warrior flower was produced .......Each 50c; 3 for $\$ 1.25 ;$ Doz. $\$ 5.00$

ROBINHOOD-(Bill's Origination) Immense massive blooms of LaFrance pink tipped and flaked with scarlet. Strong feather of Amaranth purple in the throat. Extra strong and vigorous grower. Slightly frilled petals. Early bloomer. Rated $94 \%$ by Gersdorff ............................Each 75c; 3 for $\$ 2.00 ;$ Doz. $\$ 7.50$

ROBUSTO-(Bill's Origination) Soft peach red flaked with scarlet and velvet scarlet lines in the throat. Have measured spikes 28 inches from first flower to tip of buds with 24 buds on the main stalk and others on the side branches. Rated $93 \%$ by Gersdorff $\ldots \ldots \ldots \ldots \ldots \ldots \ldots \ldots \ldots \ldots . . \ldots a c h$ 40 $; 3$ for $\$ 1.00 ;$ Doz. $\$ 1.00$

“ROTARY" PINK-(Bill's Origination) Bright eosine pink, throat feathered rose doree, with dainty white medial dash. Opens 4 to 6 large well expanded blooms at a time. One of the very best for cutting. Will keep a long time. Rated 86.1 as commercial variety by Gersdorff $\ldots \ldots \ldots .$. Each $\$ 1.00 ; 3$ for $\$ 2.50 ;$ Doz. $\$ 10.00$

"ROTARY" WHITE-(Bill's Origination) (New 1926) Pure white. tall, strong grower. Several open at once, slightly frilled. Buds pale greenish tint. Good substance and usually branched ............................. 50c; $\mathbf{3}$ for $\$ 1.25 ;$ Doz. $\$ 5.00$

SERRATA-(Bill's Origination) This is entirely new type with the petals serrated or lacinated on the edges. This type first appeared among my seedlings in 1919. The flowers are of good size and a clear cream color. Besides its unique beauty it. is valuable to the breeder for producing others of this type. Strong healthy grower, good seed producer and multiplies well ......... Each $\$ 3.00$ : 3 for $\$ 7.50$

SONATA-(Bill's Origination) (New 1925) A robust white slightly flushed very light Phlox pink, strong throat lines of Aster purple. Usually 6 to 8 well opened flowers of good substance. Long flower head and excellent for florist trade.

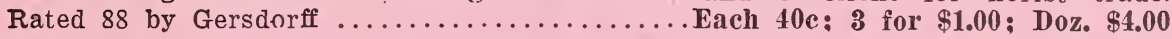

SONNENBERG-(Bill's Origination) Named in honor of the wonderful Sonnenberg Estate located in Canandaigua. Massive spikes of creamy pink, lightly flaked with lavender pink. The pink shade melts away to a soft yellow at the throat. Magnificent for exhibition or cut flower purposes. Stock limited. Not more than three to a customer ................................. $\$ 5.00$; 3 for $\$ 12.50$

Starlight took first prize. Class 56. Connecticut State Fair, 1926. Exhibited by George L. Hunt. 


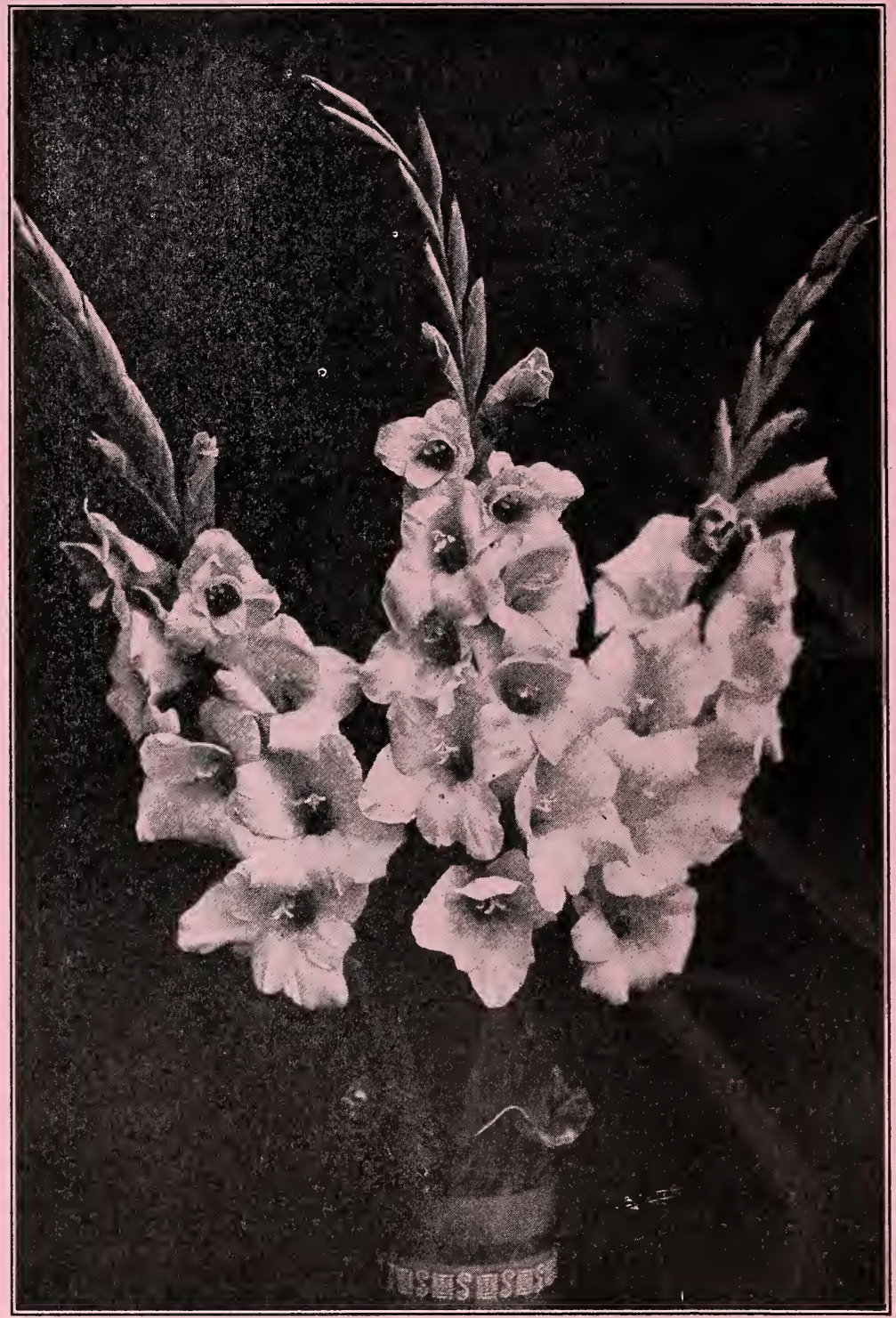

PICCA DILLY

PICCADILLY-(Bill's Origination) Pure creamy yellow, with amber throat. Wonderful strong spikes with many large flowers open at a time. This is one of the finest we have to offer. Rated $98 \%$ as a commercial variety by Gersdorff ......

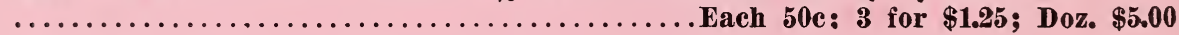

"I had great success with the Glads, I received from you last pring and you may expect another order in the spring of 1927. So mail me a copy of your 1927 catalog." L. L. ARNOLD, Ohio. 
STARLIGHT-(Bill's Origination) Early, extra strong Primulinus hybrid. Wonderful strong spikes of ruffled cream flowers with radiant lines of pomegranate on wax yellow throat. Extra prolific. often giving three and four stalks from one bulb. STARLIGHT received a Special Award of Merit by the A. G. S. in 1924 . See illustration on page 33. Rated 91.8 by Gersdorff, Each 30c; 3 for 80c; Doz. $\$ 3.00$

SUMMER DREAM-(Bill's Origination) Our records of the exact color have been mislaid. but it is one of those soft glistening pink varieties which everyone admires. The illustration on page 17 shows the form of the florets and the arrangement on the stem. Rated $89.7 \ldots \ldots \ldots \ldots \ldots \ldots \ldots \ldots$ Each $\$ 2.00 ; 3$ for $\$ 5.00$

SYLVAN QUEEN-(Bill's Origination) (New 1926) An early strong growing soft Begonia rose with carmine lines on lower petals. Neat form, good size and excellent substance. You would like it .......... Each 35c; 3 for 90c; Doz. $\$ 3.50$

TAJ MAHAL-(Bill's Origination) (New 1925) One of the most beautiful buildings in India was erected as a memorial to the Princess Taj Mahal. The style of its architecture is unique and it is constructed entirely of white marble inlaid with mother-of-pearl. A missionary returned from India suggested that we name this new production TAJ MAHAL (Pearl of the World), as its white with the flush of mother-of-pearl was suggestive of the memorial to the Princess. Round Blossoms, well opened and early $\ldots \ldots \ldots \ldots \ldots \ldots$ Each $\$ 1.00$; 3 for $\$ 2.50 ;$ Doz. $\$ 10.00$

THE ARISTOCRAT-(Bili's Origination) This is a true Aristocrat among the hundreds of new ones. Large strong massive spikes of most delicate coloring. A pale saffron pink flaked deep orange with cream throat and a very distinct violet feather. Slightly ruffled and extra large. Several flowers open at a time. Chas. Gersdorff scored this under the revised A. G. S. system and gave it $95 \%$ as an exhibition variety. Under his old system it scored several points higher ........

TRIUMPHO - (Bill's Origination) (New 1925) Light Marguerite yellow shaded to primrose yellow in the center. Hooded and winged, neat ruffle, 8 flowers opening at once. Strong straight spikes ............. Eäch 75c; 3 for $\$ 2.00 ;$ Doz. $\$ 7.50$

VICTOR-(Bill's Origination) (Ruffled) One of the largest ruffled varieties. A beautiful cream yellow with heavy ruby central lines. Tall, vigorous and extra fine. Exhibition variety. See illustration on page 33 . Rated 89.7 by Gersdorff

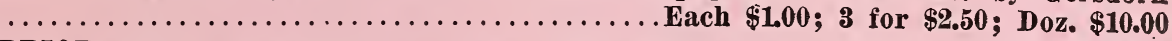

WARRIOR-(Bill's Origination) Deep velvet maroon with yellow medial dashes. Robust and strong with large well expanded blooms. Planted in May, it does not bloom until late September. Unequalled for an extra late dark red. Should be planted very early. Rated $97 \%$ by Gersdorff .... Each 75c; 3 for $\$ 2.00 ;$ Doz. \$7.50

WHITE ORCHID-(Bill's Origination) It will be difficúlt for us to convey to you the extreme grace, beauty and style of this variety without an illustration. The color is a pure cream white. The wing petals stand well open, measuring 4 to 5 inches across. The upper central petal gracefully curved forward. The three lower petals are somewhat smaller. All petals most beautifully frilled and of heavy substance which hold up well under adverse conditions. The type of the flower immediately gives the impression of an orchid by its extreme grace and poise. It is a strong grower and blooms rather early. Ours were nearly all gone before the Rochester show in August. Only blooming size, 1 inch and up, to offer

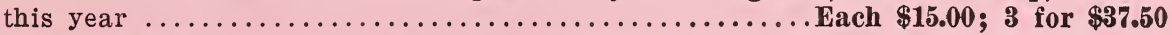

WHITE PREMIER-(Bill's Origination) The finest of the new white varieties we are offering. Pure white without markings or flakings. Strong constitution, massive heavy flower heads. We have not seen a pure white to equal this one. Gersdorff rates it 91.3 commercial value ................ Each $\$ 5.00 ; 3$ for $\$ 12.50$

\section{HOW TO PRONOUNCE GLADIOLUS.}

At the annual convention of the American Gladiolus Society in 1925 a resolution was adopted putting the society on record as approving the pronunciation Gla-di-o-lus. The accent on the third syllable with o as in note. The resolution also provided for the adoption of Gladiolus for both the plural and singular forms. The action taken has recelved the approval of nearly all fans and growers except the few who do not know the "war is over". 


\section{SEVEN NEW HIGH-CLASS INTRODUCTIONS FOR 1927}

ARABY-(Bill's Origination) (New 1927) The open flowers are flushed Rosalane pink with a very distinct, strong throat of Tyrian rose. The buds are clear Chatanay pink. A vase of these flowers with buds one color and open flowers another color forms an unusual and striking floral arrangement. The flowers are large, well

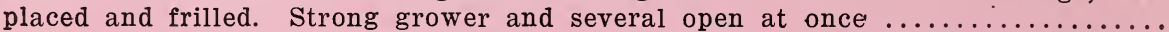

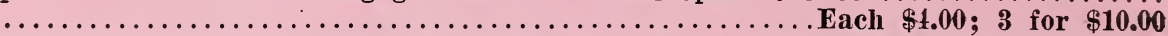

BROADELBIN-(Bill's Origination) (New 1927) (Ruffled) Massive close set flower heads of creamy white with throat marking of Rosalane purple. Several broad

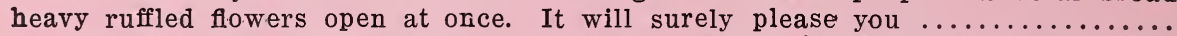

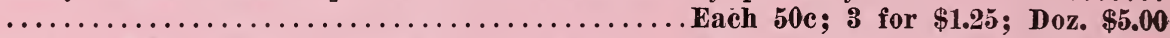

BOUNCING BET-(Bill's Origination) (New 1927) This is another white which we predict will be popular. It is a glistening white with a trace of cream toward the center and a soft plume of Persian lilac in the throat. Very straight and tall with 18 to 22 buds, and usually 6 to 8 perfect flowers open at a time. Petal edges slightly reflexed. Spacing and arrangement perfect for commercial type .....

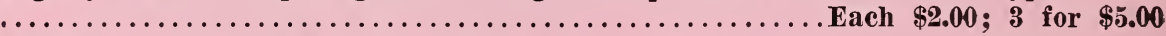

CHIEFTAIN-(Bill's Origination) (New 1927) A large flowered, pure Tyrian rose. Rather short growth but makes a fine display ..Each $40 \mathrm{c}$; 3 for $\$ 1.00 ;$ Doz. $\$ 4.00$

ECH0-(Bill's Origination) (New 1927) A new large flowered variety belonging to the lavender class with throat markings. It is Phlox pink, shaded deeper at the petal tips. Barium yellow zone in the center with plume of Phlox purple. Glistening surface ...............................Each 50c; 3 for $\$ 1.25$; Doz. \$5.00

FORT SUMTER-(Bill's Origination) (New 1927) Another red of exceptional merit. A pure self scarlet red. Very large wide open massive flowers with all petals nearly equal in size. Spikes often have 6 to 8 of these huge blooms open at once. Extra fine and stock limited. Not over 3 to a customer .. Each $\$ \mathbf{1 0 . 0 0 ;} 3$ for $\$ 25.00$

FLEETWO0D-(Bill's Origination) (New 1927) A soft melting light Geranium pink with 5 to 8 flowers open at once. Almost pure self color, on nice straight spike. Arrangement and size ideal for commercial use. Extra good keeper after cutting. You want it! Not over 3 to a customer ............... Each $\$ 5.00$; 3 for $\$ 12.50$

SPECIAL OFFER NO. 21

One Each of the Seven New Varieties on Page 32 for $\$ 18.00$.

SPECIAL OFFER NO. 22

Catalog Value, $\$ 129.70$.

One bulb of each, of the 73 varieties (Bill's Origination) offered on the pink pages for $\$ 100.00$.

Ready to go on the Press-and the printer tells me this space will be vacant!

Two minutes later-Bill MacFarlane, president of our Rotary club, hands me the following:

Glad Bill:

May Merry Christmas, Bill, Old Glad, Rain blessings on your head,

And may your New Year be as bright As "Canandaigua Red".

You've made your corner of the earth A beauty and a joy.

Step in and make the next twelve months Your best ones since a boy.

BILL MAC FARLANE, 


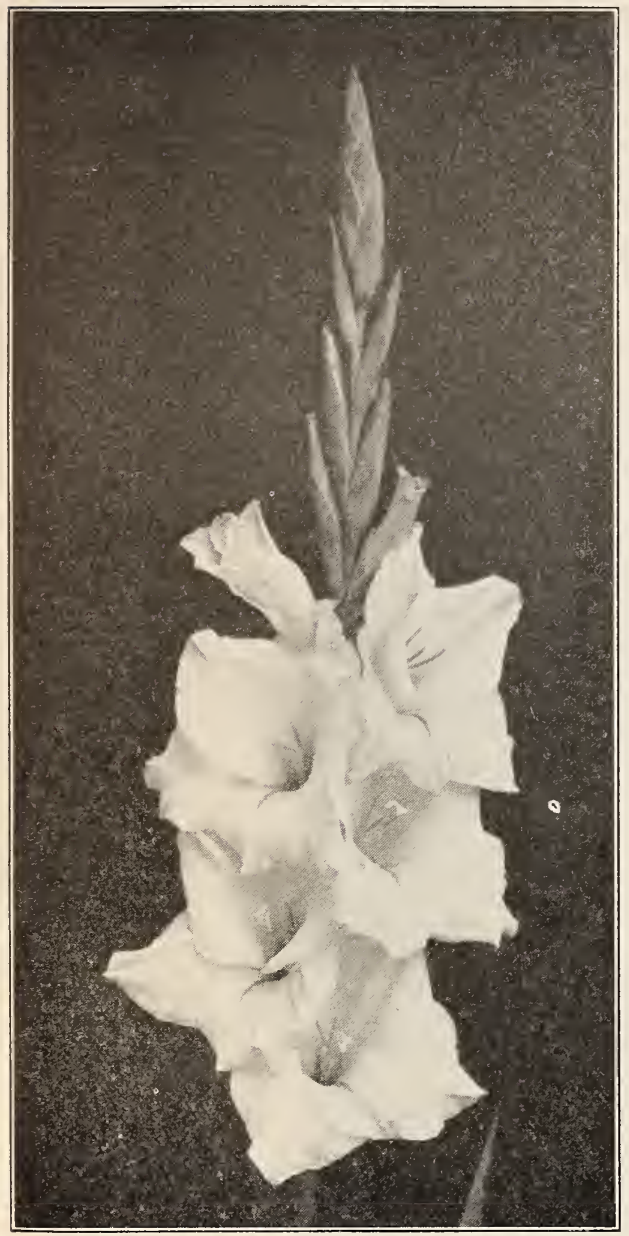

VICTOR

Description on Page 31

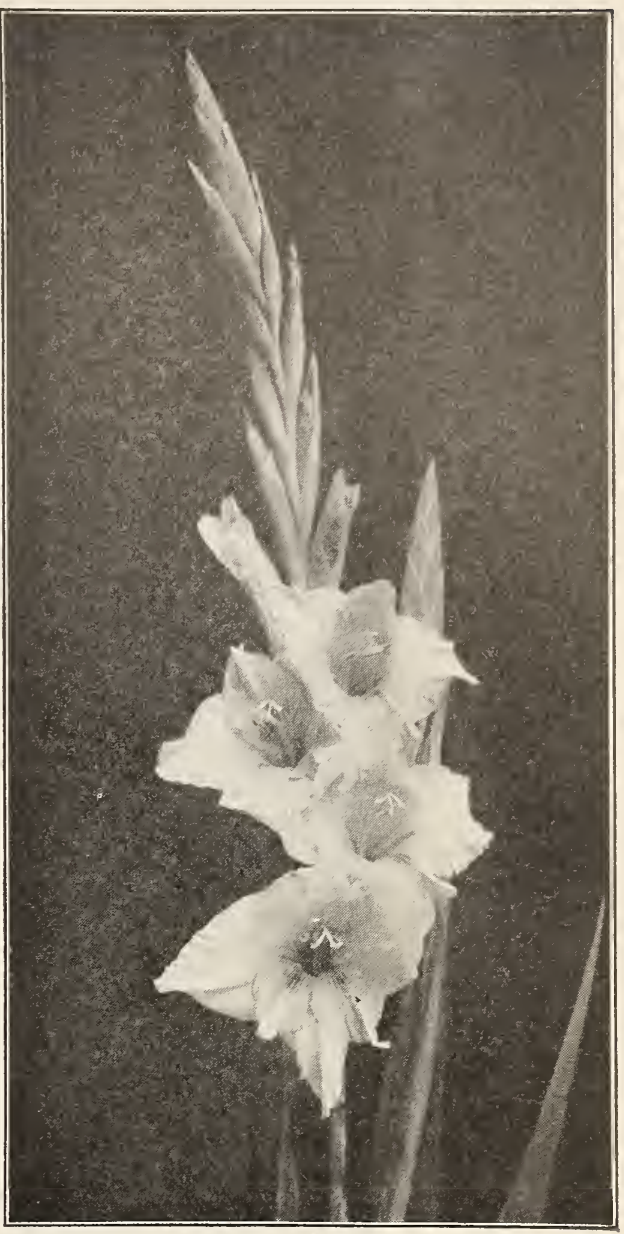

STA RLIGHT

Description on Page 31

P00 BAH-(Bill's Origination) (New 1927) When naming this I had in mind that character in the Mikado. Sort of a clown in some ways but really a very beautiful flower. Vivid Orange red with flecks on the petals. Opens 6 nice blooms at a time ..........................Each 25c; 3 for 65c; Doz. \$2.50

POPLLARITY-(Bill's Origination) See Page 29.

PRIDE OF LAYCASTER-(Kunderd) (Ruffled) Brilliant Orange salmon with deepe:

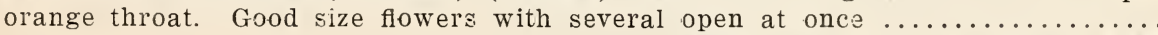

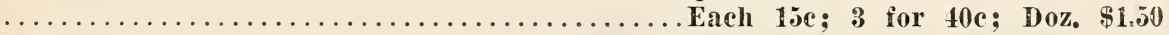

PRIM PICOTEE-(Bill's Origination) See Page 29.

PRIMULIXUS SPECIES-(Prim.) Native of South Africa. Small flowers of rich deəp pure yellow. Very useful in landscape plantings ..Each 10c; 3 for 25c; Doz, \$103

PRIMLNELLA-(Kunderd) (Prim.) Large ruffled beautiful orchid like flowe:s of

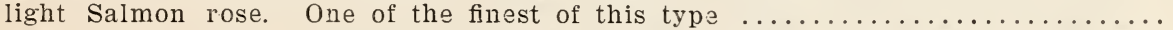
$\ldots \ldots \ldots \ldots \ldots \ldots \ldots \ldots \ldots \ldots \ldots \ldots \ldots$ Each 10c; 3 for 25c; Doz. $\$ 1.00$; per 100, $\$ 5.00$ PRIORITY-(Bill's Origination) See Page 29. 
PRONETHECS-(Bill's Origination) See Page 29.

PROPHET-(Bill's Origination) Large graceful open blooms of pure Geranium pink with feather and strong lines of Nopal red in throat. Vigorous grower ......... $\ldots \ldots \ldots \ldots \ldots \ldots \ldots \ldots \ldots \ldots \ldots$ Each $20 \mathrm{c}$; 3 for $50 \mathrm{c}$; Doz. $\$ 2.00$; per $100, \$ 10.00$

QUAKER MAID-(Bill's Origination) See Page 29.

RED JACKET-(Bill's Origination) See Page 29.

REVUE-(Bill's Origination) Awarded First Prize by the Canadian Gladiolus Society at the annual exhibition 1924, for the best individual spike of Primulinus hybrid. Alrost too large to $\mathrm{be}$ classed generally with Primulinus hybrids, well expanded blooms with only slight hood but retaining all the airy gracefulness of the type. Very tall and straight with petals reflexed and slightly frilled. Added to this beauty in form the delicate coloring makes it a most desirable acxuisition. The center of the flower is pure Martius yellow, daintily flushed with Eosine pink on the tips of the petals. Quite early. Medium size bulbs recommended for large landscape plantings are $\$ 1.50$ per Doz. or $\$ 8.00$ per $100 \ldots \ldots \ldots \ldots \ldots \ldots \ldots$ $\ldots \ldots \ldots \ldots \ldots \ldots \ldots \ldots \ldots \ldots \ldots \ldots$. Each 25c; 3 for $65 e ;$ Doz. $\$ 2.50$; per 100, $\$ 12.00$

RICHMOND_(Bill's Origination) (New 1926) Large flowers of Spectrum red with

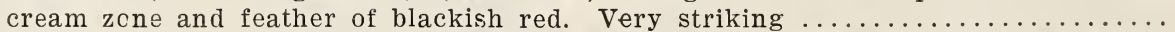
$\ldots \ldots \ldots \ldots \ldots \ldots \ldots \ldots \ldots \ldots$ Each 20c; 3 for 50c; Doz. $\$ 2.90 ;$ per 100, $\$ 10.00$

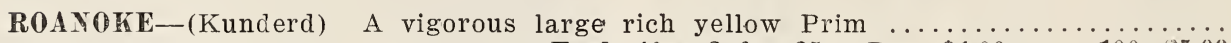
$\ldots \ldots \ldots \ldots \ldots \ldots \ldots \ldots \ldots \ldots \ldots$. Each 10c; 3 for 25c; Doz. $\$ 1.00$; per 100, \$5.00

ROBINHOOD-(Bill's Origination) See Page 29.

ROBCSTO-(Bill's Origination) See Page 29.

ROMANCE-(Kunderd) Hard to describe. Large Orange Salmon rose, red and yellow throat. Wine blue bordered petals .............Each 15c; 3 for $40 \mathrm{c}$ : Doz. \$1.50

ROMANTIC-(Bill's Origination) (New 1925) One of the extra good smoky ones. Strong grower, 16 to 18 buds, and 6 flowers open at once. Center is Coral pink, shading outward through old rose to Daphne red at the tips. Light yellow medial lines and feather of Acajou red on lower petals .. Each 25c; 3 for 65e: Doz. \$2.50

ROMULUS-(Bill's Origination) Very large, Jasper pink shaded to Jasper red and flaked with Spectrum red. A fine soft combination $\ldots \ldots \ldots \ldots \ldots \ldots \ldots \ldots \ldots \ldots . . . \ldots a c h$ 15c; 3 for $40 \mathrm{c}$; Doz. $\$ 1.50$; per $100, \$ 7.50$

ROSALIA-(Kunderd) (Prim.) Magnificent yellow blushed orange. Lower petals golden yellow. Another of the good ones ........ Each 10c; 3 for 250 Doz, $\$ 1.00$

ROSALIND-(Kunderd) (Ruffled) A massive ruffled variety of rich Analine red with deeper throat. One of the best ruffled ones ....Each $10 \mathrm{k} ; 3$ for $\$ 1.09$; Doz. $\$ 4.00$

ROSEMARY - (Bales) We are using Doc. Bales's own description and he knows. "White marked with fine hair lines and stipplings of Lavender ross, which becomes pure rose under artificial light. The markings are carried through the petals so that the back of the biossom looks the same as the front. Good sized blossoms carried on tall, straight, gracefully erect stems. Several open at one time." Introduced by Ole Doc Bales of the Triangle Farms, Circleville, Oh:o ......... $\ldots \ldots \ldots \ldots \ldots \ldots \ldots \ldots \ldots \ldots \ldots \ldots \ldots \ldots \ldots \ldots \ldots \ldots \ldots \ldots$ Each $\$ 1.00 ;$ Doz. $\$ 10.00$

ROTARY PINK-(Bill's Origination) See Page 29.

ROTARY WHITE-(Bill's Origination) See Page 29.

RUBELLA-(Bill's Origination) A deep velvet Amaranth purple. Wonderful rich shade. Nice, straight spikes with well placed fiorets. Petals are reflexed giving

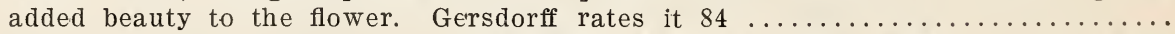
$\ldots \ldots \ldots \ldots \ldots \ldots \ldots \ldots \ldots \ldots \ldots . . \ldots a c h 20 c$; 3 for 50c; Doz. $\$ 2.00$; per 100, $\$ 10.00$ $\ldots \ldots \ldots \ldots \ldots \ldots \ldots \ldots \ldots \ldots \ldots$ Yedium size bulbs, Doz. $\$ 1.50 ;$ per $100, \$ 7.00$ 
SAL0ME-(Bill's Origination) (New 1925) Orange buff with Buff yellow throat. The color is so entrancing that it is simply irresistible. A Primulinus with a very wide hood ..................Each $20 \mathrm{c} ; 3$ for 50c; Doz。 $\$ 2.00$; per 100, $\$ 10.00$

SCARLET PRINCEPS-(Kunderd) A massive showy spike of large bright scarlet flowers. Many open at a time. A great improvement on the old Princeps. Quite

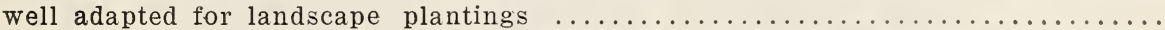
$\ldots . \ldots \ldots \ldots \ldots \ldots \ldots \ldots \ldots \ldots \ldots . .$. Each 10c; 3 for $25 c$; Doz. $\$ 1.00$; per 100, $\$ 6.00$

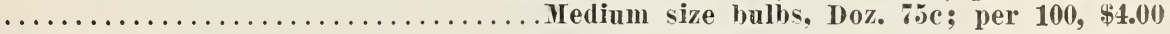

SCHWABEN-Strong grower with heavy spikes of yellow flowers. The most popular standard yellow .................Each je; 3 for 1bc; Doz. 50c; per 100, \$3.00

SERRATA-(Bill's Origination) See Page 29.

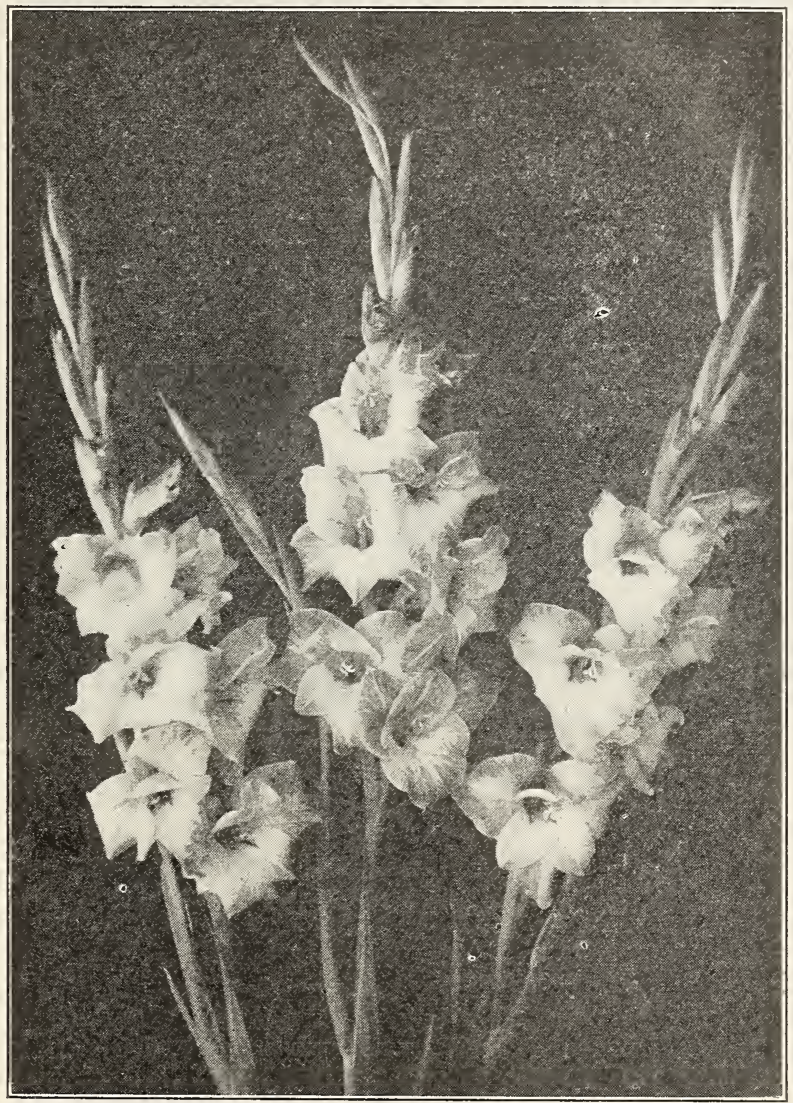

STA NLEY

STANLEY-(Bill's Origination) A Shrimp pink Primulinus hybrid shaded to Naples yellow in the throat. One of the tall growers opening many medium size flowers

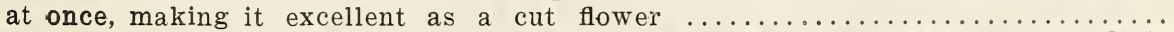
$\ldots \ldots \ldots \ldots \ldots \ldots \ldots \ldots \ldots \ldots \ldots . . \ldots a c h$ 10c; 3 for 2 osc; Doz. $\$ 1.00$; per $100, \$ 5.00$

"Debutante is a wonder both for size and color. I have never seen a gladiolus that
I thought so much of as this one."
C. E. BRADY. 


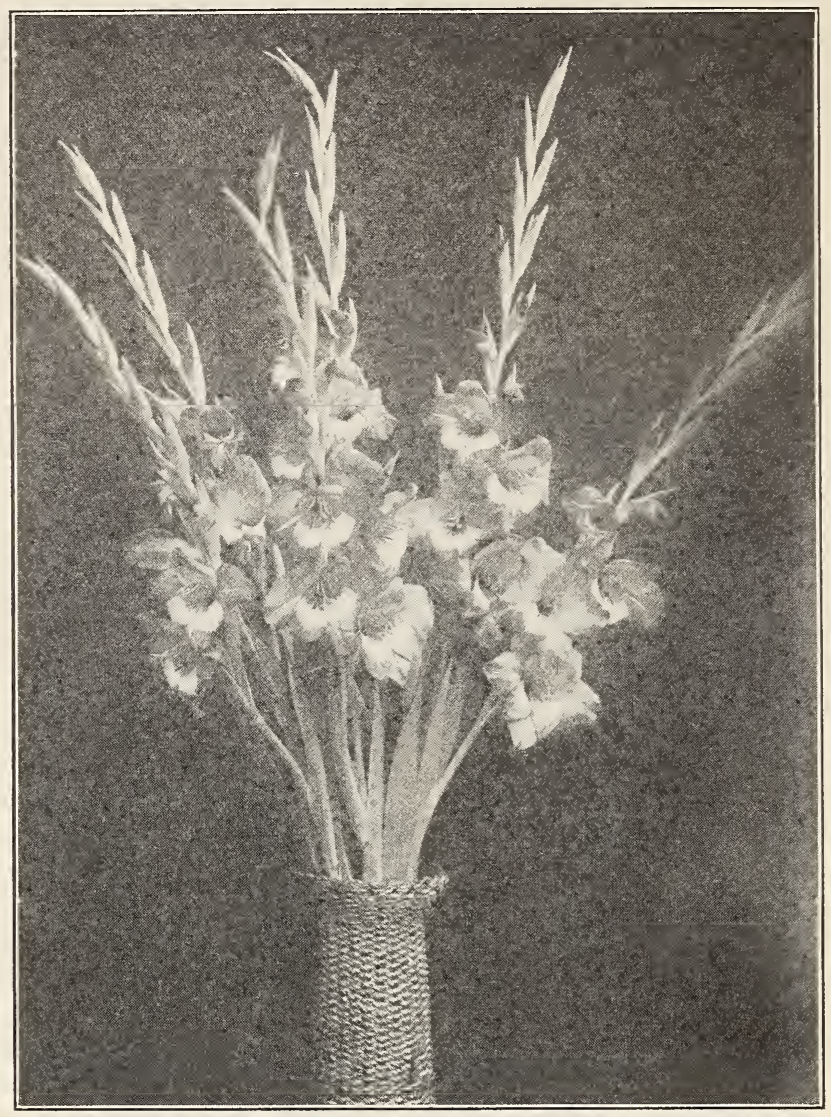

SWISS MAIDEN

SWISS MAIDEN-(Bill's Origination) (New 1926) Picture the Swiss Maiden with brilliant scarlet dress and apron of Sea Foam yellow. Then picture 6 to 8 of these maidens standing side by side and you have the idea $\ldots \ldots \ldots \ldots \ldots \ldots$

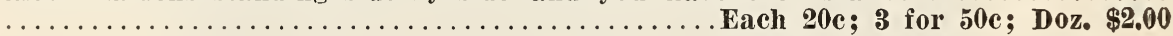

SIBYL-(Bill's Origination) Beautiful large cream flowers with tips of petals flaked Mallow pink. Strong grower and many flowers open at a time. Florists bought every flower the past season. SIBYL was awarded First Class Certificate by the

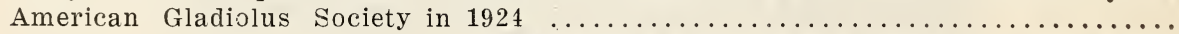

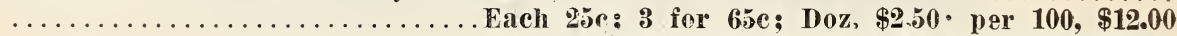
$\ldots \ldots \ldots \ldots \ldots \ldots \ldots \ldots \ldots \ldots \ldots \ldots \ldots \ldots \ldots \ldots \ldots$ Medium size bulbs, Doz. $\$ 1.50$; per $100, \$ 8.00$

SILVERTONE-(Bill's Origination) (New 1926) Yes, it has very much of a silver tone. Neat velvet carmine feather on a yeilow zone in the center. The balance of the flower is creamy white. Fine straight, tall spikes, long head and several open at once. Petals slightly frilled. A good one .......Each 2éc; 3 for 65c; Doz. \$2.50

SYOW BLOSSOM-(Bill's Origination) Pure white, good strong grower that will become a standard commercial white. Rated 86.3 as commercial flower ...........

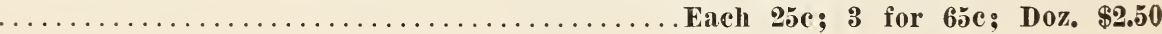


SONATA-(Bill's Origination) See rage 29.

SONNENBERG-(Bill's Origination) See Page 29.

SPLENDORRA-(Kunderd Very dark varety. almost wine black. Unusual and very

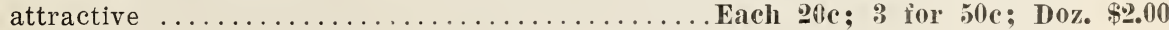

SPRING MAID-(Bill's Originaticn) Geranium pink with large striking creamy center. Tr:ple lines of Oxford red in the throat. A beauty and a winner .........

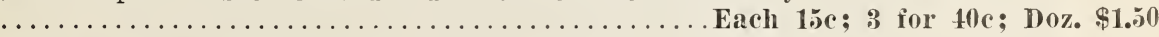

STARLIGHT-(Bill's Origination) See Page 31.

SUMMER DREAM-(Bill's Origination) See Page 31.

SYLVAY QUEEY-(Bill's Originat:on) See Page 31.

TAJ MAHAI-(Bill's Origination) See Page 31.

TANGERINE-(Bill's Origination) Tall graceful Primulinus of good size. Naples yellow, heavily flaked with Spinel red. A wonderful combination. Rated 90.5 by Gersdorff .................Each 10c; 3 for 2ǒc; Doz. $\$ 1.00 ;$ per 100, $\$$ อ̆.00

THE ARISTOCRAT-(Bill's Origination) See Page 31.

THE PELICAN-(Bill's Origination) No one can appreciate the peculiarly attractive style of The Pelican, without having seen it. The upper petal resembles a pelican's pouch inverted. The other two upper petals stand well apart while the three lower petals are small. The type is entirely new and extremely pleasing. Color is Jasper pink spread over a background of Chatenay pink. Two lower petals are Naples yellow. Rated $90 \%$ by Gersdorff $\ldots \ldots \ldots \ldots \ldots \ldots \ldots \ldots$ $\ldots \ldots \ldots \ldots \ldots \ldots \ldots \ldots \ldots \ldots \ldots$. Each $20 c$; 3 for $50 \mathrm{c}$; Doz. $\$ 2.00$; per $100, \$ 10.00$

'THEDA-(Bill's Origination) See Page 38.

TRIUMPHO-(Bill's Origination) See Page 31.

TROJANA-(Bill's Origination) Large open flowers of soft Geranium pink daintily flaked with Begonia rose. Bright scarlet line on pale yellow throat. Strong vigorous grower and excellent cut flower variety. One of the 12 winning the John C. Davis Cup in $1923 \ldots . . .$. Each $20 \mathrm{c} ; 3$ for 50c; Doz. $\$ 2.00$; per 100, $\$ 10.00$ Medium size bulbs, Doz. $\$ 1.50$; per $100, \$ 7.00$

TR00PER-(Bill's Origination) (New 1927) Very large Geranium pink Primulinus Grandiflorus with faint Ivory yellow throat. Extra strong, slender stem, very

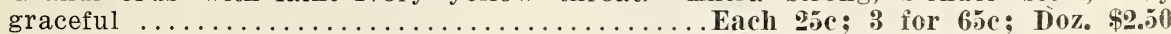

VICTOR-(Bill's Origination) (See Page 31.

VINACEA-(Bill's Origination) (New 1927) Ridgway's chart calls the color Vinaceous shaded deeper and lightly flaked with Madder brown. Edges of petals are Smoky blue. A heavy feather of Amaranth purple bordered with a zone of light Coral red. A magnificent spike with 18 to 20 buds and 8 flowers open at once. Petals are very thick, waved and reflexed .............Each 25e; 3 ror 65c; Doz. \$2.50

VON SION-(Bill's Origination) A pure deep yellow with bronze throat lines. Color similar to Von Sion Narcissus. Slight frill on petals. Short growth and medium size flowers make it useful for landscape work

$\ldots \ldots \ldots \ldots \ldots \ldots \ldots \ldots \ldots \ldots \ldots \ldots \ldots \ldots \ldots \ldots \ldots$ Each 15c; 3 for $40 \mathrm{c} ;$ Doz. $\$ 1 . \mathrm{o} 0$; per 100, \$7.50

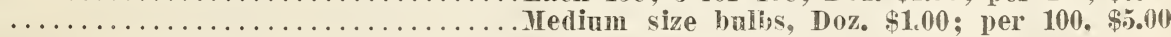

WARRIOR-(Bill's Origination) See Page 31.

WENDY-(Bill's Origination) (New 1925) A neat little Primulinus named for Wendy of "Peter Pan" fame. Very early, hooded, winged and frilled. Opens several delicate flesh flowers, shaded to Martius yellow in center. Fine for artistic house decoration ...................Each 10c; \$ for 2ø้c; Doz. $\$ 1.00$; per 100, $\$ 5.00$ 


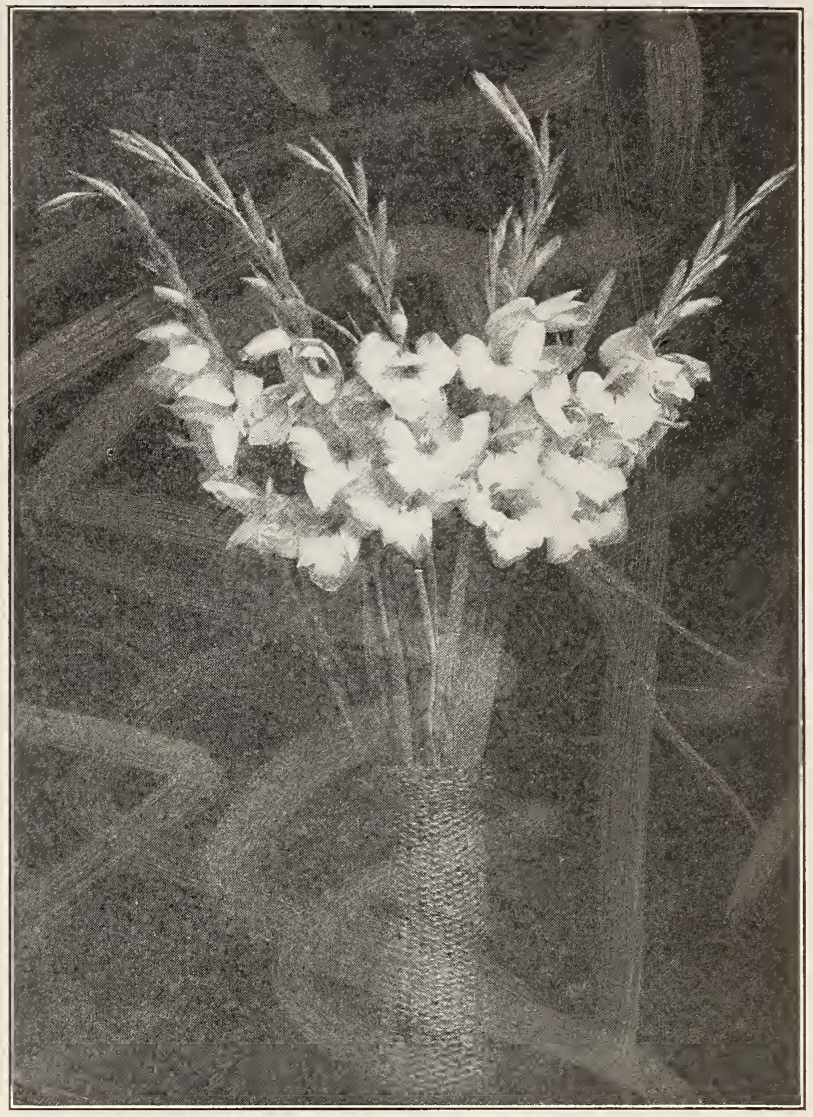

THEDA

THEDA-(Bill's Origination) EARLIER THAN HALLEY. GREAT FOR FORCING! Large open flowers, well placed on tall stems. Most delicate Shrimp pink gradually blending to soft Pinard yellow in the throat with Pansy violet lines on the lower petals. Retail florists use it for fancy trade. Garden enthusiasts rave over it.

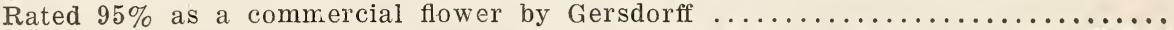

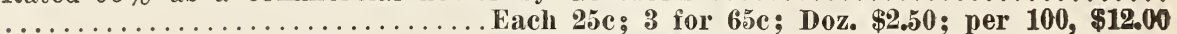
Medium size bulbs, Doz. $\$ 1.50$; per $100, \$ 8.00$

WHITE 0RCHID-(Bill's Origination) See Page 31.

WHITE PREMIER-(Bill's Origination) See Page 31.

ZEALOT-(Bill's Origination) (Prim.) A velvet scarlet with yellow medial dashes in center. Very striking and attracts much attention. Winner at the A. G. S. Show in 1925 for Best Scarlet Prim... Each 10c; 3 for 25c; Doz. $\$ 1.00$; per 100, $\$ 5.00$

"Last summer I bought a few gladiolus bulbs from you and I want to tell you that I was delighted with them. Every bulb bloomed, some two spikes of flowers. and when I took them up this fall were in fine condition. A neighbor saw them in bloom and admired them very much, said she would like some, so I am ordering some for hor christmas gift." MISS MARY B. RUTHERFORD, Pa. 


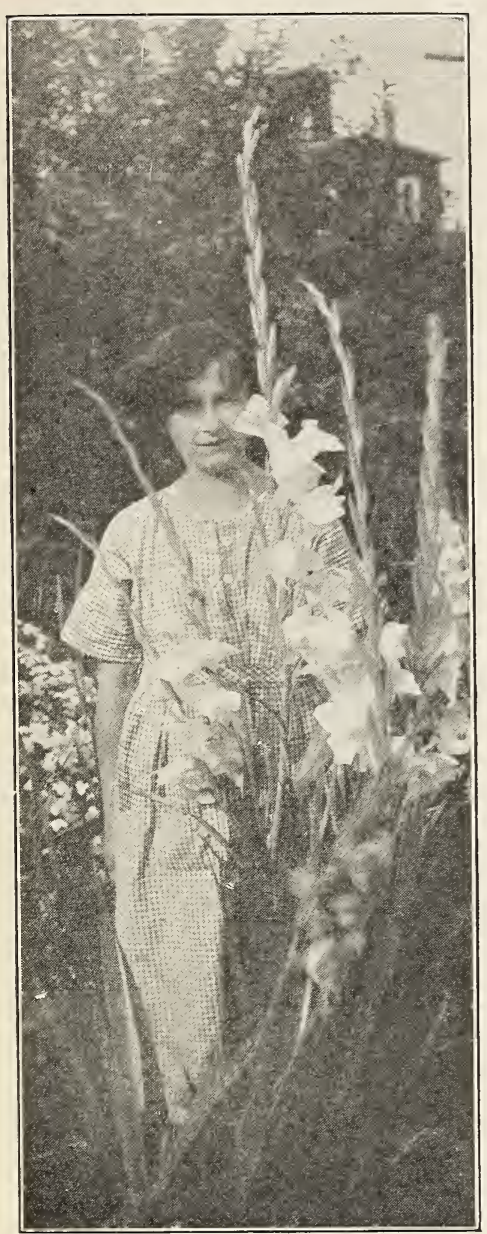

In the Garden Six Feet Tall

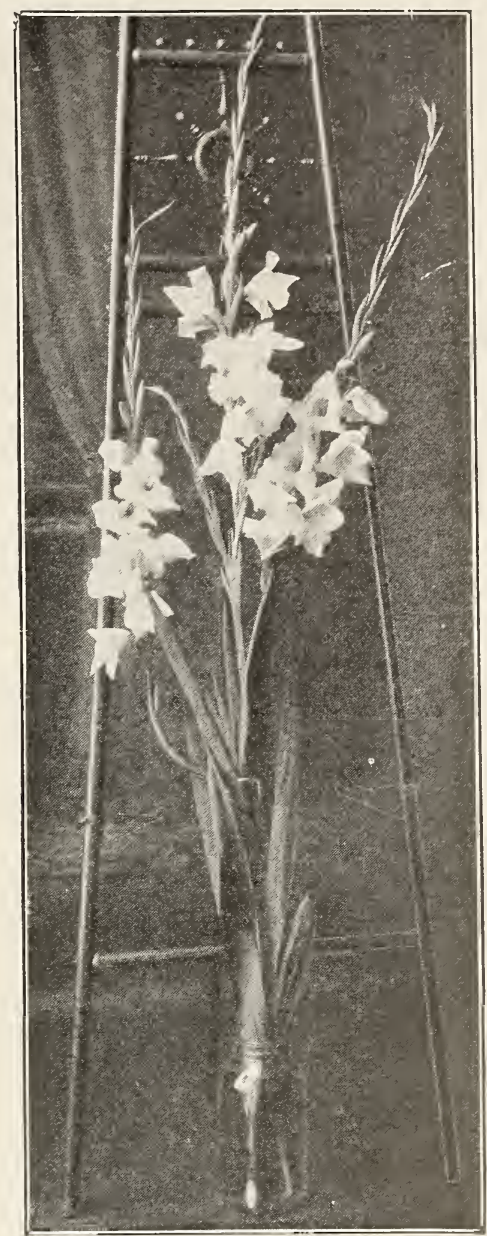

After Cutting Four to Five Feet

\section{VA NITY}

(Bill's Origination)

Delicate LaFrance Pink flushed over cream ground. Very large flowers of airy graceful type with slightly reflexed petals.

Unsurpassed for large baskets.

\section{Prize Winner}

Won first prize at A. G. S. Show in N. Y. City for handsomest floor basket.

\section{Money Maker}

The sensation of the New York Wholesale cut flower market.

Awarded First Class Certificate by the American Gladiolus Society in 1924.

Strong vigorous grower. ......... Each 25c; 3 for 65c; Doz. $\$ 2.50$; per 100, $\$ 12.00$ Medium Size bulhs, Doz. $\$ 1.50$; per $100, \$ 8.00$ 


\title{
Make Your Own Collections
}

\author{
USING THESE
}

\section{SPECIAL DISCOUNTS}

If your order amounts to $\$ 5 . C 0$ or more, you are entitled to the reductions as shown in schedule beiow. These discounts apply on all orders made up from the General List and Connoisseur Section, but they do not apply to any Special Offers as listed on Pages $32, \angle 0$ and 41 .

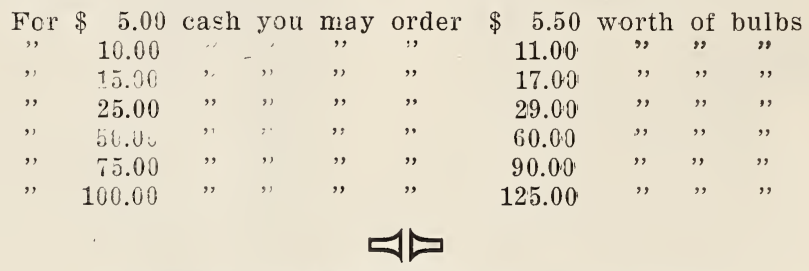

\section{GLORIOUS MIXTURE (Special Offer)}

This mixture is made up of all types and colors. Bulbs of many high-priced varieties of which we have a surplus are included. In lots of 100 we guarantee to send at least 20 varieties.

Large Bulbs, 25 for $\$ 1.00$; per $100, \$ 3.00$

Medium Size, 40 for $\$ 1.00$; per $100, \$ 2.00$

\section{ロ•}

\section{PRIMULINUS MIXTURE (Special Offer)}

All the soft shades of the beautiful dainty Primulinus type. This mixture contains many of the best varieties grown.

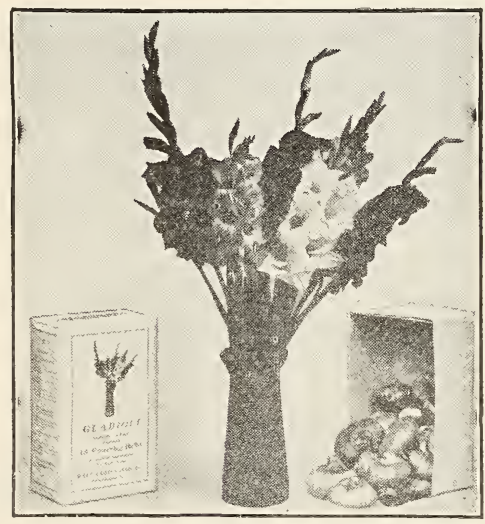

\section{HANDSOME GIFT BOXES SPECIAL \& 1 OFFER 18 WONDERFUL GLADIOLUS}

Not Labeled

Our Selection

Selected from Bill's Prize Winners-Guaranteed Quality 


\section{SPECIAL OFFER NO. 23}

12 Good Varieties, All Labaled Separately, for $\$ 1.0$ ? Our selection, catalog value, $\$ 1.50$, or more.

SPECIAL OFFER NO. 24

24 Good Varieties, All Labeled Separately, for $\$ 2.00$ Our selection, catalog value, $\$ 3.00$, or more.

SPECIAL OFFER NO. 25

BILI'S BEST BARGAIY

Twenty Varieties, Listed Below, Correctly Labeled, for $\$ 2.00$. Catalog value, $\$ 3.50$.

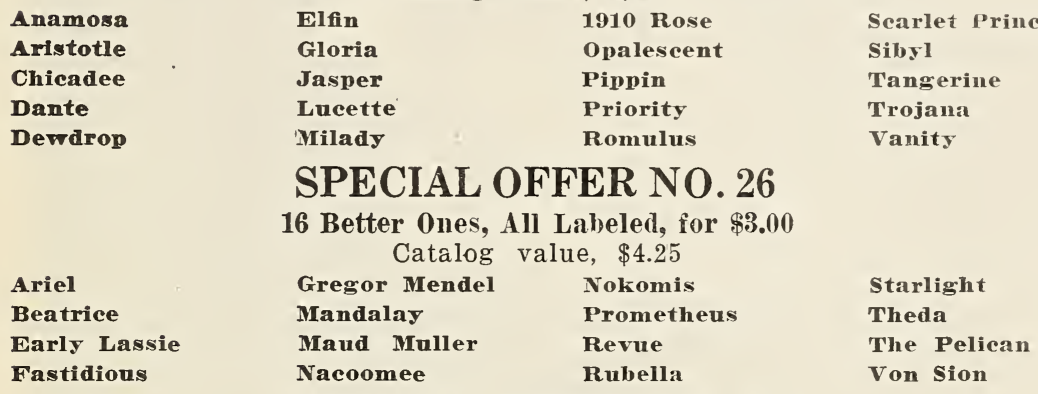

SPECIAL OFFER NO. 27

High Quality Dozen Listed Below, All Labeled, for $\$ 5.00$

Catalog value, $\$ 7.50$

$\begin{array}{llll}\text { Broadelbin } & \begin{array}{l}\text { Hopewell White } \\ \text { Chameleon }\end{array} & \begin{array}{l}\text { Olympiad } \\ \text { Humdinger }\end{array} & \begin{array}{l}\text { Robinhood } \\ \text { Triumpho } \\ \text { Matriador }\end{array} \\ \text { Quaker Maid } & \text { Warrior }\end{array}$

SPECIAL OFFER NO. 28

Seren Rare Varieties, Listed Below, All Labeled, for $\$ 15.00$

Catalog value, $\$ 20.00$

$\begin{array}{llll}\text { Break O' Day } & \text { Cleopatra } & \text { Halcyon } & \text { The Aristocrat } \\ \text { Canandaigua Red } & \text { Gladdie Boy } & \text { Serrata } & \end{array}$

SPECIAL OFFER NO. 29

Six New Super Glads, All Labeled, for $\$ 50.00$

Catalog value, $\$ 65.00$.

Creatore

Fleetwood

$\begin{array}{ll}\text { Fort Sumter } & \text { Sonnenberg } \\ \text { Oh Boy } & \text { White Orchid }\end{array}$

\section{SPECIAL OFFER NO. 30}

\section{Unnamed Seedlings}

I find we have hundreds of unnamed seedling varieties worthy of a place in any high class collection. It is out of the question to name all of them. After destroying all the poor ones, I am going to use the others to make up special offers for those who want some new faces in their gardens. Some of the varieties I include in these collections will be given names and a place in our catalog in a year or so. They will be tagged by number so you can request information later as to whether they have been named. If you are particularly fond of some of them, write us your description of them, giving the good points as well as defects, and let us have your suggestion as to a suitable name. If we accept the name, we will send you 12 bulbs of the variety gratis.

We are going to pack 12 varieties of these unnamed seedlings in a nice box, all labeled by number, and send them to you postpaid for $\$ 5.00$ a box. We can supply you with several boxes without duplicating any variety. 


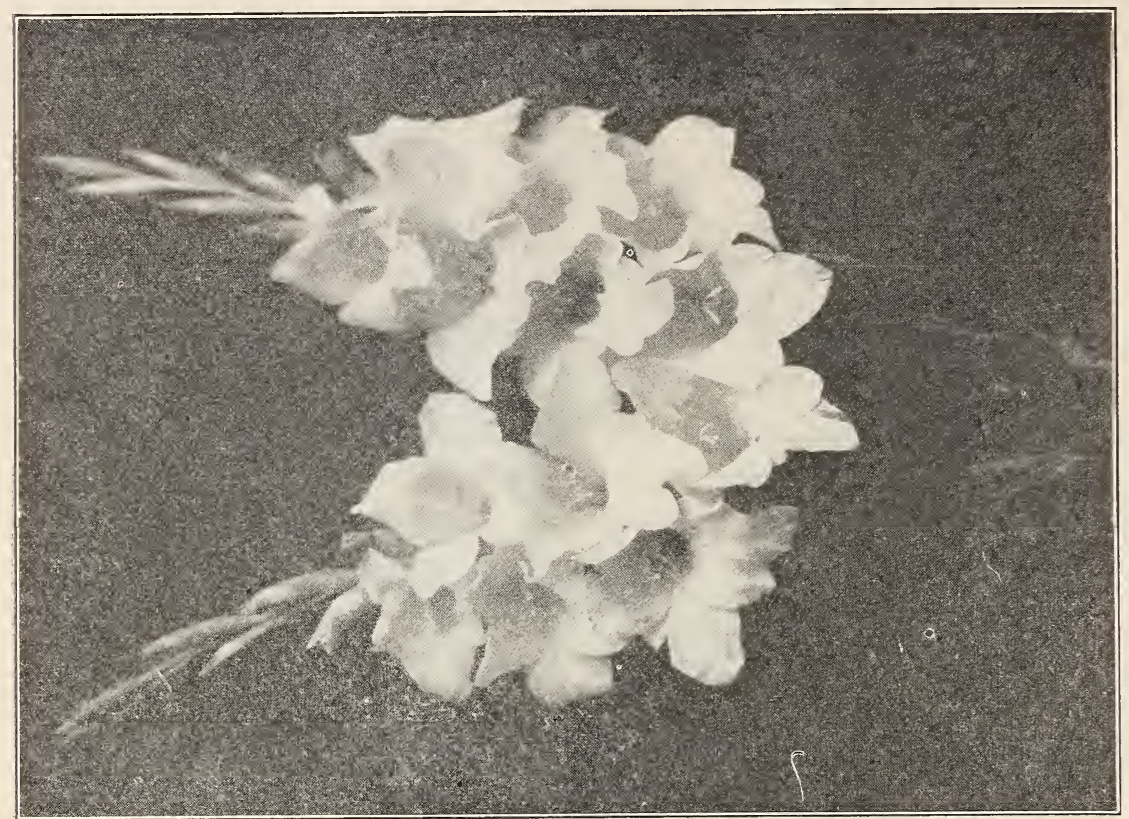

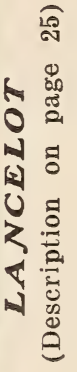

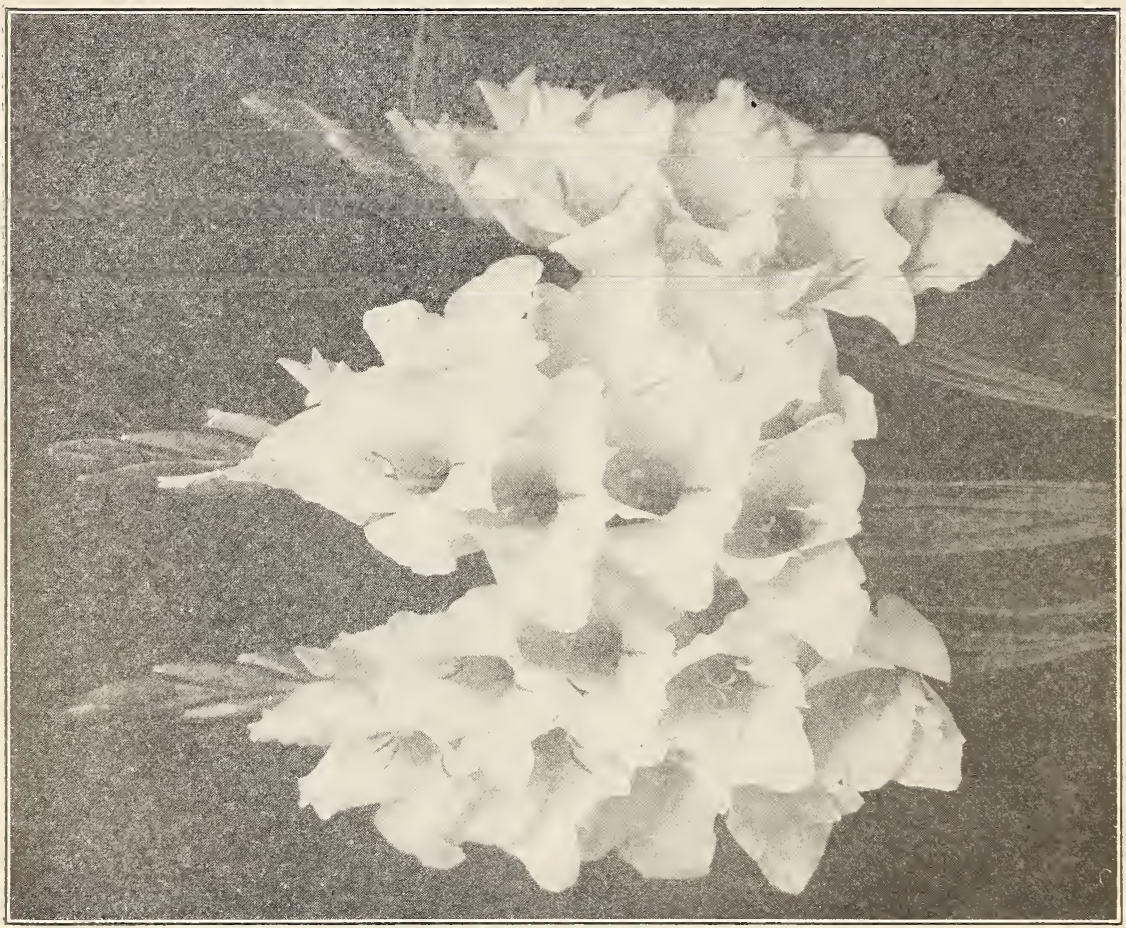

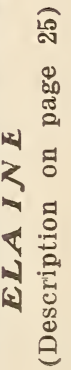




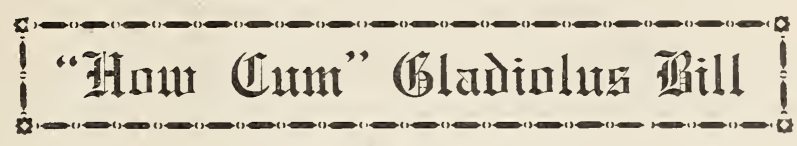

Once upon a time (as all stories niust start) there lived in a flat a man of middle age who received a check once every so often from a large corporation. To make sure that these checks would keep coming it was necessary that he apply himself diligently to the supervision of the corporation's branch office and factory. Now supervision starts somewhere just below the chin and continues upward to the proverbial bald spot. While supervision is supposed to control innumerable difficulties it fails when called upon to keep a leather belt from shrinking. So it happened when the last hole was punched in the very end of the belt supporting a part of this man's quite necessary wearing apparel, then he realized something definite must be done without delay.

No, a standard golf course cou!d not fit in that $2 \times 4$ back yard, but he did find that the hardware store handled a line of.close quarters golf sticks, known as hoes, forks, rakes, trowels and dibbles. His best friend, who always called him by that most familiar of all names "Bill," chanced to meet him with the new assortment of irons and shouted, "Hey, Bill, what's the big idea?" Bill, promptly pulled from his pocket the instruction book handed to him by the hardware man. This book not only gave all the rules of the game, but prices as well of such necessary articles as seeds, plants, bulbs and fertilizers. "Oh," says Al, "who is going to do the work? Where is the farm." A bit pe'eved, Bill replied "None o' your bizness, watch me."

Sure enough, Al did watch him and the second summer he saw that little back yard a blaze of glory. "What you call them things, Bill?" he inquired. "Gladiolus," says Bill, "and I am making some rew ones." From that time on Al always called him Gladiolus Bill. Others took it up and he soon became widely known under that title. Then came much reading and study of the laws governing heredity, topped off later with a course at Cornell for more information.

In a very short time it was necessary to secure more space and finally Bill decided to do without any more of those corporation checks. The new Glads that Bill had made became so popular that the business grew up almost over night and in 1926 under the corporate name of "Bill's Glad Farms" he had twenty-eight acres devoted entirely to Gladiolus. To get even with Al he has named a very wonderful variety Allen V. Bunce.

Thres things have contributed to this wonderful development of a back yard hobby. First, a love for growing things. Second, the production of varieties of real merit with a frank honest description of them. Third, the use of a trade name that you can remember, as few of you would have patronized Wm. Purple as freely as you have Gladiolus Bill.

\section{WE THANK YOU}

We would be grateful to you if you sent us the names of your friends whom you know to be interested in Glads. Perhaps, too, we might slip something extra in with your order if you did this. Why not try it? 
BILL'S GLAD FARMIS, Inc.

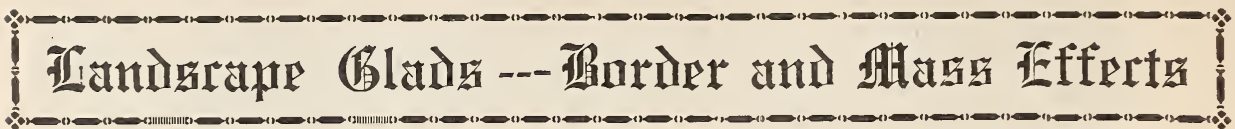

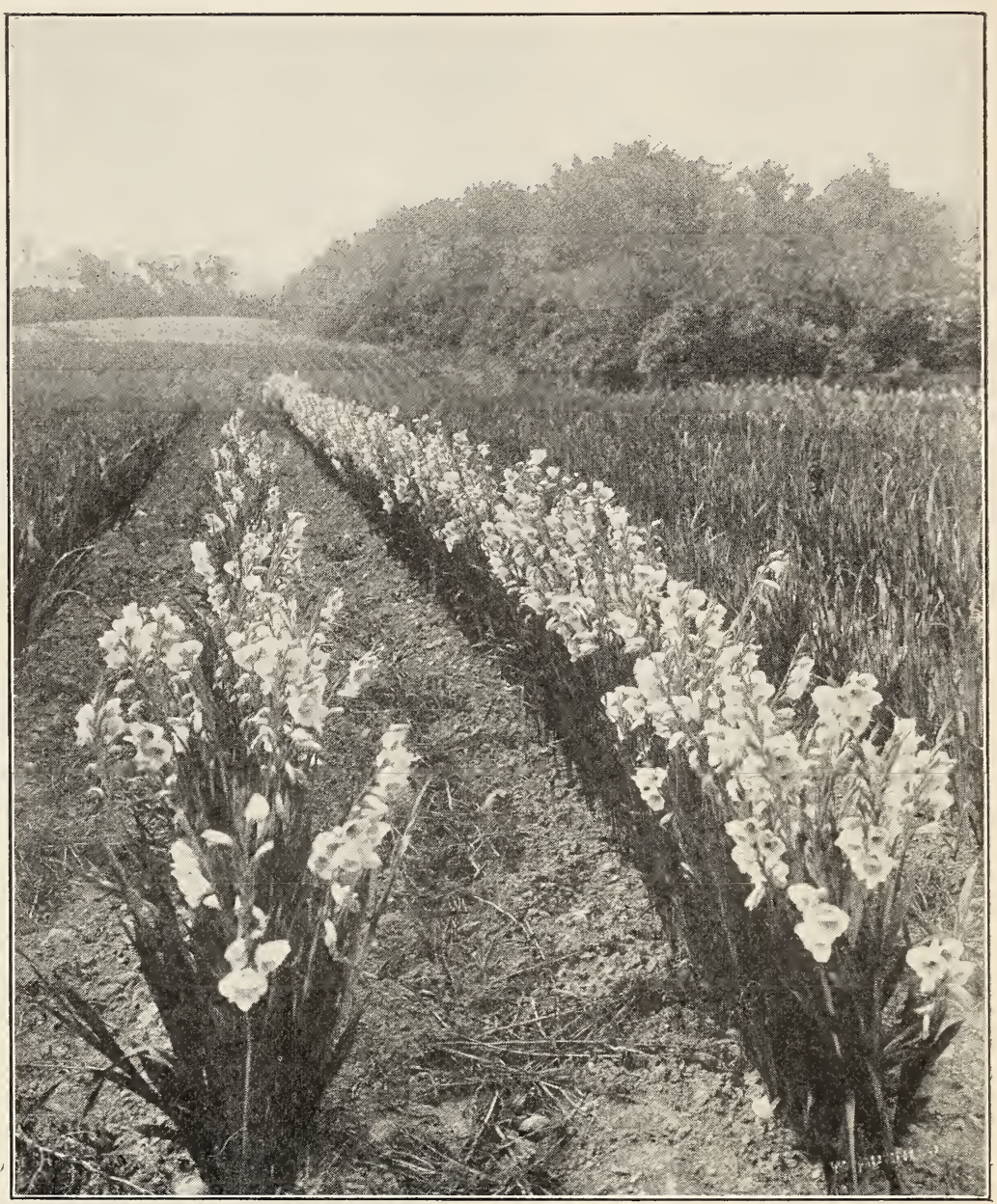

Recommended as best for Landscape Plantings.

Albion - Salmon pink

Alice Tiplady - Orange saffron

Ariel - Cream white

Carmine Kid - Carmine

Chicadee - Eosine pink

Dante - Mallow purple
Dewdrop - Light yellow

Freckles - Orange salmon

Lucette - White

1910 Rose - Rose

Revue - Flushed pink

Scarlet Princeps - Scarlet

Von Sion - Deep yellow 


\section{"THE GLADIOLUS BOOK"}

\section{By McLean, Fischer and Clarke, $\$$ Jे.00 $^{\circ}$}

A practical and comprehensive review of the entire Gladiolus family in all its numerous ramifications. It tells about the races and types of the different breeders, what they have worked with and how the different species have come to influence the different strains. The cultural treatment is of the most practical kind. In fact, the volume is just what it says-"The Book of the Gladiolus"-illustrated with 24 pages of half tone and black and white and four pages of color plates showing the history and evolution of the Gladiolus. This is the book all Gladiolus lovers have been waiting for.

\section{SOME VERY PRACTICAL GARDEN BOOKS. "THE GARDENER"}

By L. H. Bailey-IIIustrated, 260 pages, $\$ 2.00$

Simple directions for growing the common fruits, vegetables and flowers in the garden and about the house. An accurate gardening guide, arranged alphabetically for handy reference.

\section{"THE PRACTICAL FLOWER GARDEN"}

By Helena R. Ely-Illustrated, 216 pages, $\$ 2.50$

Combines skilful entertainment with practical discussions on color arrangement plantings, life cycles from seed to flower, landscape treatment and use of fertilizers.

\section{DESIGN OF SMALL PROPERTIES}

By M. E. Bottomley-Illustrated, 265 pages, $\$ 3.50$

More than 50 examples of layouts for the general development of small city and country homes are presented. Gives descriptive lists of trees, shrubs, vines, and flowers with directions for their planting and maintenance.

\section{USE THIS FOR YOUR GLADS:}

\section{- THE IMPROVED METAL TREE LABEL -}

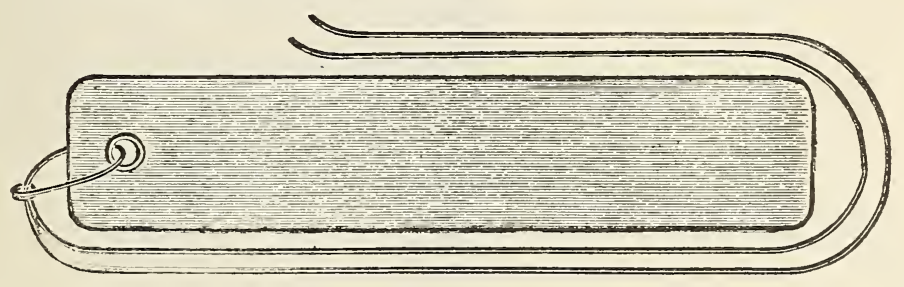

AN INDESTRUCTIBLE LABEL, For use on Trees, Bulbs, Shrubs, Vines and Transplants. Made of Copper Alloy or Zinc, impervious to weather conditions, and so constructed that the wire Cannot Cut through the Metal,

- Lay the label on a pad, [folded newspaper] writing with a stylus or hard pencil. Stylus supplied, no charge, with every box of 100 labels. -
SIMPIE
IEGIBIE
PERMIAINENT

No. 1 Size-3/4" x 31/2", 25 for 60c; per 100, $\$ 2.00$.

Order them packed with your bulbs.

\section{GARDEN LABELS}

Painted 3/" x 8" 1 cent each

This is the best thing available for a temporary marker. Simply write names on the label with a pencil. Packed with your bulb order. 
BILL'S GLAD FARIMIS, Inc.

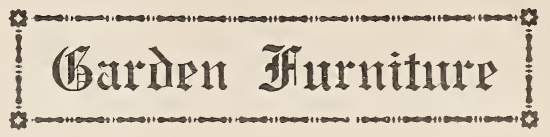

Each piece is constructed of select grade gulf cypress dressed four sides. Because cypress has been known to stand for years without rotting, it has come to be known as the "Wood Eternal".

Our garden furniture is properly primed and then finished with high grade lacquer, making a beautiful and permanent finish which is easily cleaned with soap and water or with gasoline. This is an unusual and weather resisting finish.

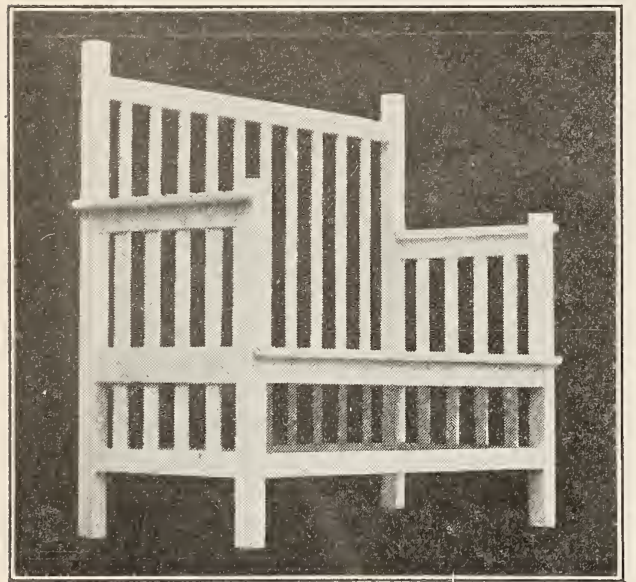

No. 502. Here is a very attractive and substantial bench, seating two comfortably. We call it the "Colonial".

The seat measures 20 inches deep by 4 feet long. The seat boards are spaced $1 / 4$ inch apart which allows for the extremes in weather. Corner posts are $2^{\prime \prime} \times 2^{\prime \prime}$.

The slats in the back and sides are mortised in place and no nails are used for this purpose. All cypress. It can be moved easily about the lawn or garden as desired. Price, oil primed, $\$ 25.00$; white, $\$ 31.00$.

No. 502

No. 511. The Garden Chair is built of the same stock and material as the No. 502 Bench. Chair measures 24 inches wide by 20 inches deep. You will find it very comfortable. The bottom boards are spaced $1 / 4$ inch apart. Price, oil primed, $\$ 19.75$; finished white, $\$ 22.50$.

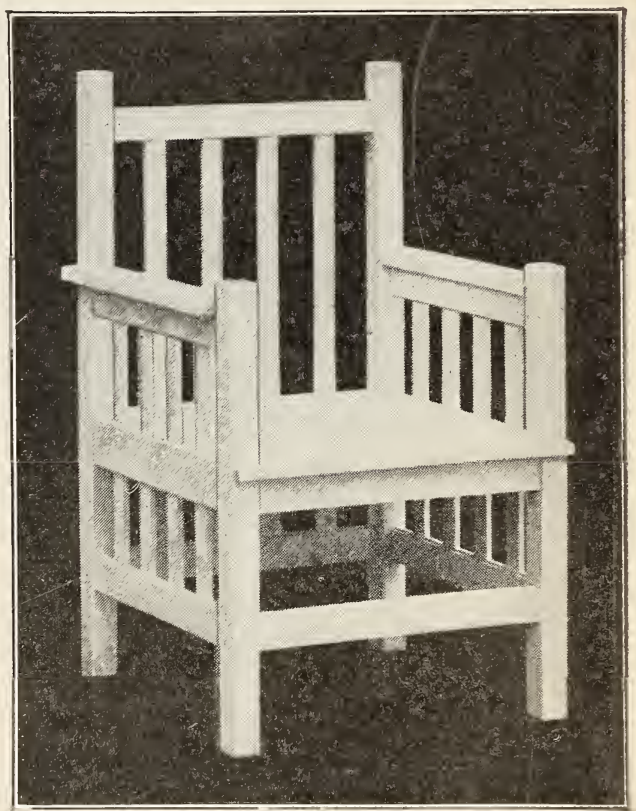

No. 511 


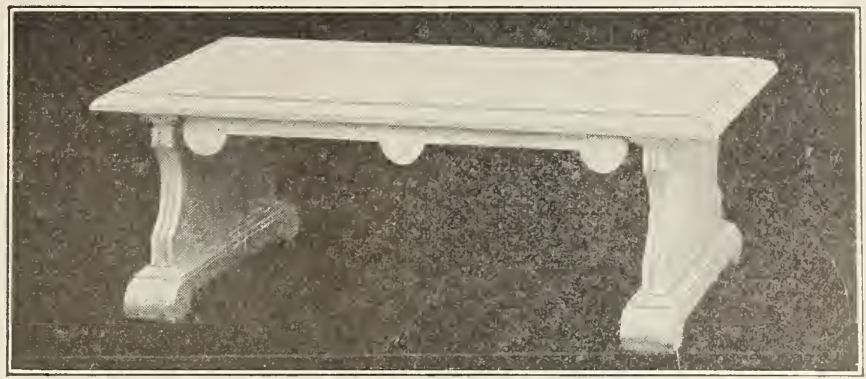

No. 504

No. 504. This Grecian Bench is made entirely of cypress. The lines are exceptionally graceful. The workmanship so fine that after receiving our all weather finish, it resembles a piece of marble. It is 4 feet long by 2 feet wide. Price, oil primed, $\$ 22.00$; finished white, $\$ 25.00$.

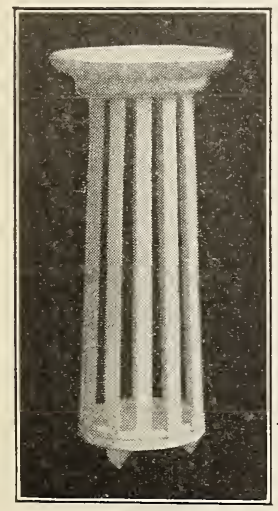

Yo. 505

No. 505. Birdbath. The pedestal is of cypress, finished white. An ivy or other vine can be trained on this with beautiful effect. Bird Bath is of brown porcelain. Simply lift it off for cleaning. Easy to keep clean because of glazed finish. Price complete in white, $\$ 12.00$.

\section{GUARANTEE}

We guarantee our products to be as represented both in respect to workmanship. and materials used.

We are not responsible for damage in transit, as all goods are delivered to carrier well packed and in good condition and are so accepted. charges.

Be sure to examine for any evidence of careless handling before paying freight

Prices include crating and are F. O. B. Canandaigua, N. Y. Goods are packed in such a manner that they take the lowest freight rate for this class and the charges are found to be very little. Boxes.

Ask for our complete 36-page catalog of Garden Furniture, Trellises and Flower. 
BILL'S GIAD FARIMS, Inc.
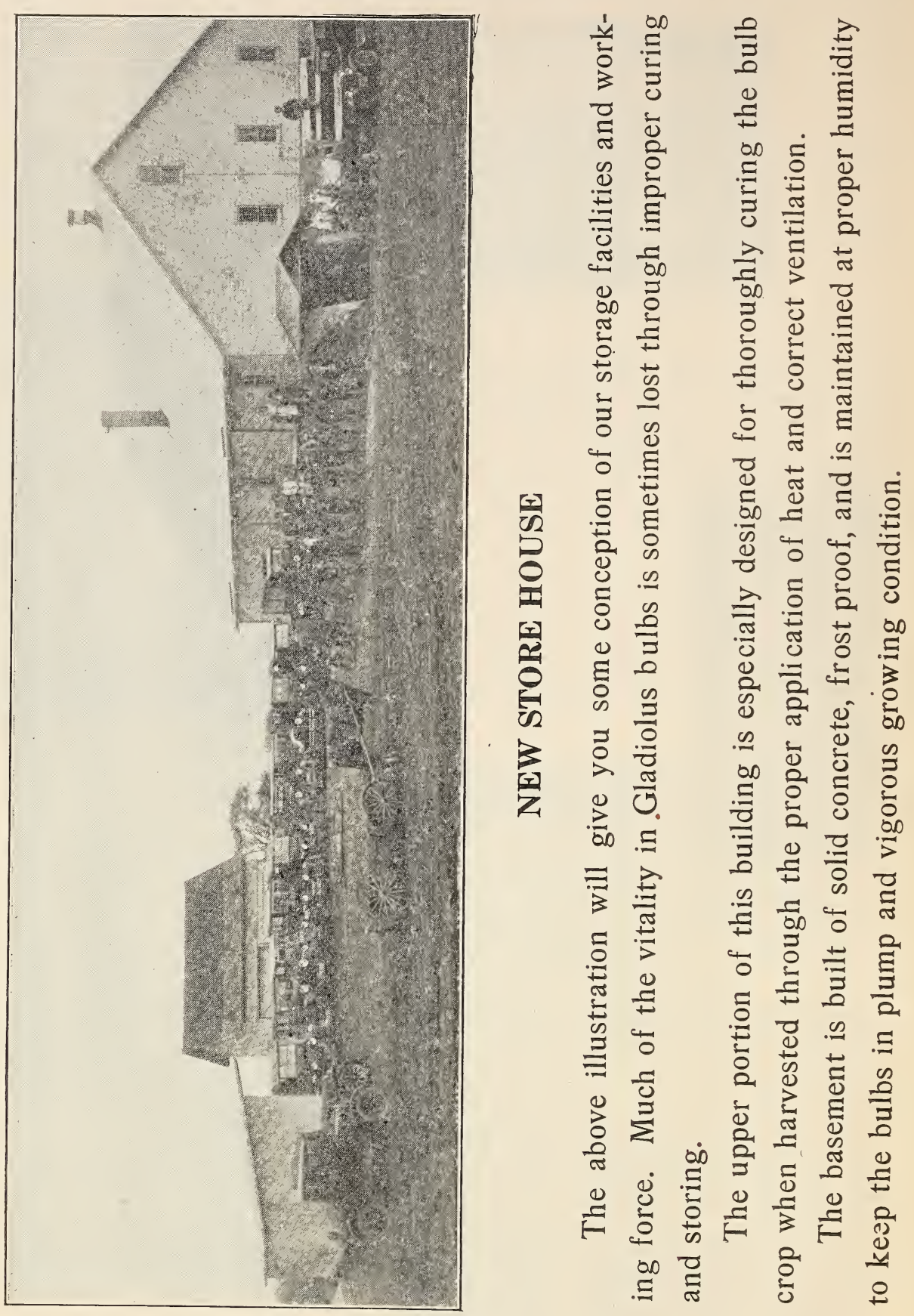


\section{CULTURAL DIRECTIONS}

Unpack the bulbs as soon as received and keep in a cool dry cellar until ready to plant.

Any good garden soil will answer but do not use any fresh manure in the spring. If fertilizer is required apply barnyard manure the previous fall or use vigoro in the spring.

WHEN TO PLANT: In central New York the best time to plant is from May 1st to 15 th, when the weather has become settled. If you are farther south plant earlier. A good plan is to plant when Maple trees begin to open their leaves. For later flowers you may plant at various periods up to the 4 th of July.

HOW TO PLANT: The general method is to plant in rows anywhere from $11 / 2$ feet to 4 feet apart, depending on the method of cultivation to be employed. Dig a trench 5 inches deep and 2 inches wide at the bottom. Place the bulbs on the bottom of the trench, 3 inches to 5 inches apart, and then fill the trench level full with soil. Deep planting and close planting buth help the plants to stand erect at blooming time. We never have to tie them to stakes in our fields.

WHERE TO PLANT: They will bloom if planted most anywhere. They will not be at their best if roots from large trees penetrate the ground where they are located. Remember that the roots of trees reach out further than the branches. Neither will they be very happy planted against the house or porch. Out in the garden or in special beds is the place where they will flaunt their beauty to perfection. Plenty of air and sunshine makes them strong and sturdy.

WATER: If you wish you may water them in dry seasons but water thoroughly. Dig into the soil after you think they are soaked and if the soil is not wet 5 inches give them still more water. Don't sprinkle a little every evening but give them a thorough soaking and then let them alone for a week.

CULTIVATION: Do it after every rain or watering. Keep the surface loose and don't let the weeds live on the moisture which belongs to the Glads.

DIGGING AND STORING: As the Maples begin to lose their leaves, lift the bulbs, cut the top off close to the bulb and expose to sunshine for two or three days. Then store in a cool dry cellar, $40^{\circ}$ is best. In about three weeks you can remove the old bulb and roots with ease. Look your stock over and order more bulbs from "Gladiolus Bill" for next season. Also send him a Christmas bulb order for that friend who admired your flowers.

BLOOMING TIME: Go out in the garden early each morning and see the new ones with the dew on them. The fresh flowers always open early in the morning. The buds never open after noon. If you want them for house decoration cut them in the forenoon when two or more flowers have opened. Put in vases or baskets with fresh cool water. Give fresh water every morning, remove wilted flowers and cut about $1 / 2$ inch off the stem. Given this care, every bud on the stalk will open in the house. They often last a week or more after they are cut. We hope you will mark the names of varieties when you plant them. so that you can call them by name when you see them. Give them a personality and you will enjoy them twice as much. Before you forget it, select those you like best and send in a new order at once for more of those varieties.

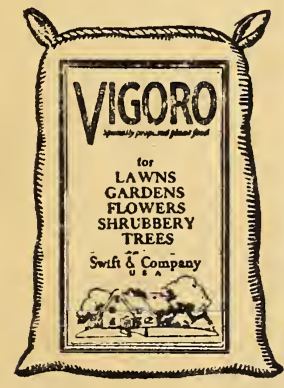

VIGORO is an extra strong concentrated fertilizer product. DO NOT USE TOO MUCH as you will surely burn your plants. Follow directions explicitly.

Neat $5 \mathrm{lb}$. package $\$ .75$ post paid anywhere East of Illinois and North of Tennessee. and South Carolina.

25 lb. bag- $\$ 1.75 ; 50$ lb. bag- $\$ 3.00 ; 100 \mathrm{lb}$; bag- $\$ 5.00$ by express collect.

Five lbs. will cover 100 to 200 sq. ft. Mix it thoroughly with the soil or use as a top dressing.

CAUTION: Do not let it come in direct contact with Bulbs, roots, siems or foliage.

Send the order to

BILL'S GLAD FARIIS, Inc.

Originators and Growers of Glorious Glads Canandaigua, N. Y. 
